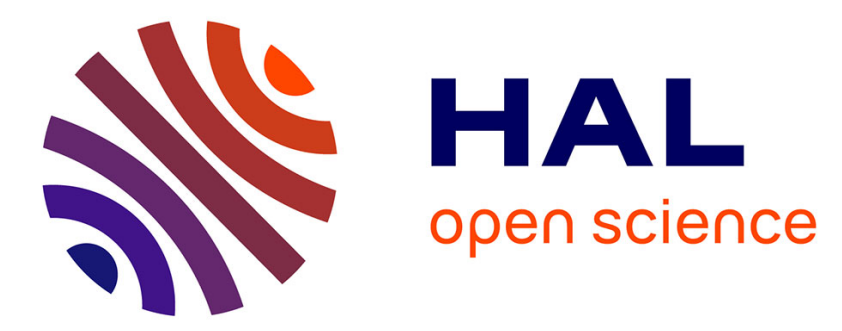

\title{
The subduction plate interface: rock record and mechanical coupling (from long to short timescales)
}

Philippe Agard, A. Plunder, Samuel Angiboust, Guillaume Bonnet, J. Ruh

\section{To cite this version:}

Philippe Agard, A. Plunder, Samuel Angiboust, Guillaume Bonnet, J. Ruh. The subduction plate interface: rock record and mechanical coupling (from long to short timescales). Lithos, 2018, 320-321, pp.537-566. 10.1016/j.lithos.2018.09.029 . hal-02307355

\section{HAL Id: hal-02307355 \\ https://hal.sorbonne-universite.fr/hal-02307355}

Submitted on 7 Oct 2019

HAL is a multi-disciplinary open access archive for the deposit and dissemination of scientific research documents, whether they are published or not. The documents may come from teaching and research institutions in France or abroad, or from public or private research centers.
L'archive ouverte pluridisciplinaire HAL, est destinée au dépôt et à la diffusion de documents scientifiques de niveau recherche, publiés ou non, émanant des établissements d'enseignement et de recherche français ou étrangers, des laboratoires publics ou privés. 


\title{
The subduction plate interface: rock record and mechanical coupling (from long to short timescales)
}

\author{
P. Agard ${ }^{\text {a,* }}$, A. Plunder ${ }^{\text {a }}$, S. Angiboust ${ }^{\text {b }}$, G. Bonnet ${ }^{\mathrm{a}}$, J. Ruh ${ }^{\mathrm{a}, \mathrm{c}}$ \\ a Sorbonne Université, CNRS-INSU, Institut des Sciences de la Terre Paris, ISTeP UMR 7193, F-75005 Paris, France \\ b Institut de Physique du Globe de Paris, Sorbonne Paris Cité, Univ. Paris Diderot, CNRS,F-75005 Paris, France \\ ${ }^{\mathrm{c}}$ Institute of Earth Science Jaume Almera, ICTJA-CSIC, Barcelona, Spain
}

Keywords:

Subduction

Plate interface

Mechanical coupling

Slab dynamics

Mantle wedge

Eclogite

Blueschist

Oceanic lithosphere
Short- and long-term processes at or close to the subduction plate interface (e.g.,mineral transformations, fluid release, seismicity and more generally deformation) might be more closely related than previously thought. Increasing evidence from the fossil rock record suggests that some episodes of their long geological evolution match or are close to timescales of the seismic cycle. This contribution uses rocks recovered (episodically) from subduction zones, together with insights from thermomechanical modelling, to provide a new dynamic vision of the nature, structure and properties of the plate interface and to bridge the gap between the mechanical behavior of active subduction zones (e.g.,coupling inferred from geophysical monitoring) and fossil ones (e.g., coupling required to detach and recover subducted slab fragments).

Based on critical observations and an exhaustive compilation of worldwide subducted oceanic units (for which the presence near the plate interface, rock types, pressure, temperature, $\mathrm{T} / \mathrm{P}$ gradients, thickness and timing of detachment can be assessed), the present study demonstrates how long-term mechanical coupling exerts a key control on detachment from the slab and potential rock recovery. Critical assessment of rock T/P characteristics indicates that these fragments can indeed be used as natural probes and provide reliable information on subduction interface dynamics down to $\sim 2.8 \mathrm{GPa}$. Rock clusters are identified at depths of 30, 55-60 and $80 \mathrm{~km}$, with some differences between rock types. Data also reveal a first-order evolution with subduction cooling (in the first $\sim 5 \mathrm{Myr}$ ), which is interpreted as reflecting a systematic trend from strong to weak mechanical coupling, after which subduction is lubricated and mostly inhibits rock recovery.

This contribution places bounds on the plate interface constitution, regular thickness ( $<300 \mathrm{~m}$; i.e. where/when there is no detachment), changing geometry and effective viscosity. The concept of 'coupled thickness' is used here to capture subduction interface dynamics, notably during episodes of strong mechanical coupling, and to link long- and short-term deformation. Mechanical coupling depends on mantle wedge rheology, viscosity contrasts and initial structures (e.g.,heterogeneous lithosphere, existence of décollement horizons, extent of hydration, asperities) but also on boundary conditions (convergence rates, kinematics), and therefore differs for warm and cold subduction settings. Although most present-day subduction zone segments (both along strike and downdip) are likely below the detachment threshold, we propose that the most favorable location for detachment corresponds to the spatial transition between coupled and decoupled areas. Effective strain localization involves dissolution-precipitation and dislocation creep but also possibly brittle fractures and earthquakes, even at intermediate depths.

\section{Contents}

1. Introduction . . . . . . . . . . . . . . . . . . . . . . . . . . . . . . . . . . . . . . . . . . . . . . . 2

2. Plate interface geometry across depths . . . . . . . . . . . . . . . . . . . . . . . . . . . . . . . . . . . . . . . . . . 3

2.1. From geophysical data . . . . . . . . . . . . . . . . . . . . . . . . . . . . . . . . . . . . . . . . . 3

2.2. From geological data . . . . . . . . . . . . . . . . . . . . . . . . . . . . . . . . . . . . . . . . . . . . . . . . . . . . . 4

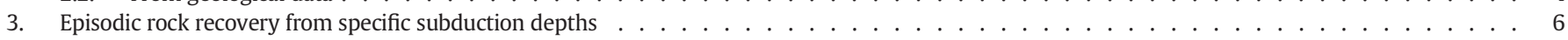

\footnotetext{
* Corresponding author.

E-mail address: philippe.agard@sorbonne-universite.fr (P. Agard).
} 
4. Evidence that transient changes in mechanical coupling control rock recovery . . . . . . . . . . . . . . . . . . . . . . . . . . 7

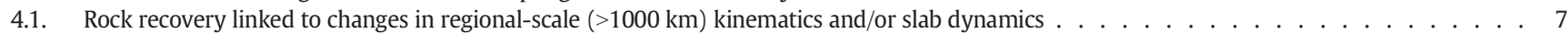

4.2. Sequential underplating at 30-40 km depth. . . . . . . . . . . . . . . . . . . . . . . . . . . . . . . . . . . . . . . . . . . . . . 7

4.3. Detachment and underplating during subduction infancy. . . . . . . . . . . . . . . . . . . . . . . . . . . . . . . . . . . . 8

4.4. Detachment of tectonic slices from the slab in numerical models . . . . . . . . . . . . . . . . . . . . . . . . . . . . . . 9

4.5. Mechanical coupling: from long- to short-term . . . . . . . . . . . . . . . . . . . . . . . . . . . . . . . . . . 10

5. Further evidence from diagnostic fossil exposures . . . . . . . . . . . . . . . . . . . . . . . . . . . . . . . . . . . . . . . . . . 10

5.1. Data selection and rock types . . . . . . . . . . . . . . . . . . . . . . . . . . . . . . . . . . . . . . . . . . . . . . . . 12

5.2. Characteristic trends in pressure, temperature, $\mathrm{T} / \mathrm{P}$ gradient, thickness and relative timing of recovery . . . . . . . . . . . . . . . . . . . 14

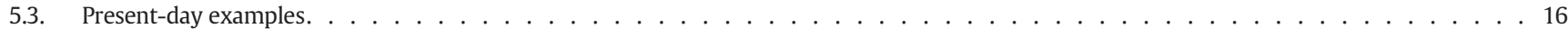

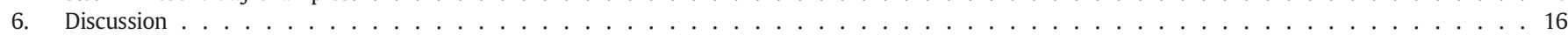

6.1. Conditions of rock recovery: pressure, temperature, $\mathrm{T} / \mathrm{P}$ gradients, thickness and timing . . . . . . . . . . . . . . . . . . . . . . . 16

6.1.1. T/P gradients: no significant overpressures . . . . . . . . . . . . . . . . . . . . . . . . . . . . . . . . . 16

6.1.2. Trustable natural probes for the plate interface . . . . . . . . . . . . . . . . . . . . . . . . . . . . . . . 16

6.1.3. Maximum depths .. . . . . . . . . . . . . . . . . . . . . . . . . . . . . . . . . . 16

6.1.4. Preferential depths for recovery? . . . . . . . . . . . . . . . . . . . . . . . . . . . . . . . . . . . . . . . . 16

6.1.5. Punctuated, but when and what? . . . . . . . . . . . . . . . . . . . . . . . . . . . . . . . . . . 17

6.2. Long-term interplate mechanical coupling . . . . . . . . . . . . . . . . . . . . . . . . . . . . . . . . . . . . . . . . . . 17

6.2.1. Long-term trend with subduction cooling. . . . . . . . . . . . . . . . . . . . . . . . . . . . . . . . . . . . . . 17

6.2.2. Differences for cold or warm settings? . . . . . . . . . . . . . . . . . . . . . . . . . . . . . . . . . . . . . . . . . . 17

6.3. Subduction interface thickness . . . . . . . . . . . . . . . . . . . . . . . . . . . . . . . 19.

6.3.1. Plate interface thickness . . . . . . . . . . . . . . . . . . . . . . . . . . . . . . . . . . . . . . 19

6.3.2. Coupled thickness . . . . . . . . . . . . . . . . . . . . . . . . . . . . . . . . . . 19

6.4. Mechanical coupling and strain (de)localization processes . . . . . . . . . . . . . . . . . . . . . . . . . . . . . . . . . . . . 19

6.5. Bridging long and short time scales. . . . . . . . . . . . . . . . . . . . . . . . . . . . . . . . . . . . . . . . 22

6.5.1. Stability of mechanical coupling through time. . . . . . . . . . . . . . . . . . . . . . . . . . . . . . . 22

6.5.2. Creeping or seismic? . . . . . . . . . . . . . . . . . . . . . . . . . . . . . . . . . . . . . . . 22

7. Conclusions. ...................................................22

. . . . . . . . . . . . . . . . . . . . . . . . . . . . . . . . . . . . . . . . . . . . . . 23

References. . . . . . . . . . . . . . . . . . . . . . . . ..................23

\section{Introduction}

Mechanical coupling and material transfer at and across subduction plate boundaries (hereafter the 'plate interface') interact on a wide range of spatial and temporal scales $\left(10^{-6}\right.$ to $10^{6} \mathrm{~m}, 10^{0}$ to $\left.10^{15} \mathrm{~s}\right)$, with dramatic consequences for earth dynamics and risk assessment. Although intrinsically weak to accommodate mantle convection during millions of years, strong mechanical 'coupling' regularly builds up across the plates, causing (i)recurring mega-earthquakes at the human time scale (in Sumatra, Chile, Japan) and (ii) episodic return, at the million year scale, of slab fragments metamorphosed along subduction at high-pressurelow-temperature (HP-LT) conditions.

The nature, structure and properties of the subduction plate interface (i.e.,lithology, geometry, thickness, rheology, and how these change with depth) are still largely unknown, however, due to the lack of direct access and poor imaging beyond a few km depth (e.g. Nantroseize, Japan). And these two short- and long-term 'coupling' processes, though taking place along/across the very same plate interface (Fig. 1), are at present studied mostly independently and through very different approaches.

High-end monitoring of active subduction zones and related geophysical studies (i.e.,using seismological, GPS, InSAR or magnetotelluric methods) have, over the past two decades, improved our knowledge on short-term mechanical coupling and stress release (Peng and Gomberg, 2010 and references therein; Gao and Wang, 2017) and revealed new types of seismic phenomena, notably slow-slip events (Ide et al., 2007; Schwartz and Rokosky, 2007). Using ad hoc rheological properties of the plate interface (i.e.,rate-and-state behavior or brittle-viscous transitions: Scholz, 1998; Gao and Wang, 2014; Fagereng and den Hartog, 2017), many studies focus on mechanical coupling at the scale of (a fraction of) the seismic cycle (Métois et al., 2016; Gao and Wang, 2017; van Dinther et al., 2013; Sobolev and Muldashev, 2017; Corbi et al., 2013; Zheng et al., 2016). At the other end of the spectrum, transient changes in (long-term) mechanical coupling have been invoked for fossil subduction zones to account for the punctuated recovery of subducted rocks (Maruyama et al., 1996; Agard et al., 2009, 2016; Monié and Agard, 2009; Plunder et al., 2015; Ruh et al., 2015).

What is in common, therefore, between stress accumulation and strain localization during the seismic cycle and stress-strain relationships during the detachment and/or exhumation of rock fragments? For example, rock recovery requires, prior to exhumation, a shift of the plate contact into the slab to detach fragments: could this deformation be operating on the scale of seismic cycles? The mechanical impact of seamounts (whose role as seismic barrier or asperity is much debated: e.g., Cloos, 1992; Mochizuki et al., 2008; Wang and Bilek, 2011; Geersen et al., 2015; Ruh et al., 2016) is expected to last a few hundred thousand years at least: how permanent is 'coupling' through time?

That short- and long-term processes might be more readily connected has emerged from studies linking mineral transformations, fluid release and seismicity at or close to the plate interface (i.e.,Audet et al., 2009; Audet and Kim, 2016; Hacker et al., 2003; Rogers and Dragert, 2003). There is indeed a growing body of evidence from the (fossil) rock record that at least some of the episodes of their long geological evolution match or are close to timescales of the seismic cycle. Recent findings address very different aspects, such as underplating (Kimura et al., 2010), fluid-rock interactions (John et al., 2012; Penniston-Dorland et al., 2010; Taetz et al., 2018), fluid pressure changes (Vannucchi et al., 2008), element transfer (Audet and Bürgmann, 2014; Fisher and Brantley, 2014) and switches in brittle/ ductile deformation (Fagereng, 2011a, Angiboust et al., 2012a; Sibson, 2013; Yamaguchi et al., 2012; Menant et al., 2018).

Using HP-LT rocks recovered from subduction zones as natural probes is presently the only way to gain high-resolution, $\mathrm{m}$ - to hmscale insights on the constitution of the plate interface (Stöckhert, 2002), and on the complex interplay between physical and chemical transformations, deformation and fluids (Agard et al., 2016; Bebout and Penniston-Dorland, 2016; Fagereng and den Hartog, 2017; Wassmann and Stoeckhert, 2013 and references therein). 
a

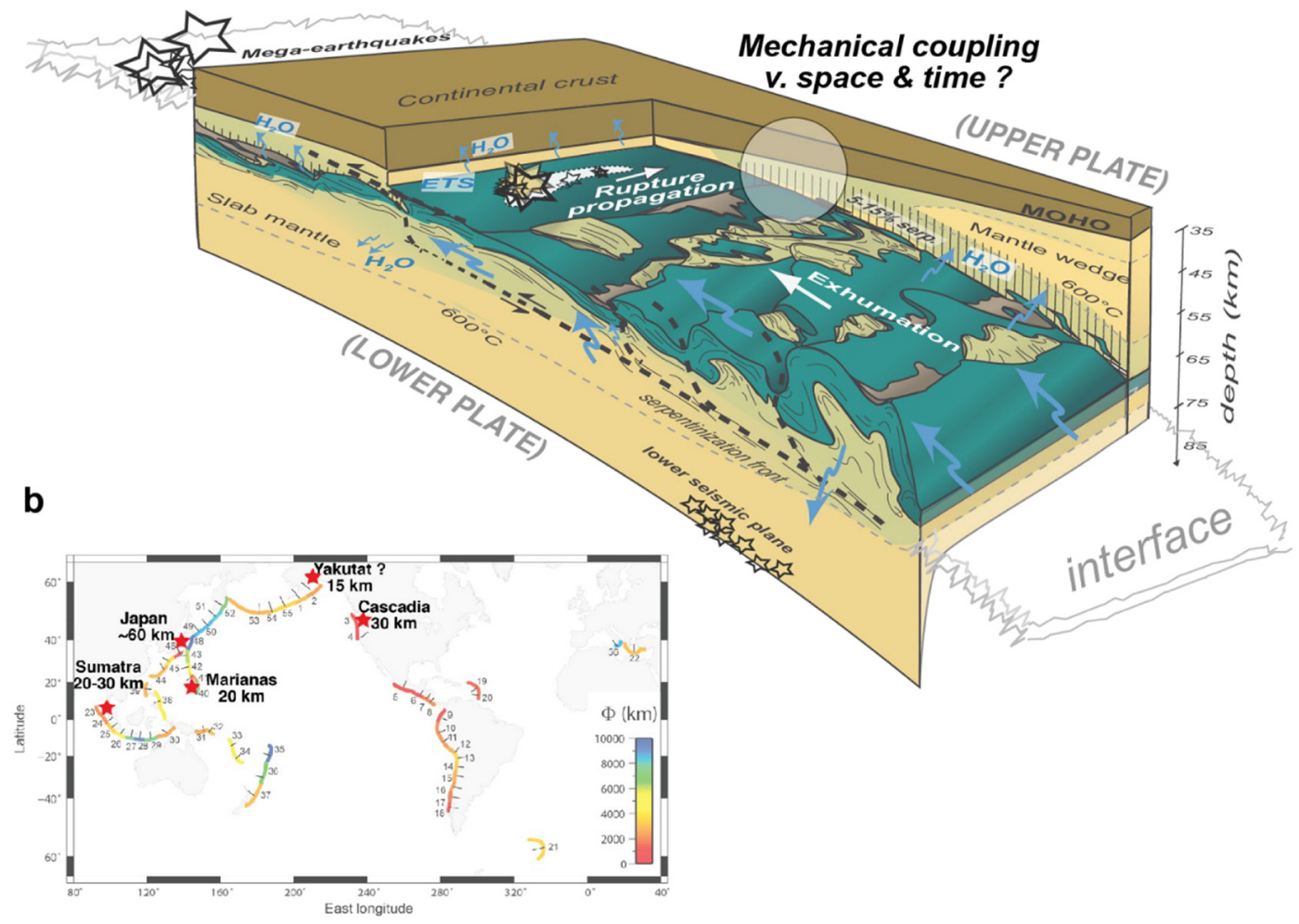

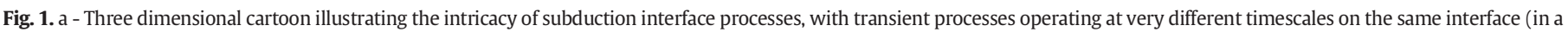

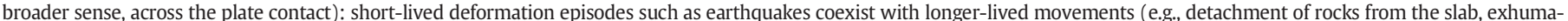

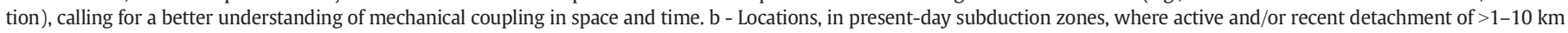

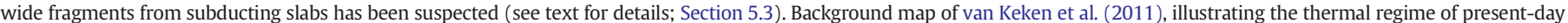

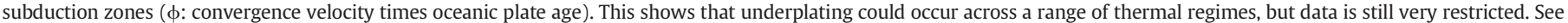
Section 5.3 for references.

Understanding what these rocks exactly record is therefore of prime importance and, as for absolute earthquake relocation, setting back HP-LT rocks with respect to the plate interface is essential.

The present contribution intends to critically assess the provenance of these rocks, the conditions of rock recovery along the plate interface, the information they preserve and how they help us track mechanical coupling (or any other process) along the plate interface. First, we redefine and review the current knowledge on the constitution of the plate interface (Section 2), the depths from which these rocks are recovered (Section 3) and provide supporting evidence, based on examples studied by our group or others (e.g.,Monié and Agard, 2009; Plunder et al., 2015; Wakabayashi et al., 2015), that long-term mechanical coupling exerts a key control on their recovery (Section 4). We then further scrutinize the fossil record (Section 5), based on a comprehensive compilation of pressure ( $\mathrm{P}$; converted to depth) and temperature (T)conditions, $\mathrm{T} / \mathrm{P}$ gradients, timing of detachment and thickness of rock units, for carefully selected localities preserving oceanic fragments sliced off from the top of the slab (i.e., $<\sim 500 \mathrm{~m}$ away from the plate interface) during long-lasting oceanic lithosphere subduction. Results and new concepts are discussed with emphasis on (i)the evolution through space and time of long-term tectonic slicing, (ii) parameters controlling changes in mechanical coupling and (iii) short- to long-term physical mechanisms leading to effective detachment from the slab and rock recovery (Section 6).

\section{Plate interface geometry across depths}

Not much is known about the constitution of the plate interface at depths greater than a few kilometers (Oncken et al., 2003; Sage et al., 2006: Calahorrano et al., 2008; Contreras-Reyes et al., 2017), and available images provide a km-scale view at best. The NantroSeize project (e.g., Lewis et al., 2013) has not drilled through the plate boundary yet and will only at most access its shallow part. Absolute earthquake relocation is fraught with uncertainties on the order of 1 to $5 \mathrm{~km}$ (e.g., Rietbrock and Waldhauser, 2004), equivalent to those associated with depth assessment of HP-LT rocks ( 0.05-0.2 GPa, i.e. $~ 0.2$ to $7 \mathrm{~km}$; Plunder et al., 2012). Similarly, assessing the past location and distance of a given blueschist or eclogite facies sample from the plate interface is difficult and rarely done.

Published views on the plate interface geometry (starting from England and Holland, 1979; Shreve and Cloos, 1986; Cloos, 1992) largely depend on whether they are based on field observations or geophysical data (as noted by Vannucchi et al., 2012; see Section 2.2). For the sake of clarity, the glossary of Table 1 and Fig. 2 provide the terminology used throughout the text (notably coupling, detachment, accretion/underplating and exhumation).

The term 'plate interface' is used throughout this contribution to describe the domain between the lower and upper plates, including their boundaries (Fig. 2a,b). We regard this term as less interpretative than 'subduction channel' which, in the literature of the last 30 years, often implicitly conveyed the idea of continuous return flow (e.g.,Gerya et al., 2002). Besides, the geometry is so poorly-constrained that there might be areas along the plate interface where there is no channel at all (and/or no 'control point' as defined by Shreve and Cloos, 1986).

\subsection{From geophysical data}

Fig. $2 c$ attempts to encapsulate current views on the plate interface as seen from geophysical data. Structures across depths are increasingly well imaged by seismology (e.g.,Abers, 2005; Abers et al., 2006; Bostock 
Table 1

Glossary of the major concepts/terms used in the present manuscript.

'Plate Interface' - It is characterized by two tectonic contacts (here named after Vannucchi et al., 2012): the 'roof décollement' (upper boundary) and 'basal décollement' (lower boundary), each of unknown width. These are the hanging wall and footwall of Shreve and Cloos (1986).

'Plate Interface 'Thickness' - It refers to the total width of the plate interface, i.e. comprising the roof and basal décollements and the domain in between (this last one being generally referred to as the 'Channel'). Its value is not known with any precision and could vary from the $\mathrm{cm}-\mathrm{m}$ scale at shallow depths (Saffer and Tobin, 2011; Vannucchi et al., 2012b) to the km-scale deeper down (as suggested during subduction infancy; Agard et al., 2016).

'Channel Material' - This term is restricted to rocks located between the roof and basal décollement (Fig. 2a), whose displacement, during at least part of its evolution, does not coincide with those of the upper and lower plates. This material may be intact (meta)sedimentary sequences or oceanic crust or may be partly disrupted, incorporating various amounts of tectonic slices of variable dimensions, possibly leading to the formation of mélanges (see next point). There might be also virtually no material (in case of zero plate interface thickness).

'Mélange' - This is a formation made of mixed rock bodies that are mappable (at $1: 25,000$ or less) and in which the proportion of blocks to matrix turns out to be $<\sim 50-70$ vol\% in subduction zone environments (Grigull et al., 2012). Unless specified, we implicitly refer to a tectonic mélange (i.e., dismantling of preexisting structures by deformation along the plate interface, regardless of potential inherited heterogeneities) rather than sedimentary mélange (which may turn into a tectonic mélange in the interface; e.g., Cowan, 1978; Cloos, 1982; Festa et al., 2012). The extent to which tectonic mélanges form by mechanical mixing and chemical mixing (i.e. by progressive reactions between the various rock types and/or fluids leading to chemical and rheological changes, with complex feedbacks) is generally unknown.

'Detachment' - This designates effective slicing of rocks/units from the slab (irrespective of effective deformation mechanisms or tectonic offsets), which inherently requires a down-stepping of the basal décollement and leads to the net addition of material to the interface. Any detachment requires strain localization into the slab and significant mechanical coupling (see below) across the plate boundary so that some strain is effectively transferred into the slab rather than focused across the plate interface alone (Fig. 2b).

'Underplating' - This process corresponds to the net addition (or accretion, in a broad sense) of material to the upper plate, hence involving a down-stepping of the roof décollement and transfer of channel or slab material to the upper plate. This may comprise underplating of incoming (fresh) material or of previously detached material (whether experiencing exhumation or not; Fig. 2b). The term 'Frontal Accretion' is restricted here to shallow accretion of material, i.e. within the non-subducted accretionary wedge. Subducted material, by definition, corresponds to rocks dragged pass the inlet of the plate interface (Fig. 2a).

'Exhumation' - This term describes the upward movement of material within the plate interface (by opposition to burial), whether in the channel or along one of the boundaries (more likely roof than basal décollement; Raimbourg et al., 2007). Exhumation, probably in part 'buoyancy-propelled' (Ernst, 2001), is still not well understood (see Platt, 1993; Warren, 2013 and references therein).

'Basal erosion' - This term refers to the removal of material from the upper plate (whether previously underplated or not).

'Mechanical coupling' - This is defined, at any given depth, as the integrated resistance across the interface (and along some characteristic distance in 3D).

Plates in contact are locally 'increasingly coupled' when not sliding at average plate velocities with respect to each other for some distance and time ('Partial Locking' on Fig. 2b), i.e. when the sum of relative displacements across the plate interface (at the roof and/or basal décollement and/or within channel material) is less than required by convergence. Strain distribution is modified whenever plates get 'increasingly (or strongly) coupled', as well as during opposite evolutions. Strain accumulation may induce localization within the downgoing plate (detachment) or the upper plate (basal erosion). We define the 'Coupled Thickness' (Fig. 2b) as the width across which strain is effectively distributed, such that coupled thickness $\geq$ plate interface thickness (see Section 6.3). For the sake of simplicity, when the coupled thickness equals the plate interface thickness (i.e., the integrated strength equals that of the channel material and décollements), plates are termed 'decoupled' (somewhat abusively since this does not mean there is no mechanical coupling). This definition of mechanical coupling is similar to the one used in the geophysical literature to describe variations in seismic coupling depth (Tichelaar and Ruff, 1993; Oleskevich et al., 1999) or interseismic/geodetic coupling (e.g., Wallace et al., 2012; Métois et al., 2016). At intermediate timescales, mechanical coupling can be envisioned as the integrated resistance across the whole plate contact (e.g., Agard et al., 2016; Riel et al. 2017). Implicit in all these definitions, increased mechanical coupling means higher stresses along a partly 'locked' portion but not necessarily across the whole plate interface. et al., 2002; Paulatto et al., 2017; Saffer and Wallace, 2015), at least in areas illuminated by earthquakes/signals (i.e.,trench geometries commonly restrict instrumentation and coverage of the $10-30 \mathrm{~km}$ depth range, or 'white zone'). It is nevertheless beyond the scope of this contribution to review the huge progress made over the past twenty years on subduction-zone seismicity, moving from Wadati-Benioff to double (or triple) seismic planes, from regular earthquakes (EQ) to slower ones (Ide et al., 2007; Schwartz and Rokosky, 2007), or on source mechanisms or stress drop estimates (e.g.,Gao and Wang, 2017).

The seismogenic zone (or locked zone; 15 to $25-30 \mathrm{~km}$; Fig.2c) is bounded by conditionally stable (i.e.,potentially velocity weakening) areas into which ruptures may propagate and finally die out (Lay et al., 2012). Its downdip end ( $\left.35-40 \mathrm{~km}, 1-1.2 \mathrm{GPa}, \sim 350{ }^{\circ} \mathrm{C}\right)$ is thought to represent the transition between the brittle field and the domain dominated by plastic deformation. In warm subduction zones, this area is also the locus of episodic tremor and slip characterized by slow energy dissipation at the scale of several weeks (ETS; Rogers and Dragert, 2003), thought to be associated with fluid release beneath an impermeable seal (Audet et al., 2009; Nakajima and Uchida, 2018; Fig.2c). Fluid and mass transfer between the ETS region and shallower up-dip portions along the plate interface has recently been suggested (Fig.2c; Fisher and Brantley, 2014; Audet and Burgmann, 2014).

Deeper down, beyond the seismogenic zone, earthquakes are interpreted as within plate because low stresses (Oleskevich et al., 1999) and ductile behavior are thought to prevail on the plate interface (at least when 'decoupled'). The presence of fluids and serpentine minerals, suggesting fluid liberation into the wedge corner, has been argued based on estimates of Vp, Vs and Vp/Vs ratios. The hydration state of the mantle wedge is nevertheless largely debated (Abers et al., 2017; Hyndman and Peacock, 2003). At some distance above and away from the interface $(>20-30 \mathrm{~km})$, mapping of the attenuation factor $(\mathrm{Q}) \mathrm{re}$ veals the presence of fluids and/or melts (Fig.2c).

The plate interface itself was estimated to be no more than a few kilometers thick (Abers, 2005; Hilairet and Reynard, 2008) but only blurry pictures exist for now. On the other hand, receiver-function techniques have imaged on most subduction zones a low-velocity horizon (LVH) located at the top of the slab and associated with a variety of the recently discovered seismic manifestations (silent-slip, low or very-low frequency earthquakes; SSEs; LFEs; VLFEs; Bostock, 2013). The LVH is believed to coincide with the oceanic (mafic) crust, probably its upper portion (i.e., basalts of Layer 2; Hansen et al., 2012). Others have suggested that it may also in part be located in a sedimentary horizon (Abers et al., 2009). The downdip end of the LVH, from $\sim 50 \mathrm{~km}$ (Cascadia) to $120 \mathrm{~km}$ (NE Japan), correlates well with thermal structure (deeper ones for colder ones) and seems to dip into the slab and die out once the blueschist to eclogite transformation is completed (Fig.2c; Kita et al., 2006; Rondenay et al., 2008; van Keken et al., 2012). A lower seismic plane, $20-40 \mathrm{~km}$ into the slab mantle, whose origin is still debated (i.e., related to serpentine breakdown or bending), is also imaged for most subduction zones (e.g.,Zhao et al., 2009; Fig.1a).

\subsection{From geological data}

Plate interface thickness, not (yet) constrained by geophysical methods, was estimated for shallow depths $(<15 \mathrm{~km}$; Rowe et al., 2013) by inspection of fault drills from subduction environments and exhumed portions. These authors concluded on the existence of a 100-350 m thick, depth independent multi-strand fault system (outside potentially accreted/underplated material). Though not preventing the possibility of material return, no supporting evidence was found. Such thickness makes steady return flow unlikely, even with deformable plate walls (Raimbourg et al., 2007).

There is no direct information at greater depth, justifying the need for the present compilation (Section 5). The variety of subducted materials is immense, from slow to fast spreading lithosphere or oceanic plateaus with thick crust. Plate interface thickness is likely to be modulated 


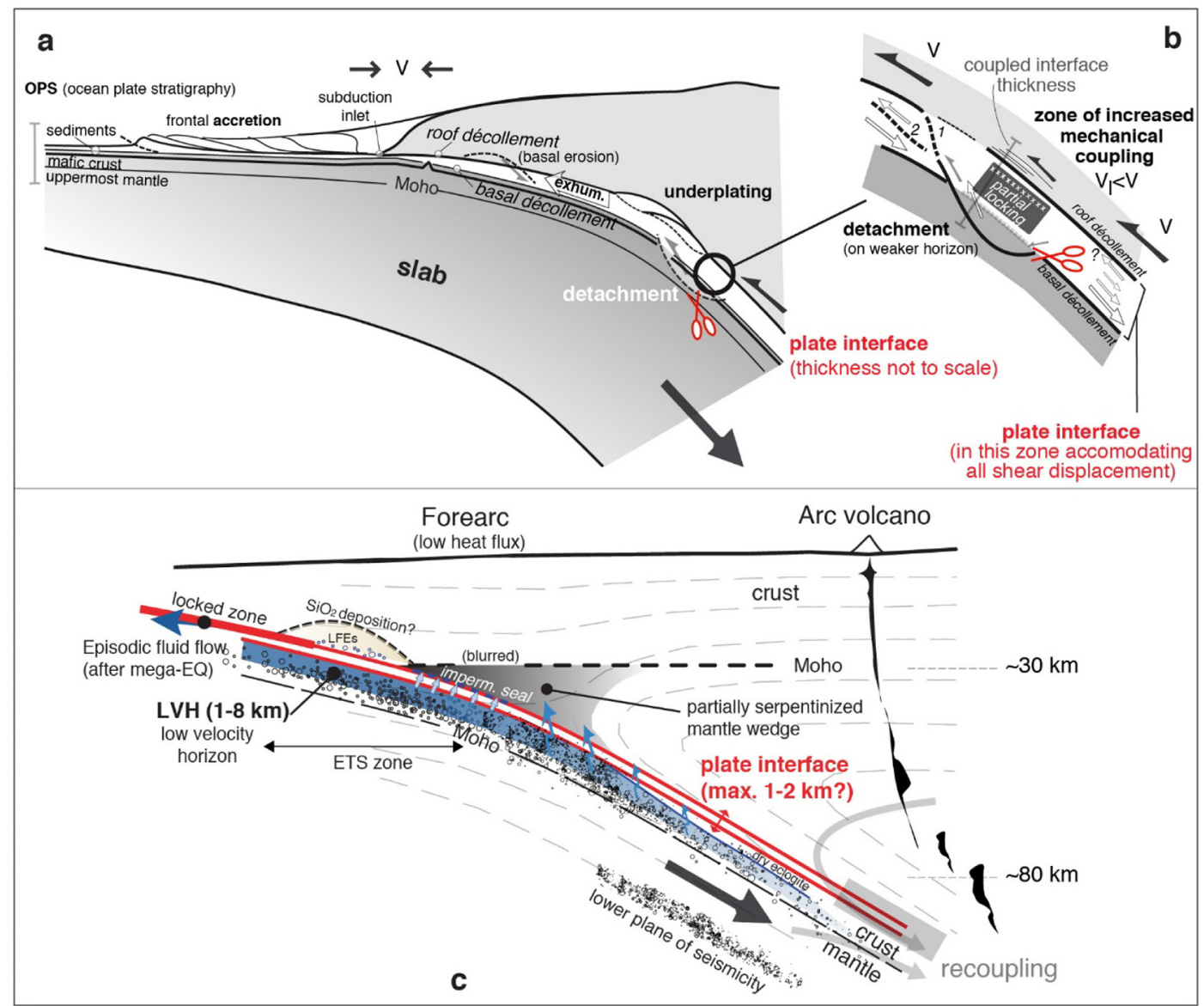

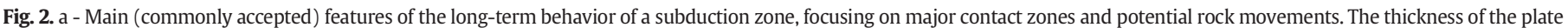

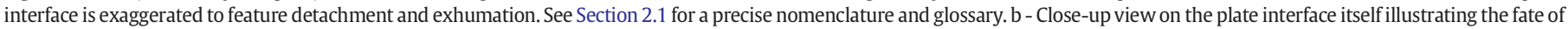

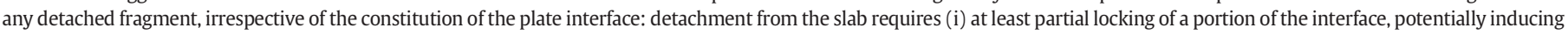

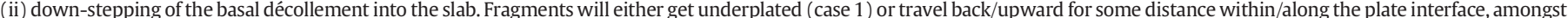

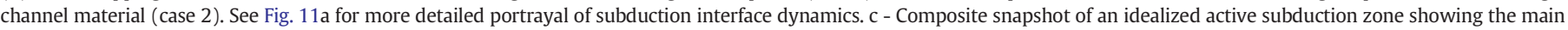

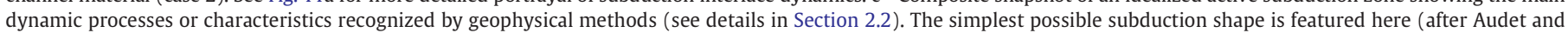

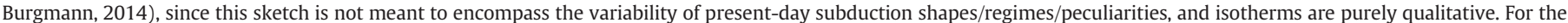

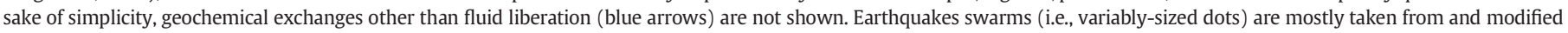
after Bostock (2012) and van Keken et al. (2012). (For interpretation of the references to color in this figure legend, the reader is referred to the web version of this article.)

by the type of material/lithology involved and mixing proportions (e.g., Fagereng and den Hartog, 2017). Fluid budgets seem critical and particularly influenced by the hydrothermal alteration of basalts (Spinelli, 2014) and serpentinization at the top of the lithospheric slab (in the first 1-5 km: Fig. 2a; Emry and Wiens, 2015). Variations in ocean plate stratigraphy (OPS, Fig. 2a), particularly for sediments, have been discussed in a number of publications (Wakabayashi et al., 2011, 2015; Kusky et al., 2013; Wakita, 2012), but their impact on subduction mechanics is relatively poorly known (Agard et al., 2016; Behr and Becker, 2018). Frontal accretion, though not considered here (this material does not enter into subduction much, unless aerial or basal erosion proceeds), likely impacts plate interface thickness: since accretion is favored by slower plate convergence (yet mostly independent from incoming sediment thickness, generally between 0.5 and $1 \mathrm{~km}$; Cliff et al., 2004; Syracuse et al., 2010), fast convergence will result in more sedimentary material dragged along the plate interface.

Field-based, idealized views of the plate interface provide more details but generally lack scale and/or information on the distance to the plate interface (e.g.,Angiboust et al., 2015; Bachmann et al., 2009; Konrad-Schmolke et al., 2011; Fagereng, 2011a,b; Kimura et al., 2012; Vannuchi et al., 2012; Rowe et al., 2013; Wakabayashi, 2015; Guillot et al., 2009, 2015). It is beyond the scope of this study to describe or reappraise the merits of all published representations, but most focus on two distinct depth ranges:
- shallow depths < 20-25 km, in Japan (Kitamura et al., 2005; Kimura et al., 2012; Raimbourg et al., 2014), New Zealand(Fagereng et al., 2011), California (Wakabayashi, 2015, 2017) or the Western Alps (Bachmann et al., 2009).

- depths >35-40 km (Ague, 2017; Angiboust et al., 2012b,c, 2015; Bebout, 2007; Guillot et al., 2015; Konrad-Schmolke et al., 2011). For these, constraints from fluid-rock interactions, related mineral textures and detailed geochemistry are increasingly available (Bebout, 2007; Bebout and Penniston-Dorland, 2016), but the exact tectonic setting is less well constrained (save for a few examples; e.g. Monviso massif, W. Alps: Angiboust et al., 2011 and references therein).

Field-based pictures highlight ductile deformation, shear bands or boudinage but differ in terms of strain localization (strongly localized or distributed shear), material behavior/status (coherent slices or variably disrupted mélanges) and fluid regime. Fossil deformation commonly reveals (i)a combination of deformation mechanisms, such as grain-size sensitive creep (mostly dissolution-precipitation creep; Stöckhert, 2002; Wassmann and Stoeckhert, 2013) and dislocation creep and (ii) fluctuations between brittle and ductile behavior owing, notably, to changes in fluid pressure (e.g.,at the hm-scale: Angiboust 
et al., 2015; for large-scale, present-day changes: Wallace et al., 2012). Although essential physical parameters such as permeability or porosity remain largely unknown, many efforts have been devoted over the last 10 years to link long-term deformation to earthquakes (Marone and Richardson, 2010; Andersen and Austrheim, 2006; Fagereng et al., 2011, 2018; Angiboust et al., 2012a).

\section{Episodic rock recovery from specific subduction depths}

The punctuated exhumation record (Agard et al., 2009; Angiboust et al., 2016; Guillot et al., 2009) shows that rock recovery is intrinsically episodic: subducted rocks are returned over relatively short-lived episodes representing only a fraction of subduction lifetime $(<20 \%$, typically during a few Myr; Fig. 3a), and each time across only a small part of the subduction zone length (e.g., $<5 \%$ for the Neotethys or S. America). Altogether, rock recovery amounts to a few percents at most. This rules out a steady return flow process (a concept mainly derived from numerical models: Cloos and Shreve, 1988a,b; Gerya et al., 2002), at least across a significant part of the subduction history (see also the discussion in Krohe, 2017; Wakabayashi, 2017).

Maximum depths at which exhumed rocks did equilibrate, i.e., reached their peak burial, is likely not random: despite some scatter, two main depth clusters were pointed out by Plunder et al. (2015); Fig. 3b): at $\sim 30-40 \mathrm{~km}$ (i.e., downdip of the seismogenic zone) and at $\sim 80 \pm 10 \mathrm{~km}$, perhaps with one additional peak at $\sim 50-55 \mathrm{~km}$. The rock record may be biased for shallow depths, i.e. leaving aside rocks not recognized as having once been subducted due to difficulties in assessing P-T values for low temperatures $\left(<\sim 250{ }^{\circ} \mathrm{C}\right.$, or $20-25 \mathrm{~km}$ forsubduction zone gradients), but diagnostic minerals and thermodynamic models for both metasedimentary and metabasic rocks confidently cover the range for $P>.4 \mathrm{GPa}$ and $T>250^{\circ} \mathrm{C}$.
The lesser recovery (or gap) between depths of 30-40 and $80 \mathrm{~km}$ spatially coincides with the depth range over which the oceanic slab is juxtaposed against the mantle wedge, beyond the continental Moho (Fig. 3b), i.e. at modelled upper plate temperatures low enough that some rheologically weak serpentine material should be stable $(<550$ $600{ }^{\circ} \mathrm{C}$; Figs.2c and 3b; Ulmer and Trommsdorff, 1995a,b; Hyndman and Peacock, 2003; Reynard, 2013; Hilairet and Reynard, 2009; Guillot et al., 2015). This lesser recovery, once rocks are in contact with the partly serpentinized mantle wedge, is intuitively consistent with lubrication of the plate interface by serpentinites. We note, however, that serpentine stability depends on subduction thermal structure and may extend down to 100-120 km in cold subduction zones (van Keken et al., 2011) and that no or a very limited number of rocks are recovered beyond $\sim 80 \mathrm{~km}$ (Agard et al., 2009; Plunder et al., 2015; Fig. 3b).

The depth range of most exhumed rocks therefore spatially coincides with marked changes in first-order features and mechanical coupling in active subduction zones, as shown in Fig. 3c (e.g.,hydration or dehydration sites, mega-earthquakes, ETS,intermediate-depth earthquakes): (i)from the seismogenic zone to a portion below generally considered as decoupled (30-40 km; Peacock and Hyndman, 1999; Lay et al., 2012; Audet and Bürgmann, 2014; Gao and Wang, 2017) and (ii) from decoupled to recoupled depths ( $\sim 80 \mathrm{~km}$; Wada and Wang, 2009; Syracuse et al., 2010). This observation raises several important remarks:

- does the rock record reliably reflect depths at which rocks get scraped off (hence detachment dynamics) or instead some process preventing the recovery of already detached slices? The latter could be (i)an exhumation barrier, whether geometrical and/or rheological (Brun and Faccenna, 2008), (ii) an efficient dragging along the interface beyond a 'critical point' (Shreve and Cloos, 1986) or

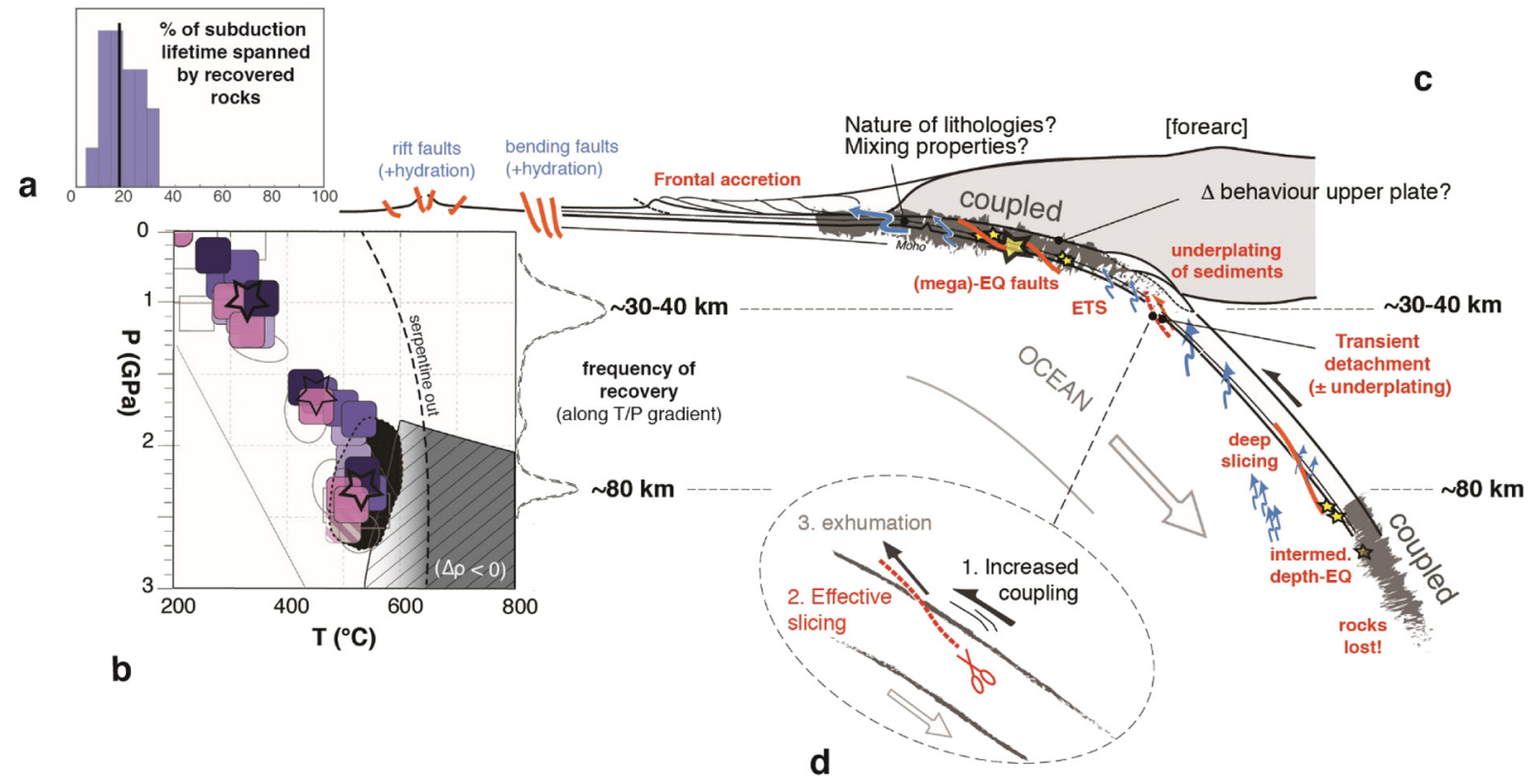

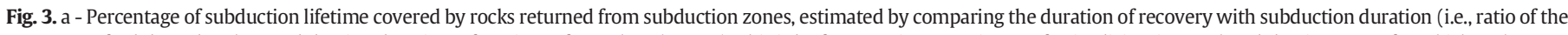

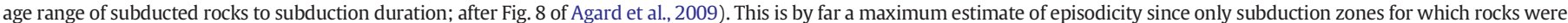

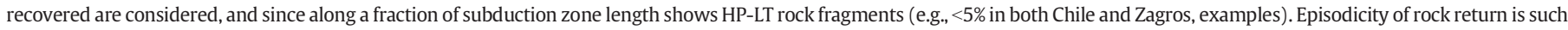

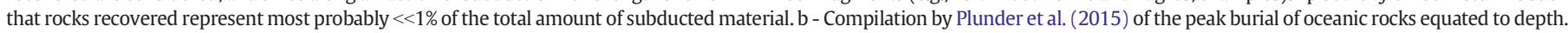

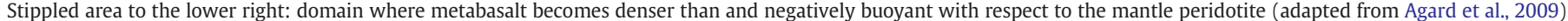

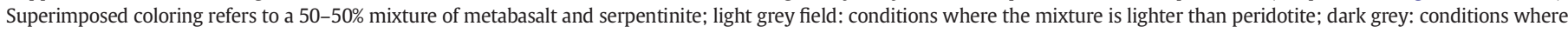

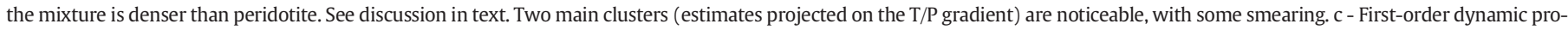

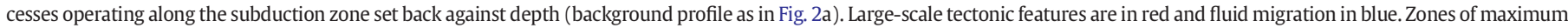

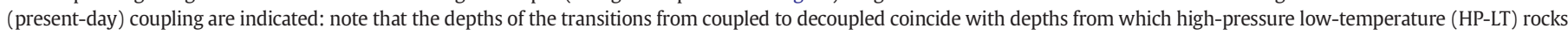

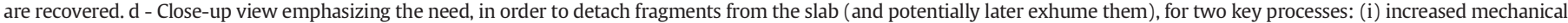

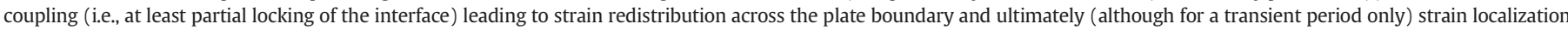

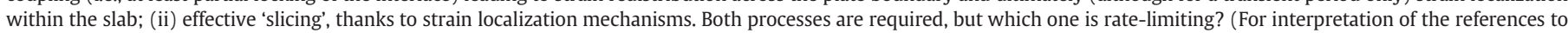
color in this figure legend, the reader is referred to the web version of this article.) 
result from (iii) substraction across a given depth range, for example by relamination or diapirism, of sediment and/or hybridized material (Gerya et al., 2008; Hacker et al., 2011; Marschall and Schumacher, 2012; Hacker and Gerya, 2013; Nielsen and Marschall, 2017). Section 4 provides evidence supporting detachment-controlled recovery.

- could episodicity be an artifact due to switches between subduction accretion and erosion, the latter inducing full subduction of the OPS and removal of upper plate or underplated material (Clift and Vannucchi, 2004; Sallares and Ranero, 2005; von Huene and Scholl, 1991)? Subduction erosion, by essence elusive unless some material is later returned (for the few reports of basal erosion: Grove et al., 2008; Angiboust et al., 2018; one recent claim of mid- to lowercrustal material: Zhang et al., 2017), would nevertheless not explain why recovery is depth-dependent and/or why in most cases exhumation pulses seem to be rather short-lived (see below).

- are pressure estimates reflecting correct depths, i.e. what is the extent of over-pressure (e.g.,Schmalholz and Podladchikov, 2014)? Its importance in subduction environments is probably minimal, given the consistency between petrological and geophysical observations and the lateral homogeneity/extent of regional-scale exposures, but this point is further discussed in the light of the present compilation (Section 6.1).

Episodicity of the rock recovery (irrespective of depth) suggests the existence of a rate-limiting process. Since down-stepping of the subduction interface into the slab is necessary to scrape off rocks/units, it could be (i)the extent of mechanical coupling between the two plates or (ii) strain localization and slicing mechanisms in the slab (Fig. 3d: 1 and 2, respectively). As slabs undergo extensive deformation prior to reaching depths of 30-40 km (i.e., faults form at or near the ocean ridge, during bending and along the seismogenic zone; Fig. 3c; Ranero et al., 2003; Rietbrock and Waldhauser, 2004), the second hypothesis seems less likely, unless efficient healing mechanisms erase weakness/fault zones beyond $30-40 \mathrm{~km}$. These aspects are examined in the next section and in the Discussion.

\section{Evidence that transient changes in mechanical coupling control rock recovery}

4.1. Rock recovery linked to changes in regional-scale (>1000 km) kinematics and/or slab dynamics

We consider below two well-documented examples from the Mesozoic, from the Tethyan and Pacific realms respectively.

(1) Within the Neotethys, across $>3000 \mathrm{~km}$ (from approx. Turkey to the Himalayas; Fig. 4a; Monié and Agard, 2009), most ocean-derived blueschists were returned coevally from a long-lived subduction system ( $>100 \mathrm{Myr}$ ), over a short time interval $<\sim 20 \mathrm{Myr}(\sim 90 \pm 10 \mathrm{Ma})$ from depths around 30-40 km (Fig. $4 \mathrm{~b})$. These blueschists crop out as tectonic slices with fairly intact OPS sequences.

The similarity of ages supports fresh slicing from the slab rather than recovery from a 'storage' zone: exhumation of previously, diachronously detached pieces would have led to different ages (especially for relatively low-T rocks that did not significantly exceed closure temperature of radiometric systems). It also indicates that detachment was rate-limiting: recovery across such a vast area requires that detachment was triggered by regionalscale (mantle-scale) geodynamic changes (Fig. 4a), as a result of plate reorganization and increase in convergence velocities in the Neotethys (Agard et al., 2006, 2007; Jolivet et al., 2016). Their return from similar depths, close to the downdip end of the seismogenic zone (30-40 km; Figs.2c and 4b), suggests changes in long-term mechanical coupling between the upper and lower plates, possibly extending the seismogenic zone downward.

A slightly younger episode of deeper recovery from depths of 50$55 \mathrm{~km}$ (at 70-80 Ma; Seghin unit: Agard et al., 2006; Angiboust et al., 2016; Sapi-Shergol: Groppo et al., 2016) is recorded from the same subduction system. Interestingly, in the nearby Sistan subduction zone, a pulse of rock recovery along $\sim 150 \mathrm{~km}$ is documented at 85 Ma (Eastern Iran; Broecker et al., 2013; Angiboust et al., 2013; Bonnet et al., 2018): two types of mafic rocks returned from depths of 30-40 and $\sim 80 \mathrm{~km}$ are found as m- to $10 \mathrm{~m}$-scale blocks in a serpentinite mélange.

(2) In the Franciscan complex of California, despite $>10,000 \mathrm{~km}$ of eastward subduction, rock recovery was limited. It is characterized by small volumes returned shortly after subduction inception ( 175-170 Ma; Anczkiewicz et al., 2004; Mulcahy et al., 2018; Fig. 4d), of high temperature eclogites (high-grade blocks; Cloos, 1985; Ukar and Cloos, 2014; Wakabayashi, 2015) or slightly more coherent terranes (e.g.,Ward Creek, Goat Mountain, Willow Spring, Skaggs Springs; Wakabayashi, 2015). More volumetrically significant rock recovery and underplating mostly took place during the Cretaceous (Fig. 4c,d). This coincided with large-scale geodynamic reorganization, notably with the reorientation of the Pacific plate at $125 \mathrm{Ma}$, the increase in magmatic production in the Sierra Nevada batholith, the switch from erosional to accretionary mode (Dumitru et al., 2010 and references therein) and predated the period of flat slab subduction (85$45 \mathrm{Ma}$ ). Underplating was discontinuous in space and time (Cloos, 1985; Dumitru et al., 2010; Wakabayashi, 2015). Stepwise underplating of $\sim \mathrm{km}$-thick tectonic slices (Fig. 4c) occurred in the north at $\sim 123 \mathrm{Ma}$ (South Fork mountain schist), $117 \mathrm{Ma}$ (Valentine Springs) and 110-100 Ma (Yolla Bolly terranes) and at 105-80 Ma $300 \mathrm{~km}$ further south, in the Diablo range (Ernst, 1984). All units were returned from similar depths of $\sim 25 \mathrm{~km}$ ( 0.7 GPa; Fig. 4c) as largely non-disrupted slices. Biostratigraphic constraints for the subducted material demonstrate diachronous subduction and thus sequential underplating, suggesting fresh tectonic slicing from the slab rather than recovery from a 'storage' zone.

A similar example of stepwise underplating is provided by the stacking sequence observed in Southern Chile (Almagro island; Angiboust et al., 2018). Another striking example of large-scale, transient recovery is documented in the Guatemala-Cuba-Hispaniola trench at $120 \pm 10 \mathrm{Ma}$ (Garcia-Casco et al., 2008a, 2008b).

\subsection{Sequential underplating at 30-40 km depth}

Peak burial conditions indicate that the $30-40 \mathrm{~km}$ depth range is a favorable locus for detachment of slab material (Fig. 3b). Combined structural and petrochronological data have enabled the identification of stepwise underplating towards the base or below the seismogenic zone ('underplating' in Fig. 3c; e.g.,Platt, 1986; Grove et al., 2008; Plunder et al., 2012; Angiboust et al., 2018). By comparison, much less structural information is available for greater depths.

Underplating requires that the main displacement zone within the plate interface shifts from the roof décollement to within the interface, along the basal décollement or within the slab (Fig. 2b). Recent studies outline a threefold sequence for underplating: (i)scraping off (and strain localization into) the top of the downgoing slab to individualize a tectonic slice, (ii) welding of the slice to the upper plate, in several cases to an earlier underplated sliver and (iii) pervasive shearing of the base of the tectonic slice as it transiently occupies a roof décollement position (e.g.,Angiboust et al., 2018). All these features suggest 
(transient) periods of effective mechanical coupling between the tectonic plates.

This process most commonly involves the uppermost sedimentary section at the slab surface as shown along the Chilean margin or in the Schistes Lustrés complex of the Western Alps (e.g.,Plunder et al., 2012; Willner, 2005), but rocks deeper in the slab sequence may also be involved in duplex structures (Kimura and Ludden, 1995; Kukowski et al., 2002; Hyppolito et al., 2014; seecompilation in Section 5). Ongoing nappe-stacking over tens of millions of years is marked in the rock record by gradually younger deformation ages towards the bottom of the accreted sequence (Franciscan: Dumitru et al., 2010; Chilean Patagonia: Angiboust et al., 2018; Cuba: Despaigne-Diaz et al., 2016, Despaigne-Díaz et al., 2017).

In long-lived margins, this process may lead to the formation of a large antiformal stack structure, eventually cutting across the forearc crust (Central Chile: Glodny et al., 2005; Crete: Marsellos et al., 2010). Asperities at the slab surface (such as seamounts, extensional allochtons, plateaus) may also undergo stacking, leading to the formation of a composite, interface-parallel body separating the downgoing slab from the forearc lower crust or mantle wedge, with implications on stress and coupling distribution near the downdip end of the seismogenic zone (e.g.,Menant et al., 2018).

\subsection{Detachment and underplating during subduction infancy}

One of the best examples of (long-term) mechanical coupling along the plate interface is provided by metamorphic soles (Agard et al., 2016; Fig. 5), which represent pieces of crust stripped from young slabs and underplated beneath the (nascent) mantle wedge shortly after subduction initiation (Wakabayashi and Dilek, 2000).

These metamorphosed pieces of crust, scraped off and underplated over 1-2 Myr (Rioux et al., 2016), have very comparable characteristics worldwide: the $10-100 \mathrm{~m}$ thick slices of high temperature soles (HT soles) formed at $800 \pm 50{ }^{\circ} \mathrm{C}$ and $1 \pm 0.1 \mathrm{GPa}$ are made of mafic crust, whereas later, lower temperature soles (LT soles, down to 600 ${ }^{\circ} \mathrm{C}$ ) have an increasing sedimentary component (Casey and Dewey, 1984). Progressively shallower portions of the slab are thus being scraped off diachronously across a few Myr and underplating is stepwise (Fig. 5a; Soret et al., 2017a,b). The mantle above is strongly deformed across $\sim 0.5-1 \mathrm{~km}$ during HT sole formation (Fig. 5b,c) and

a

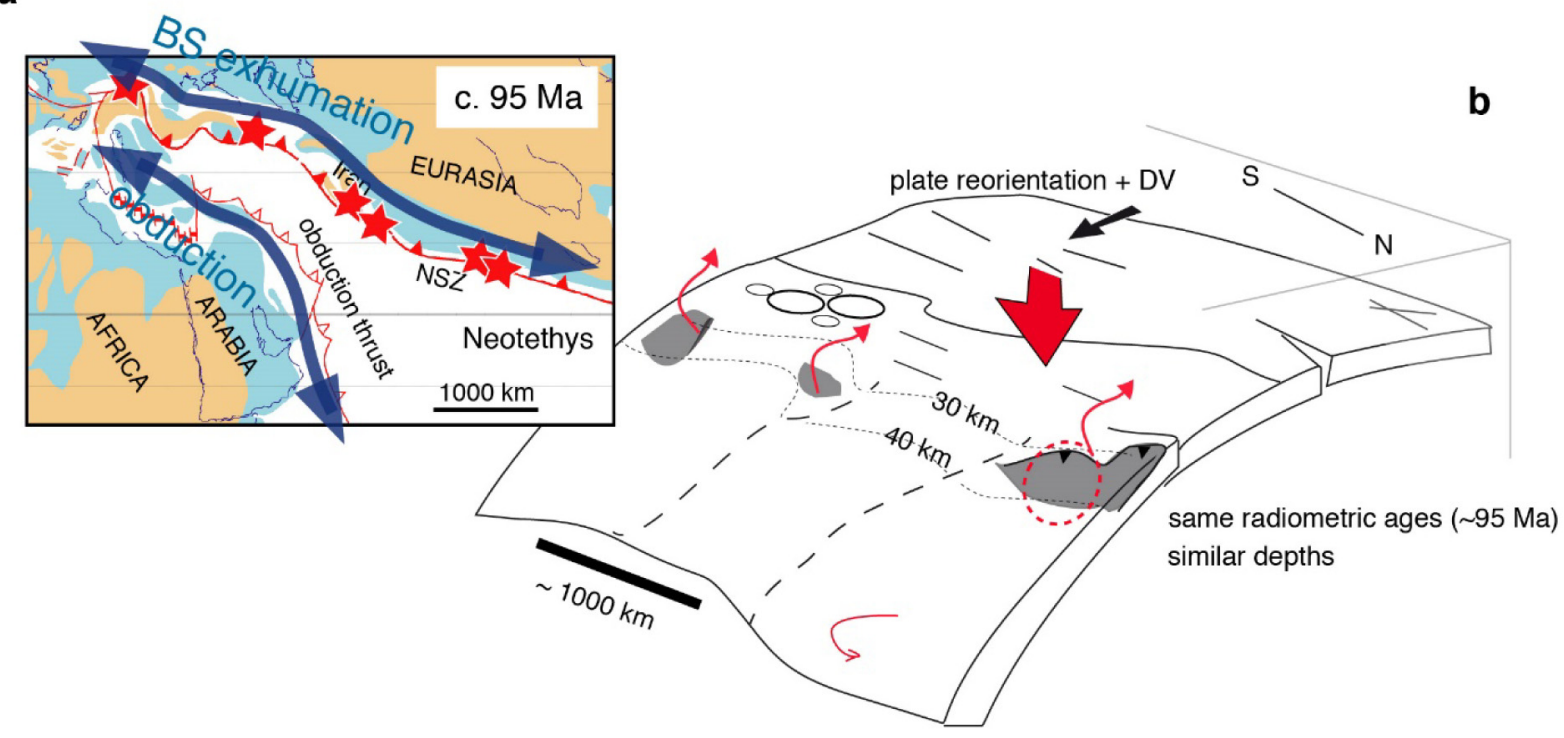

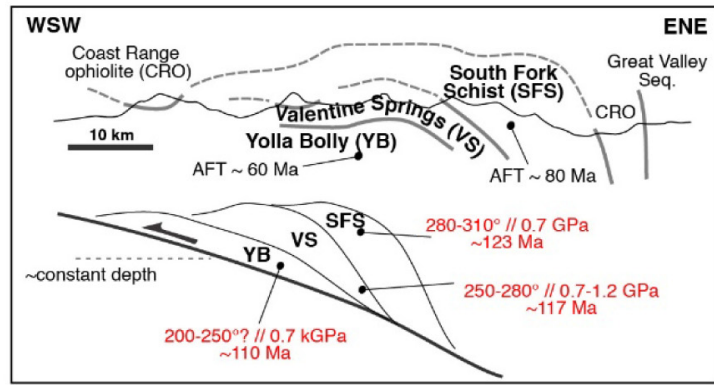

C

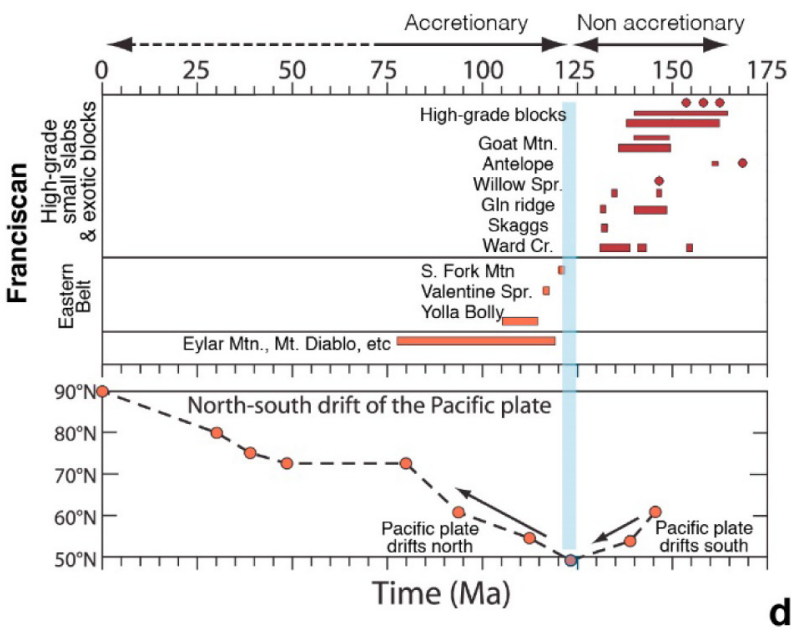

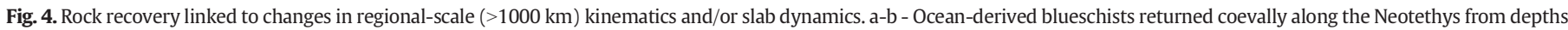

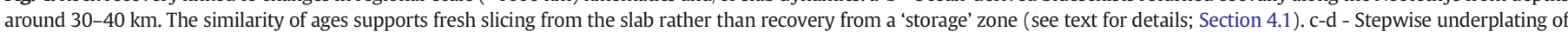

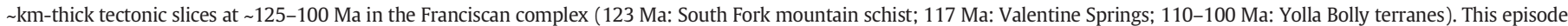

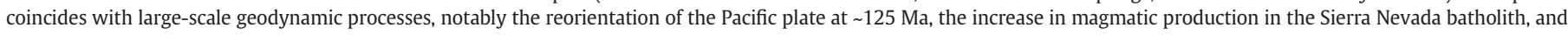
predates the period of flat slab subduction (85-45 Ma). Modified after Dumitru et al. (2010). 


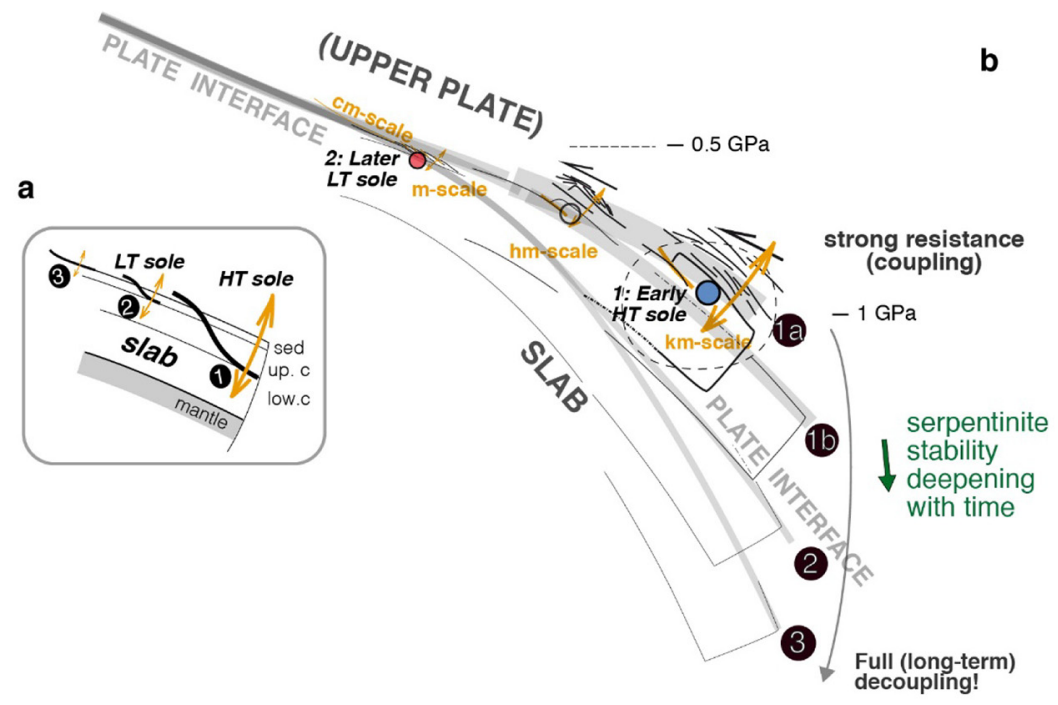

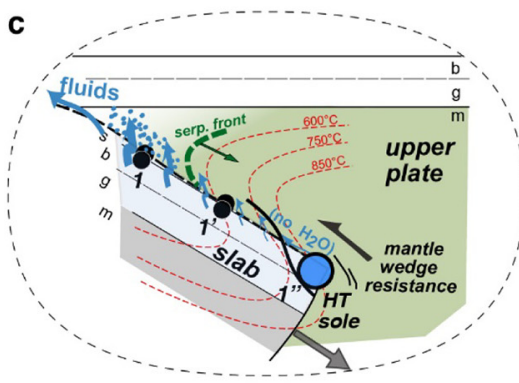

Stage 1: HT sole formation, first resistance to slab entrance

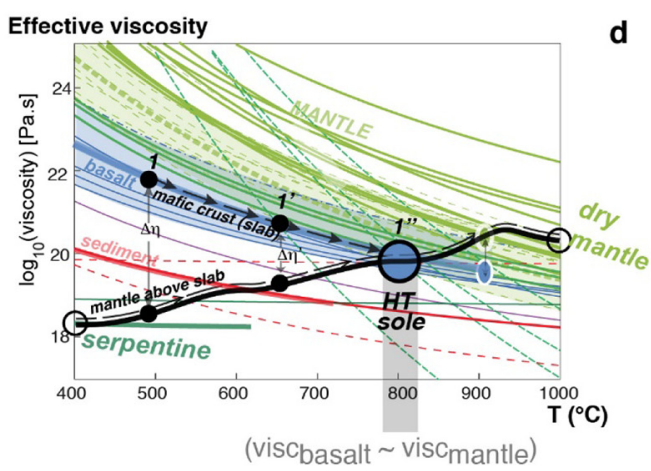

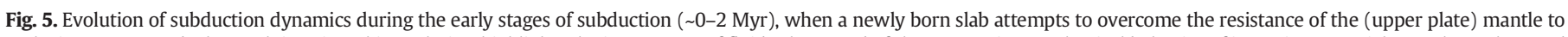

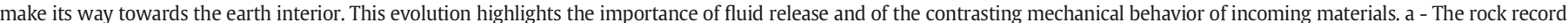

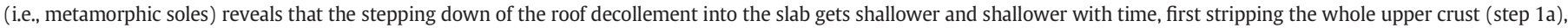

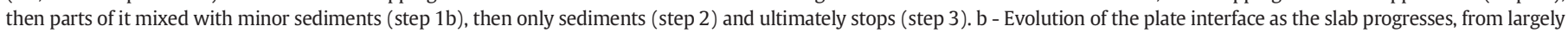

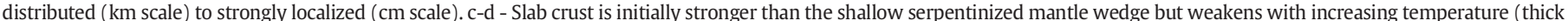

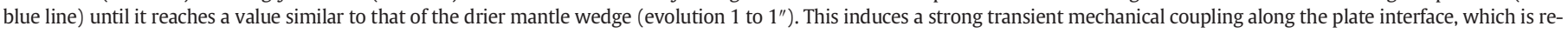

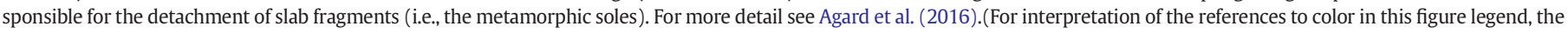
reader is referred to the web version of this article.)

partly exhumed together with the metamorphic sole. This indicates that deformation is distributed across the whole subduction interface and testifies to theexistence of a thick roof décollement during early subduction (stage 1a; Fig. 5b; Prigent et al., 2018).

In essence, metamorphic soles record initial subduction steps, during which the newly born slab attempts to overcome the resistance of the (upper plate) mantle acting as a buttress (e.g.,formation of the HT sole: Fig. 5c). Comparing effective viscosities shows that the slab crust is initially stronger than the (shallow) serpentinized mantle wedge until it reaches at depth a value similar to that of the deeper, drier mantle wedge (evolution 1 to 1 "; Fig. 5d): the detachment of metamorphic soles and welding to the upper plate marks the fact that, during a relatively short time span $(<1-2 \mathrm{Myr})$, the slab crust and the mantle wedge on top share similar viscosities (Fig. 5c,d), which induces strong mechanical coupling (Agard et al., 2016).

The cooling of the subduction thermal regime has several important consequences:

(i) at $1 \mathrm{GPa}$, the mantle wedge is initially stronger than the slab but weakens over time as it cools and as weak hydrous phases, mainly serpentinite, are progressively stable deeper and deeper (Fig. 5b), lubricating the plate interface and allowing for strain localization across an increasingly narrower zone (orange arrows in Fig. 5b).

(ii) as mantle wedge serpentinization expands further down, strong mechanical coupling can only be expected at greater depths, yet rock analogous to metamorphic soles are no longer exhumed. Agard et al. (2016) suggested that high-grade mafic blocks found in serpentinites or lower-T mélanges exhumed early during subduction history (Agard et al., 2009; Garcia-Casco et al., 2008a,b; Lazaro et al., 2009) may represent such analogues.

(iii) the stepping down of the roof décollement into the slab gets shallower and shallower (Fig. 5a,b), first stripping the whole upper crust (step 1a), then parts of it mixed with minor sediments (step 1b), then only sediments (step 2)and ultimately stops (step 3).

Metamorphic soles exemplify the role of transient mechanical coupling along the plate interface. They highlight the importance of fluid release and contrasting mechanical behavior of incoming materials, suggesting that similar mechanisms may also control the transient detachment and subsequent underplating/exhumation of HP-LT rocks in mature subduction systems.

\subsection{Detachment of tectonic slices from the slab in numerical models}

Using numerical experiments, Ruh et al. (2015); Fig. 6) investigated the effect of upper and lower oceanic plate mantle serpentinization 


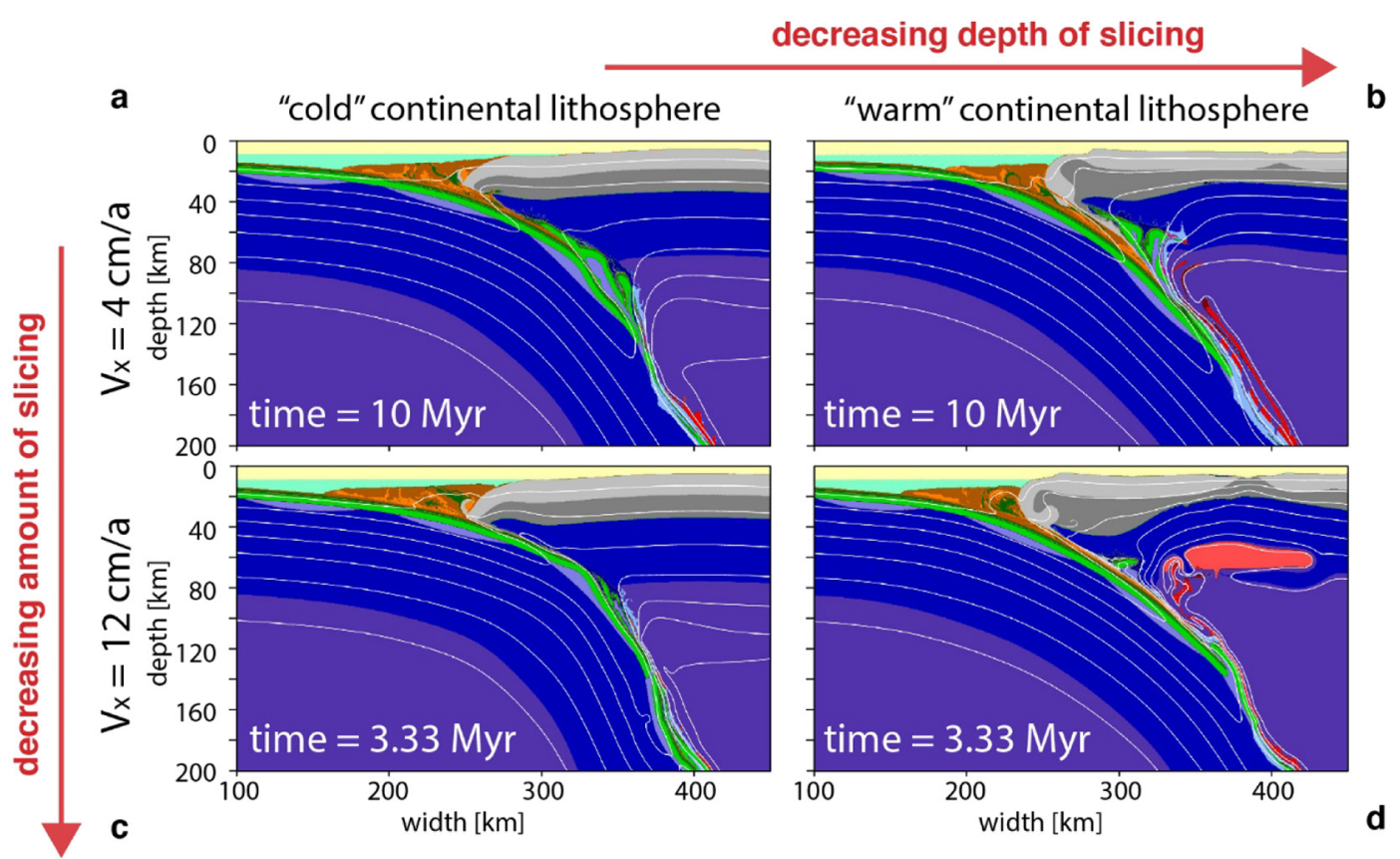

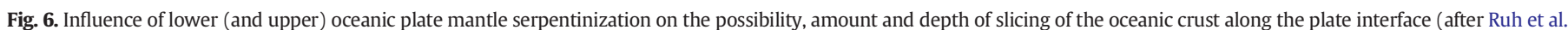

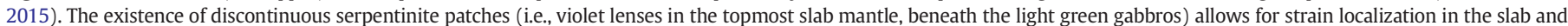

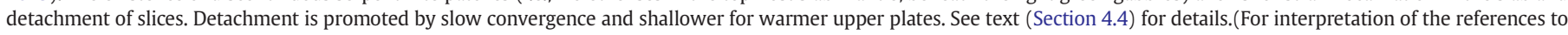
color in this figure legend, the reader is referred to the web version of this article.)

(Figs.2a and 3b; Ranero et al., 2003; Faccenda, 2014 and references therein; Emry and Wiens, 2015) on the possibility, amount and depth of detachment of the oceanic crust along the plate interface.

In the absence of oceanic mantle serpentinites, models indicate that most of the downgoing slab crust remains attached to the slab mantle and get subducted (Fig. 3 of Ruh et al., 2015; see also Angiboust et al., $2012 b$ ). This is consistent with the fact that a mechanically weak zone is needed within the slab (whether inherited or newly formed as a result of progressive strain accumulation and damage) to localize strain. Continuous serpentinization of the upper oceanic mantle, on the other hand, results in complete shallow accretion (Fig. 4 of Ruh et al., 2015; see also Vogt and Gerya, 2014b). Depending on several rheological, mechanical and thermal parameters, discontinuous, patchy serpentinization of the oceanic mantle may or not lead to effective detachment at various depths:

(i) cooler continental geothermal gradients within the upper plate enhance mechanical coupling and deeper dehydration of serpentinite, favoring deeper slicing of oceanic crust (Fig. 6a,b).

(ii) larger serpentinite patches (170 km; Ruh et al., 2015) induce shallower detachment, due to the fact that larger patches decrease mechanical coupling between the oceanic crust and oceanic mantle: decoupling within the oceanic slab (atop a patch) occurs when the slab is still at accretionary wedge levels. Tectonic slices underplated at shallow depths (i.e., $20 \mathrm{~km}$, such as the Crescent Terrane along the Cascadia subduction zone; Hyndman et al., 1990; Hirsch and Babcock, 2009) could thus derive from the presence of large serpentinized patches below the oceanic crust. Too small patches (e.g., $42.5 \mathrm{~km}$ ) do not trigger detachment, since oceanic crustal/mantle decoupling is too weak and stresses built up within the crust are insufficient for strain localization.

(iii) faster convergence velocities have a negative impact on the detachment of tectonic slices (Fig. 6a,c). A plausible explanation is that the associated colder geotherms extend the forearc serpentine stability (and lubrication) downward;

(iv) whenever oceanic crust detaches from eclogitic depths, exhumation along the serpentinized mantle wedge occurs with velocities from 1 to $10 \mathrm{~mm} / \mathrm{yr}$, i.e. comparable to natural observations (Agard et al., 2009 and references therein).

\subsection{Mechanical coupling: from long- to short-term}

The above examples allow drawing a number of general conclusions:

- the punctuated rock record (dominantly from depths $\leq 30-40 \mathrm{~km}$ to $\sim 80 \mathrm{~km}$ ) results from the fundamentally transient detachment from the slab (followed or not by underplating of channel material; Fig. $2 \mathrm{~b})$, on the order of the Myr or possibly less. Most of the fossil record originates from the downgoing plate.

- rocks/units detached likely correspond to « fresh » material: the absence of a storage zone (at least over more than a few Myr) supports the absence of an exhumation barrier/filter.

- mechanical coupling (rather than the effective slicing) chiefly controls the detachment of tectonic slices from the slab and is controlled by effective viscosities across the plate interface. It will depend on changes in strain rates, kinematics, fluid inputs and/or rock type (Figs.5 and 6).

- transient (changes in) mechanical coupling and strain localization are essential components of subduction dynamics: how rocks get detached can therefore provide useful information on active deformation processes (i.e., seismic or interseismic/geodetic coupling; Table1).

\section{Further evidence from diagnostic fossil exposures}

A systematic survey of diagnostic fossil exposures was performed to scrutinize further the rock record: the above conclusions suggest that this (through the duration and physical conditions of detachment, typical volumes, rock types, structural relationships, or the nature of the incoming plate structure) should help constrain the threshold values for 
Table 2

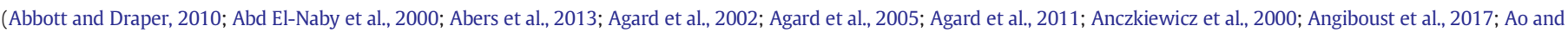

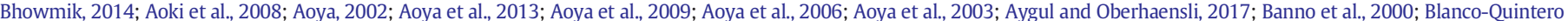

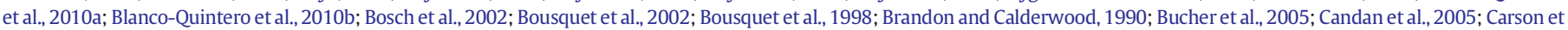

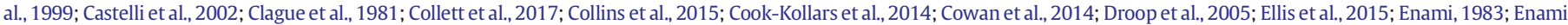

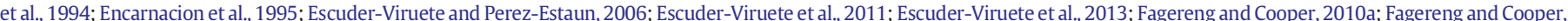

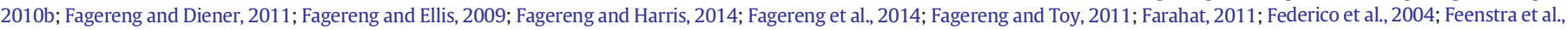

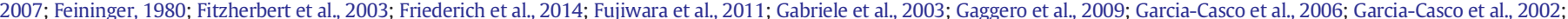

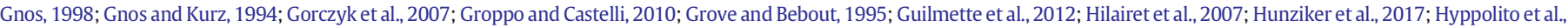

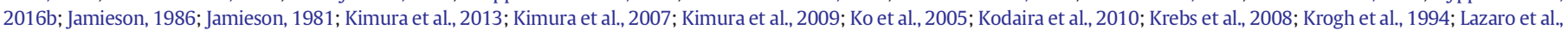

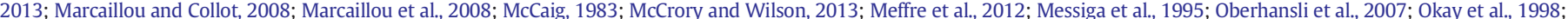

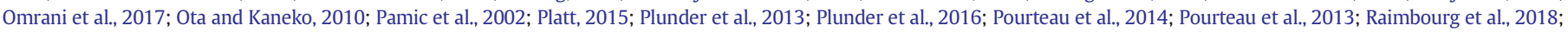

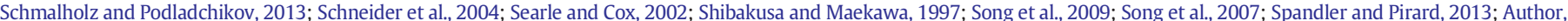

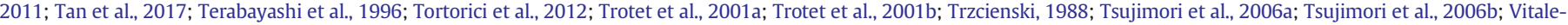

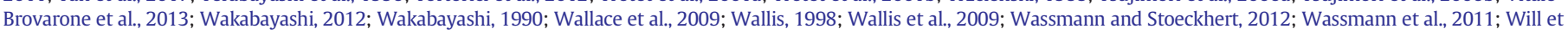
al., 1998; Willner et al., 2004; Yamato et al., 2007; Yamato et al., 2008; Zhang et al., 2007; Zhou et al., 2009).

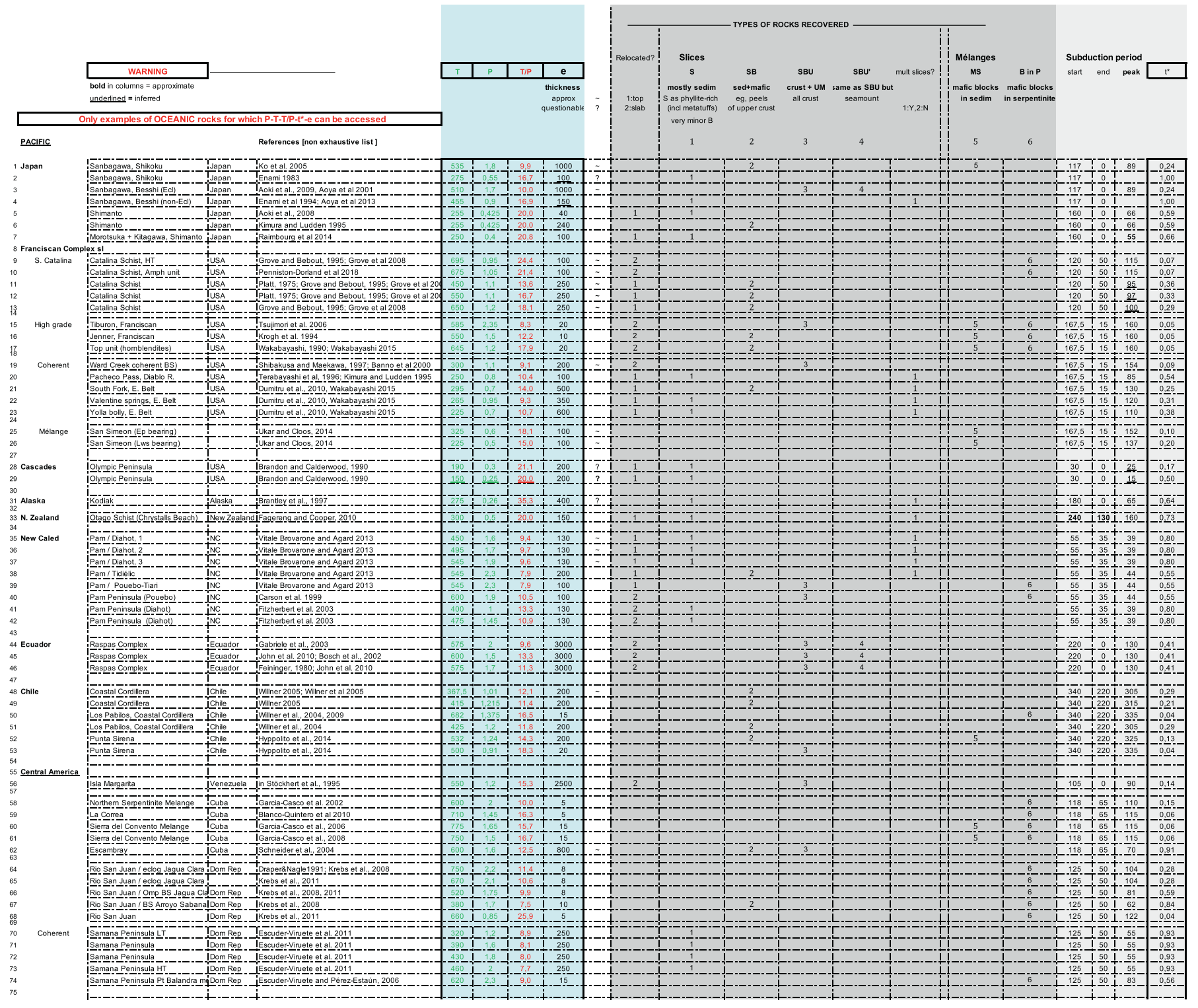




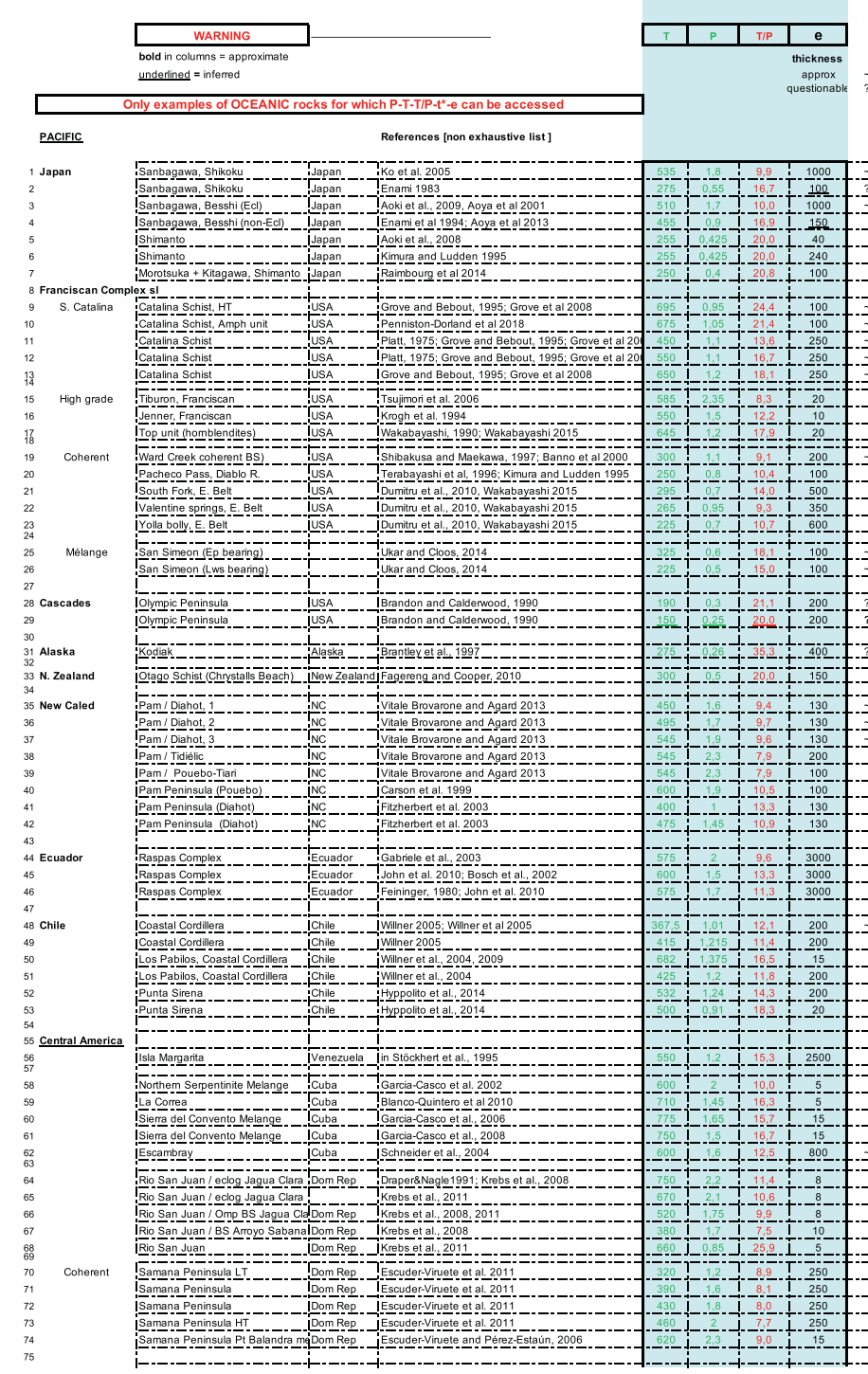

'long-term' mechanical coupling (i.e., effective viscosity and/or strain rate along the roof décollement or strain zone in the slab) but also provide constraints on short-term mechanical coupling.

\subsection{Data selection and rock types}

We selected diagnostic fossil exposures within $<\sim 500 \mathrm{~m}$ from the plate interface. This compilation encompasses $\sim 130$ oceanic examples from the Phanerozoic (e.g., Cuba, Chile, Japan, Cyclades, Turkey, Iran, W. Alps, California, N. Caledonia; Table2; Fig. 7). In order to focus on the dominant mode of subduction on Earth (i.e., sinking of oceanic lithosphere), only fragments of oceanic lithosphere are considered, i.e. slab and/or cover for which relocation with respect to the plate interface can reasonably be assessed (e.g., Scarsi et al., 2018). The present compilation can be seen as an extension, to greater depths, with more variable settings and more information (e.g., rock types, fragment types, thicknesses), of the study of peeled oceanic slabs by Kimura and Ludden (1995; 'greenstone slabs covered by cherts') or the compilation of Agard et al. (2009). Some examples are common to the selection of Penniston-Dorland et al. (2015), but examples with continental subduction were discarded (except two examples of oceanic fragments

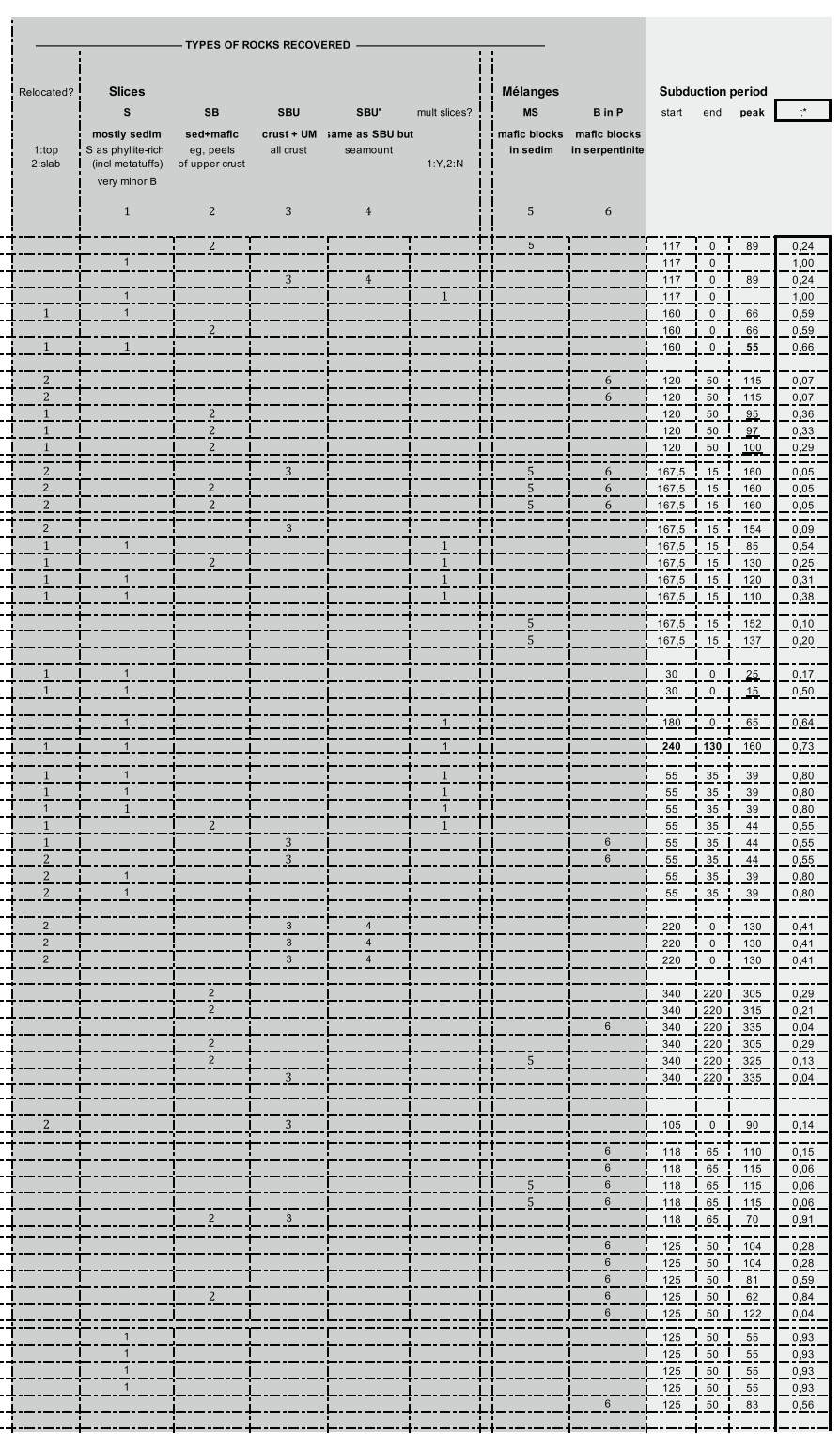

possibly transitioning to very stretched outboard margins: Corsica, Crete). Estimating the frequency of the different types of rocks/units is fraught with uncertainties due to uneven exposure of the geological record or sampling biases (e.g., studies concentrated on spectacular localities, or pieces from 0 to $\sim 15-20 \mathrm{~km}$ depth not identified as once subducted due to the scarcity of index minerals).

Overall, two main groups can be distinguished:

(1) Tectonic slices (Fig. 7a). These can be made of metasediments only ('S' type; Table. 1). Examples of sediment-dominated packages comprise the Schistes Lustrés calcschists and metapelites, Franciscan metagraywackes, Shimanto mélanges and tectonic slices, or shallowly subducted fragments of Olympus Mts or Otago schist (Table2). Another type corresponds to metasediments with metamorphosed mafic rocks usually alternating in varying amounts ('SB' type; Fig. 7a). Thin repeated slices of SB type are typically made of cherts and basalts (Kimura and Ludden, 1995; W. Turkey; parts of Sambagawa; Franciscan: shallow Marin Headlands or deeper Ward Creek; Meneghini and Moore, 2007) or alternating graywackes and basalts (Franciscan complex; Kimura and Ludden, 1995). Large 

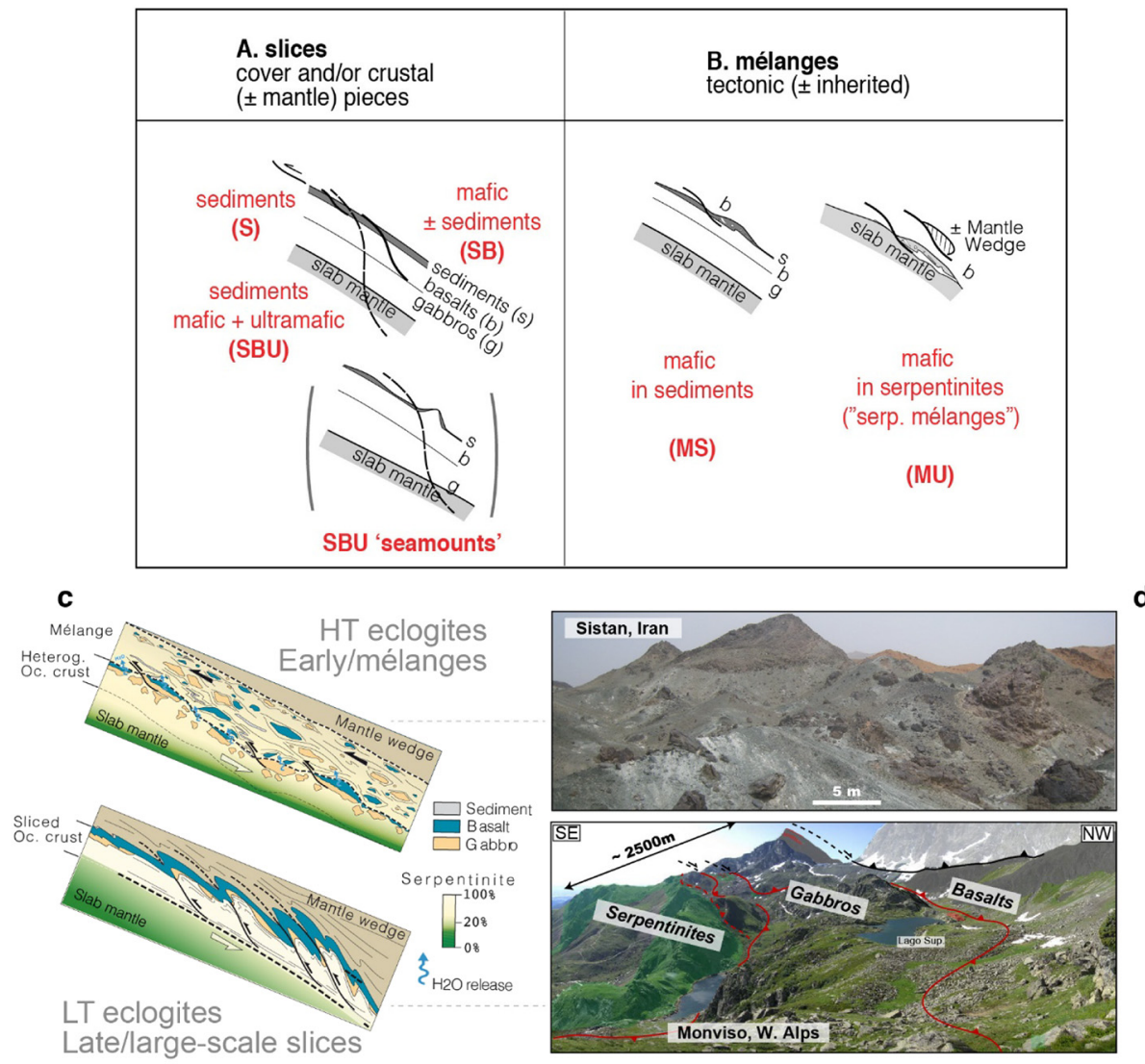

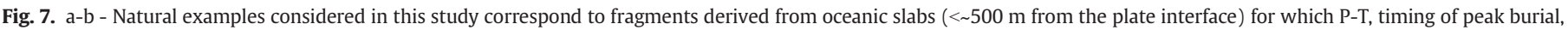

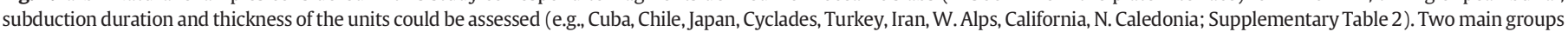

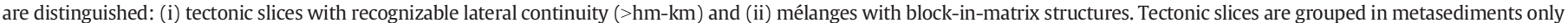

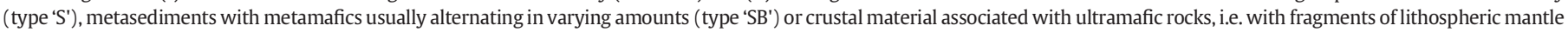

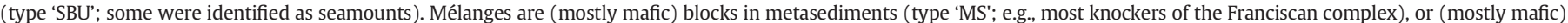

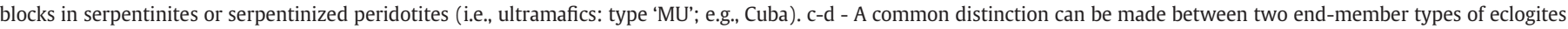

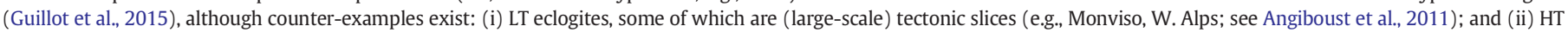
eclogites sampled from (early) mélanges (e.g., Sistan example; after Angiboust et al., 2013). See Discussion (notably Section 6.2).

basalts exposures are found in seamounts or subducted ridges (e. g., Ecuador, SWIran, locally Sambagawa).

A third type corresponds to crustal material associated with ultramafic rocks, i.e. with fragments of lithospheric mantle ('SBU' type). Ultramafic fragments may be of variable sizes, from the hm- to km-scale (Angiboust and Agard, 2010; Grove et al., 2008; John et al., 2010). Exposures with serpentinites and/or metasomatic mafic-ultramafic horizons along faults only were not considered as part of this category (i.e., Diahot unit, New Caledonia; Cluzel et al., 2001; Vitale-Brovarone et al., 2018).

High-temperature metamorphic soles (Section 4.2) range within tectonic slices of SB type, but were distinguished on the plots (e.g., red dots in Fig. 8b): though mainly made of metamorphosed mafic rocks and only minor metasediments, relative proportions can be difficult to assess, as sediments (and to a lesser extent basalts) may have partly melted away (see discussion in Soret et al., 2017a,b).

(2) Mélanges (Fig. 7b) are block-in-matrix units with matrix/block ratio typically > 50 vol\% (Grigull et al., 2012; Yamaguchi et al., 2012). A first type of mélange is represented by blocks in metasediments (type 'MS'; e.g., most knockers of the Franciscan complex), whereas a second type, perhaps more frequent, corresponds to blocks in serpentinites or serpentinized peridotites (i. e., ultramafics: type 'MU'; e.g., Cuba; Table2). To which extent the characteristics of these mélanges are controlled by inherited, primary sedimentary features (e.g., Festa et al., 2012; VitaleBrovarone et al., 2014) is a case by case study (e.g., Wakabayashi, 2017). Some of the mélanges, for example, correspond to strongly deformed tectonic slices, as suggested by the progressive dismantling observed in sedimentary series or SB mixtures in shallow environments (e.g., Shimanto, SWJapan; Chrystalls Beach, N. Zealand). This is the case in SW Zagros, where metabasalt ridges ( $100 \mathrm{~m}$ thick by $500 \mathrm{~m}$ long) metamorphosed at $\sim 55 \mathrm{~km}$ depth are now 'floating' in a serpentinite matrix (Seghin unit; Agard et al., 2006; Angiboust et al., 2016).

As an example of the difference between tectonic slices and mélanges, two end-member types of tectonic settings can be opposed within the global diversity of eclogite exposures (Agard et al., 2009; Guillot et al., 2015; Fig. 7c,d): (i)LT eclogites commonly recovered as (late) large-scale tectonic slices and more rarely in mélanges (Tsujimori and Ernst, 2014), whereas (ii) HT eclogites dominantly sampled from (early) mélanges. Potential explanations will be addressed in the discussion (Section 6.2).

Parameters considered here are: 
a
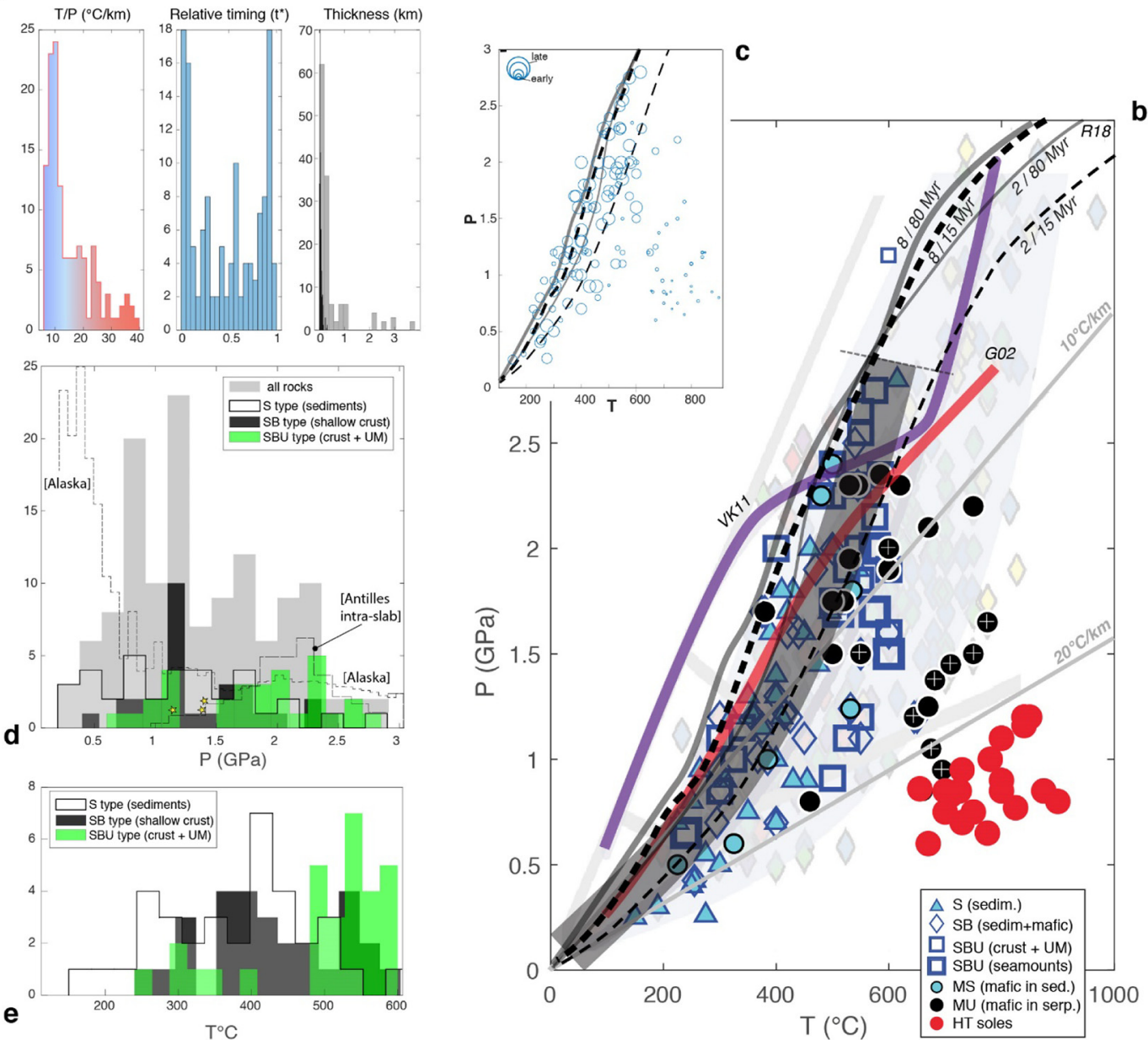

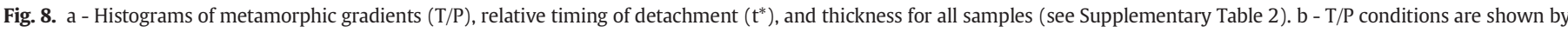

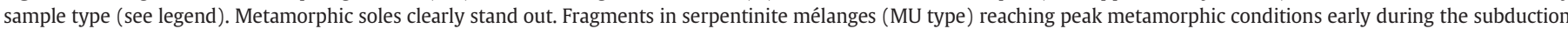

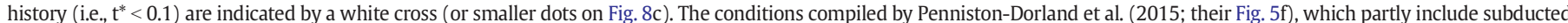

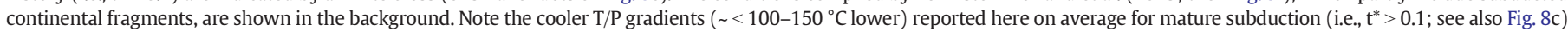

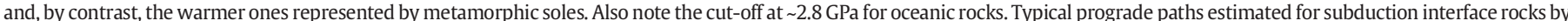

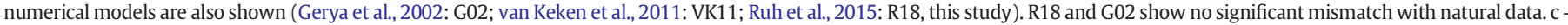

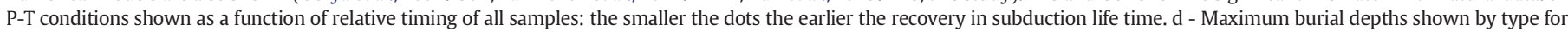

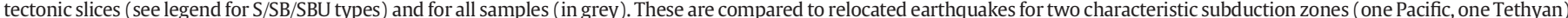

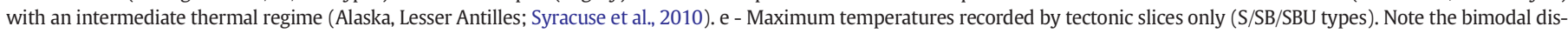
tribution for SB and SBU. The MU type would plot towards higher temperatures (see black dots on Fig. 8b).

- the age of peak pressure equilibration (peak burial), which corresponds to the age of detachment. The timing of detachment normalized to subduction lifetime is noted $\mathrm{t}^{*}\left(0<\mathrm{t}^{*}<1\right)$.

- thickness: data is very disparate and thickness is rarely estimated. The only systematic study is the one by Kimura and Ludden (1995), but for specific shallow slices $(<\sim 25 \mathrm{~km})$. This study extends the approach to the whole fossil record. Unless specifically reported, estimates come from published maps and sections, and unpublished field inspection. We report the thickness of individual fossil fragments, whether large pieces of crust or blocks in matrix. For tectonics slices, particularly metasediments, some could represent stacks (despite attempts to disentangle individual slices or mélanges), so that thickness estimates should be taken as maximum values.

- the nature of sediments (deep-sea, trench or both) or crustal type (basalts only or with some plutonic bodies) are indicated in Table2 whenever possible. The latter characteristic may not be very important since it is highly dependent on ocean type.

- the homogeneous or heterogeneous character of the mafic/ultramafic fragment (i.e., fast- or slow-spreading).

- the age of incoming material. This is however rarely known with certainty, except for some cases such as the Meso-Cenozoic Pacific subduction.

- whether they might represent more buoyant material (e.g., ridge, nascent arc), or their recovery be associated with continental subduction or a slowing down of subduction.

\subsection{Characteristic trends in pressure, temperature, T/P gradient, thickness} and relative timing of recovery

The data compiled (see also Table2) are displayed as histograms of metamorphic gradients (T/P), timing of detachment $\left(\mathrm{t}^{*}\right)$, and thickness (Fig. 8a). Pressure and temperature conditions are shown by sample type (Fig. 8b) and timing (Fig. 8c), and compared with calculated thermal profiles (Gerya et al., 2002; van Keken et al., 2011; G02 and VK11 in Fig. 8b). Thermal profiles were also calculated for plate convergence rates of 2 or $8 \mathrm{~cm} / \mathrm{yr}$ and subducting plate ages of 15 or $80 \mathrm{Myr}$ based on the method of Ruh et al. (2015); R18 in Fig. 8b and C). In Fig. 8d, maximum burial depths are shown for the S/SB/SBU type tectonic slices (and for all samples in grey; Fig. 8d) and compared to relocated earthquakes for two characteristic subduction zones with an intermediate 
thermal regime (Alaska, Lesser Antilles; Syracuse et al., 2010). In Fig. 8e, the range of temperatures is compared for the S-SB-SBU rock types.

More than half of the metamorphic gradients lie $<12{ }^{\circ} \mathrm{C} / \mathrm{km}$, with a peak at $9.5^{\circ} \mathrm{C} / \mathrm{km}$. Fig. 8b-c reveal the existence of three main types of T/P gradients: $\sim 25^{\circ} \mathrm{C} / \mathrm{km}$ for subduction initiation, $\sim 15-17^{\circ} \mathrm{C} / \mathrm{km}$ for early subduction and $8-12{ }^{\circ} \mathrm{C} / \mathrm{km}$ for steady subduction. A difference can be noted within the MU category: early ones (black dots with a cross; Fig. 8b; dashed ellipses: Fig. 9a,b) show a higher T/P than the later ones (see also Fig. 8c). Fig. 9c outlines the change of T/P gradient with timing of recovery (by contrast, there is no change in pressure: Fig. 9d).

Oceanic rocks are returned from maximum depths of $\sim 85 \mathrm{~km}$ (2.8 GPa; Fig. 8b). There is no difference between the mélange types (MS and MU) in terms of maximum burial, but mélanges with matrix serpentinite (MU) record slightly higher pressure values on average (1.5-2.3 GPa).

Histograms by type as a function of peak pressure (i.e., depths; Fig. 8d) reveal a difference between metasediment-dominated and types with mafic fragments. Type $\mathrm{S}$ is rarer beyond $~ 1.5-2 \mathrm{GPa}$. For type SB, the peak of recovery of slices (with basalt and chert) lies at $\sim 1 \mathrm{GPa}$. A pressure gap (such as noted by Plunder et al., 2015, or Groppo et al., 2016; Fig. 3b) is only observed for type SB and SBU, between 1.2 and 1.7-1.8 GPa (approx. 40 and $55 \mathrm{~km}$ ). A second peak is observed for SBU at $2.3 \mathrm{GPa}(\sim 70 \mathrm{~km})$.

These burial depths can be compared with the seismicity of two active subduction zones for which earthquakes were relocated with a precision of a couple of km (Alaska: by double-difference, courtesy M. Bostock; Lesser Antilles after Paulatto et al., 2017), hence with a comparable or lower uncertainty than the estimates of metamorphic pressure (whereas EQ locations in the ISC catalogue, for example, tend to be larger). The range of depths reached by SBU broadly coincides with the envelope of intermediate-depth seismicity. The SB and SBU types show a bimodal distribution with respect to temperatures (in someway comparable to the plot as a function of depth, considering the average T/ P gradient is $\sim 9.5^{\circ} \mathrm{C} / \mathrm{km}$ ), which match the temperature range of the brittle-ductile transition $\left(\sim 350{ }^{\circ} \mathrm{C}\right)$ and of partial de-serpentinization $\left(550{ }^{\circ} \mathrm{C}\right)$.

The timing of recovery of these rocks ( $t^{*}$; Fig. $8 \mathrm{a}$, middle panel) is highly variable but shows that early and late recovery dominate (grey overlays on Fig. 9b-d). Intermediate peaks show that incidental recovery is also significant (Agard et al., 2009), as further illustrated by thedispersion of points along the vertical axis in Fig. $9 \mathrm{~b}-\mathrm{d}$. As mentioned above, early ones have (quite logically) the highest T/P (Fig. 9b). Fig. 8c also shows that steady subduction is rapidly reached ( $<\sim 5 \mathrm{Myr})$.

There are a few long-lasting systems with underplating $<0.5-$ $0.8 \mathrm{GPa}$, along the North American margin (Franciscan, 123-80 Ma; see Section 4.1) and SWJapan subduction zones (i.e., the successive Chichibu-Sambagawa-Shimanto belts, from the Late Jurassic to early Cenozoic). For these examples deep recovery exists too, but only early on and in mélanges (MU or MS).

Rock fragments are mainly metasediments and metabasalts, and only rarely gabbros, suggesting that what is sampled corresponds mostly to the top of the slab, except for SBU fragments. The contrast between the fairly anhydrous gabbros and the more strongly hydrothermalized and therefore hydrated basalts probably allows for a major tectonic decoupling between the two. In general, returned fragments correspond to rather thin slices (Fig. 8a, right panel), in line with former findings of Kimura and Ludden (1995; <200 m; black overlay), though hinting towards higher values ( $<400 \mathrm{~m}$; see also Fig. 9e).

Thicker types are slab pieces comprising crustal and lithospheric fragments (SBU; Fig. 9e-h), and are restricted to $<4 \mathrm{~km}$. Maximum thickness for the metasedimentary type (S)is $\sim 700 \mathrm{~m}$. No blocks or units thicker than $\sim 100 \mathrm{~m}$ are found for the highest temperature pieces (Fig. 9f) or T/P gradients (metamorphic soles plus early mélanges; Fig.
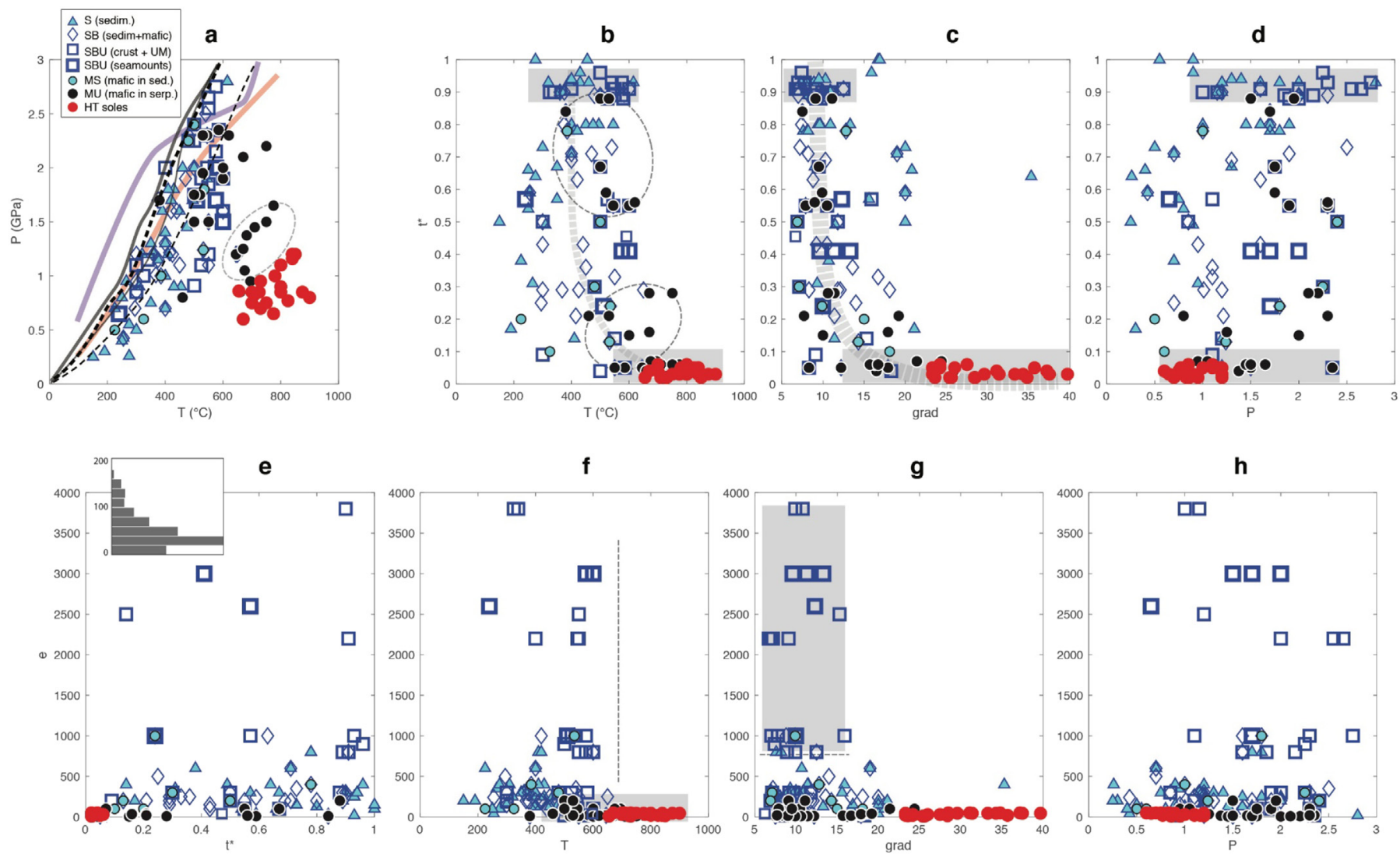

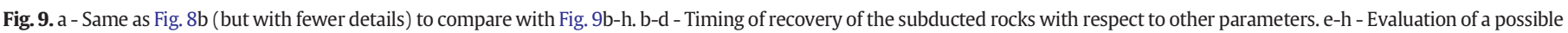
relationship between thickness and t*, T, T/P or P. See text for detailed comments. 
9g). The underplating of metamorphic soles, however, probably involves significant thinning (Soret et al., 2017a,b). This may also be the case of units involving only metasediments (Plunder et al., 2012; Fagereng, 2013, in Rowe et al., 2013). No correlation is observed between peak burial and thickness.

As pointed out by Grigull et al. (2012), subduction mélanges are such that matrix (serpentine or sediments) largely dominates over blocks. Block sizes of MU type are nevertheless somewhat larger when mélanges are less chaotic (Despaigne-Díaz et al., 2017).

No major difference exists between the subducted material types identified by Maruyama et al. (1996), i.e. 'type B' represented by Japan and the Franciscan complex ('active continental-margin protoliths in an accretionary complex characterized by bedded chert, MORB and ocean-island basalts, reef limestones, and graywackes') or the 'type A' by Samana Peninsula and the Western Alpine Schistes Lustrés ('passive-margin protoliths characterized by platform-type carbonates, bimodal volcanics, and peraluminous sediments'), except for slight differences in maximum burial, mostly $<2$ GPa for type A and mostly $<1 \mathrm{GPa}$ for type B.

\subsection{Present-day examples}

Evidence for present-day detachment and/or underplating is scarce. Geophysical imaging is blurry, particularly in the 10-30 km depth range (Saffer and Wallace, 2015), and only a handful examples have so far been reported (see below and location on Fig. 1b). There could be more since local seismic networks have been deployed only across a limited number of subduction zones (e.g., Toda et al., 2008). However, with only a few percents detached in the rock record (Section 3), one should expect less than $\sim 500-1000 \mathrm{~km}$ coeval detachment along the $55,000 \mathrm{~km}$ of active subduction zones, which may easily go unnoticed.

Suspected underplated pieces of crust \pm mantle (S or SBU type, which may or may not ultimately be recovered) include:

- North and South America: (i)Yakutat: $\sim \mathrm{km}$ of sediments underplated at $\sim 35 \mathrm{~km}$ depth (Chuang et al., 2017); (ii) Cascadia: 5-10 km thick at $25 \mathrm{~km}$ (Calvert, 2004); (iii) Costa Rica: 3-4 km at $\sim 15 \mathrm{~km}$ depth (St Clair et al., 2016).

- Japan: (i)SEJapan (Kanto region): 10 km thick, $25 \mathrm{~km}$ by $100 \mathrm{~km}$ fragment (Toda et al., 2008) and km-thick sedimentary slices at 10-15 km depth (Kimura et al., 2010); (ii) Nankai: 10-15 km of underplated material at $\sim 30 \mathrm{~km}$ depth (Kodaira et al.).

- Sumatra: 10-15 km at 30 km depth (Singh et al., 2008, 2011).

Return of HP-LT rocks in active subduction zones are scarce too and do not (yet) bring much information on these processes: fragments returned by shallow serpentinite diapirs were metamorphosed long before exhumation (e.g., 48 Ma for the Marianas; Maekawa et al., 1993; Pabst et al., 2012; Tamblyn et al., 2018), suggesting that these pieces stagnated at sub-surface depths before being plucked by the diapirs.

\section{Discussion}

6.1. Conditions of rock recovery: pressure, temperature, $T /$ P gradients, thickness and timing

\subsubsection{T/P gradients: no significant overpressures}

Fig. 8 demonstrates that very consistent T/P gradients are observed for all rocks recovered significantly after subduction initiation (Fig. 8c). This observation rules out significant overpressure (Schmalholz and Podladchikov, 2014; Yamato and Brun, 2017; Marques et al., 2018), as already hinted by Warren (2013) - or would imply systematic overpressure in a very consistent way for all rocks.

\subsubsection{Trustable natural probes for the plate interface}

Our compilation suggests that P-T trajectories of recovered rocks are those expected for subduction interface conditions. Doubts were cast by the suggestion that rocks may preserve higher $\mathrm{T}$ than numerical models (Penniston-Dorland et al., 2015; van Keken et al., 2018). Yet the present compilation shows that the high T/P steady state gradients are less dispersed than suggested by these authors and that rocks may not be significantly warmer than models (e.g., the steady metamorphic T/P gradient and that of Gerya et al., 2002 are close; Fig. 8b), especially given uncertainties on the models. Predictions from the four thermomechanical models calculated here (R18; Figs.8b,c) match in fact quite well the rock record. The consistency of T/P gradients for oceanic remnants (Fig. 8a,b) also suggests that the thermal impact of later exhumation-related processes is only moderate. The apparent discrepancy in Penniston-Dorland et al. (2015) probably comes from the fact that the timing of recovery $\left(t^{*}\right)$ was not considered and that subducted continental fragments were considered along with oceanic rocks in their compilation (as well as in Brown and Johnson, 2018), for which higher temperature and greater thermal imprint may result from subduction slow down and exhumation (e.g., O'Brien et al., 2006). In theory, part of the T mismatch (if any) could arise from the fact that rocks were not located exactly along slab tops or may correspond to minor additional T sources (e.g., shear heating, though likely $<50{ }^{\circ} \mathrm{C}$; van Keken et al., 2018). A significant contribution from rock convection within a 'subduction channel' would conflict with the punctuated character of exhumation, and its independence from convergence rates (Agard et al., 2009; Penniston-Dorland et al., 2015).

\subsubsection{Maximum depths}

Fig. 8b shows that there is a depth cut-off at $\sim 2.8 \mathrm{GPa}$ : beyond that point, no deeper oceanic rocks are recovered in general (in line with Agard et al., 2009; Whitney et al., 2014). The only exception so far (Fig. 8b) is a 10-50 m thick UHP slice (Lago di Cignana; Reinecke, 1998), from the Zermatt-Saas unit in the W. Alps, equilibrated at 3.2 GPa and $600{ }^{\circ} \mathrm{C}$ (Frezzotti et al., 2011; Groppo et al., 2009). This occurrence nevertheless lies within the domain where a $50-50 \%$ mixture of metabasalt and serpentinite (as reported throughout the ZermattSaas unit; Angiboust and Agard, 2010) is more buoyant than the surrounding mantle (see Fig. $3 \mathrm{~b}$ ). Pieces comprising only serpentinites, equilibrated at similar depths, have also recently been reported (Luoni et al., 2018). Rocks recovered from greater depths in other compilations are all continental.

Tentative explanations for this depth cut-off beyond 2.8 GPa include, separately or combined (i)density increase (rocks become too dense with respect to the mantle: Agard et al., 2009; Fig. 3b), (ii) slab density and effect on slab pull (Angiboust and Agard, 2010; Duesterhoeft et al., 2014) and (iii) viscous recoupling processes dragging down rocks irreversibly into the mantle once serpentine is no longer stable (Syracuse et al., 2010; Wada and Wang, 2009). Mechanical recoupling at depth, invoked by numerical models to match heat fluxes (Wada and Wang, 2009; Syracuse et al., 2010; Abers et al., 2017), is inherently required by plate tectonics. Cold subduction zones, where serpentinite could may reach 100-120 km depth (Reynard, 2013; van Keken et al., 2011), may extend recovery somewhat deeper (such as for the Lago di Cignana exposure from the W. Alps cold subduction).

\subsubsection{Preferential depths for recovery?}

Although similar depth peaks are observed as in Plunder et al. (2015) and Groppo et al. (2016), the distribution appears less clustered in our exhaustive compilation (Fig. 8d, grey histogram), with peaks at $\sim 25-35 \mathrm{~km}, 55-60 \mathrm{~km}$ and $80 \mathrm{~km}$. Outstanding features are the large overall peak at $25-35 \mathrm{~km}$ and the sharp drop in recovery beyond $80 \mathrm{~km}$. Lesser recovery in between the peaks may in part relate to differences in rock type (these differences can also be seen in single localities: e.g., Krebs et al., 2011): (i)slab fragments (SBU type) mostly detach in the depth range of intermediate-depth intraslab earthquakes, when 
comparing depths with seismicity for two subduction zones with intermediate thermal regime (Fig. 8d; Alaska: Pacific type; Lesser Antilles: Tethyan type); (ii) the SB-SBU types also probably detach at non-random temperatures (Fig. 8e); (iii) metasediments, by contrast, show no clustering at all.

Some of the data dispersion may well reflect the variability of thermal regimes and therefore of decoupling/serpentinization depths in the mantle wedge (from 55 to $110 \mathrm{~km}$; van Keken et al., 2011). Since serpentinization is $<20 \%$ for cold subduction (Abers et al., 2017), one may also anticipate the presence of an only thin serpentine horizon in these settings which, if tectonically dismembered, would affect mechanical coupling (see Section 6.4).

Importantly, synchronous bimodal recovery from 25 to $35 \mathrm{~km}$ and $70-80 \mathrm{~km}$ is observed in the Sistan (Bonnet et al., 2018), Sambagawa (Aoki et al., 2009) and Franciscan complexes (e.g., San Simeon and W. Creek; Ukar et al., 2012). This observation suggests that increased mechanical coupling can take place coevally along the whole first $80 \mathrm{~km}$ of the plate interface, with preferential strain localization and detachment in places where mechanical coupling and viscosity contrasts are the highest (Figs.3b).

\subsubsection{Punctuated, but when and what?}

Punctuated recovery with respect to subduction history (i.e., early, late, incidental: Agard et al., 2009) points to long periods of insufficient effective detachment (thus low mechanical coupling) alternating with periods during which transient processes and/or specific boundary conditions prevail. Recovery is generally less than a few percents and rarely reaches a few tens of percent (mostly via underplating; e.g., Kimura and Ludden, 1995; Willner et al., 2005; Plunder et al., 2012), even for examples showing longer recovery (Franciscan, Japan, W. Alps, Rio San Juan; Table2).

Although mostly $<\sim 300-500 \mathrm{~m}$ (Fig. 8a), some very large fragments can be recovered, such as seamounts, thick MORB fragments, or slowspreading pieces once located near hyper-extended margins (notably in the Western Alps). However, massive transfer of channel material across the plate interface via deep diapirs, hypothesized on the basis of thermo-mechanical or geochemical arguments (see Behn et al., 2011; Codillo et al., 2018; Marschall and Schumacher, 2012; Nielsen and Marschall, 2017), has not been documented. Formation of largescale diapirs, if any, has to occur deeper down (Bayet et al., 2018; this probably holds true also for large-scale relamination in a subduction context; Hacker and Gerya, 2013). Serpentinite mélanges (BlancoQuintero et al., 2011) could nevertheless represent examples of restricted diapiric ascent during early subduction (see Section 6.2), but not in a steady state convective fashion.

Although young-warm and/or slow fragments may be recovered (van Keken et al., 2018), as for metamorphic soles at the start of subduction, this is by no means a pre-requisite: there are also many old/cold fragments, as shown by Fig. 8c (e.g., Western Alps or other Tethyan examples). Recovery is rather promoted by subduction of heterogeneous low-spreading lithosphere and/or asperities (seamounts: Ecuador; ridges: SWJapan; seafloor fragments: Lagabrielle et al., 2015). Heterogeneities are indeed essential to localize strain (Gorzyik et al., 2007; Ruh et al., 2015: Fig. 6), so that model calculations of T/P gradients with heterogeneous slab structure should be considered.

\subsection{Long-term interplate mechanical coupling}

\subsubsection{Long-term trend with subduction cooling}

The present compilation outlines the existence, superimposed on transient/occasional recovery, of a systematic long-term trend associated with subduction cooling, from metamorphic soles to HT eclogites and then LT eclogites (Figs.8c and 10). We relate this trend to an evolution of mechanical coupling, from strong to weak, across the subduction interface as subduction cools (Fig. 10, inset):
- When young and still relatively dry, the plate interface experiences strong viscous coupling as testified by underplating of metamorphic soles (Fig. 10a; Section 4.2). The effective viscosity of the plate interface is estimated to be on the order of $10^{20}$ (to $10^{21}$ ) Pa.s during these stages (Fig. 5d; Agard et al., 2016).

- During subsequent subduction cooling (first 1-5 Myr; Fig. 10b), high-temperature eclogites (or HP amphibolites) form, mostly in serpentinite mélanges (MU; Fig. 8b). These HP tectonic mélanges require significant mixing along the interface, which is favored by strongly altered and/or warm (or young) incoming lithosphere and coupling at $\mathrm{m}$-hm scale with the mantle wedge (e.g., Sistan: Angiboust et al., 2013; Cuba: Garcia-Casco et al., 2008b; Lazaro et al., 2009). Effective viscosities could be in the range $10^{19-20} \mathrm{~Pa} \cdot \mathrm{s}$. Similar conditions might prevail beneath warm subduction zones today and reflect how mechanical recoupling takes place at depths (e.g., $600-800{ }^{\circ} \mathrm{C}$ at $\sim 60-90 \mathrm{~km}$ depending on the thermal regime; Syracuse et al., 2010; Abers et al., 2017).

In the present understanding, metamorphic soles form in nascent intraoceanic subduction zones (Dewey and Casey, 2013; van Hinsbergen et al., 2015; Wakabayashi and Dilek, 2000). Their formation is less likely in the context of subduction initiation beneath a continent, since the sub-continental mantle (i.e., the future mantle wedge) is comparatively colder and more hydrated. For the same reason, we infer that the recovery of HT eclogites is less likely in ocean-continent contexts, at least for those with a cold continental geothermal gradient (see also Ruh et al., 2015).

- During steady-state subduction, the locally fluid-rich, colder (older) and weaker plate interface ( $\eta<<10^{19} \mathrm{~Pa} \cdot \mathrm{s}$ : Grigull et al., 2012; Wassmann and Stoeckhert, 2013; Freed et al., 2017) is 'decoupled' (Table1; Fig. 10c), similar to most subduction zones today. Only occasional 'accidents' (Fig. 10d) result in the detachment of metasedimentary material and, more rarely, large-scale slivers of oceanic lithosphere. These accidents are only possible if décollement horizons exist within the crust (Kimura and Ludden, 1995) and/or if the oceanic mantle is partly serpentinized (allowing for the decoupling within the downgoing slab for SBU fragments; Fig. 6; Ruh et al., 2015; Cannao et al., 2016). Some of these fragments are selectively exhumed at the end of oceanic subduction, as a result of the entrance of a buoyant continent (e.g., Agard et al., 2009). This cooling trend is recorded in the Rio San Juan fossil subduction (active from $\sim 125$ to $70 \mathrm{Ma}$; Table2), with $\mathrm{m}$-scale fragments equivalent to metamorphic soles formed at $\sim 120 \mathrm{Ma}$ (and $\sim 30 \mathrm{~km}$ ), fragments transitional between HT and LT eclogites formed at $105 \mathrm{Ma}$ (and $75 \mathrm{~km}$ ) and the later recovery, between $\sim 80$ and $70 \mathrm{Ma}$, of mostly blueschists and LT eclogites from depths of 25-35 km and $\sim 55 \mathrm{~km}$ respectively (Fig. 5 in Krebs et al., 2011). This cooling trend is also consistent with the one observed in Santa Catalina island in the Franciscan complex (Grove et al., 2008; Penniston-Dorland et al., 2018; Platt, 1975).

\subsubsection{Differences for cold or warm settings?}

Depending on thermal regime and on the thickness of the serpentinite horizon above the plate interface, we predict the following differences in the way (long-term) mechanical coupling may operate in cold or warm settings (Fig. 11):

- warm settings (Fig. 11a): variations in coupling and fluid release (and volume change) will control the possibility to embed (HT eclogite of HP amphibolite) blocks in serpentinite, possibly through fluctuations in frictional-viscous properties. This likely occurs in the depth-temperature range of recoupling, where serpentine becomes unstable $\left(\sim 550-600^{\circ} \mathrm{C}\right)$. This is consistent with blocks in MU preserving a warm $\mathrm{T} / \mathrm{P}$ record being generally eclogites rather than blueschists, and may contribute to the second peak observed at $\sim 50 \mathrm{~km}$ depth (Figs.8d and 11d). 


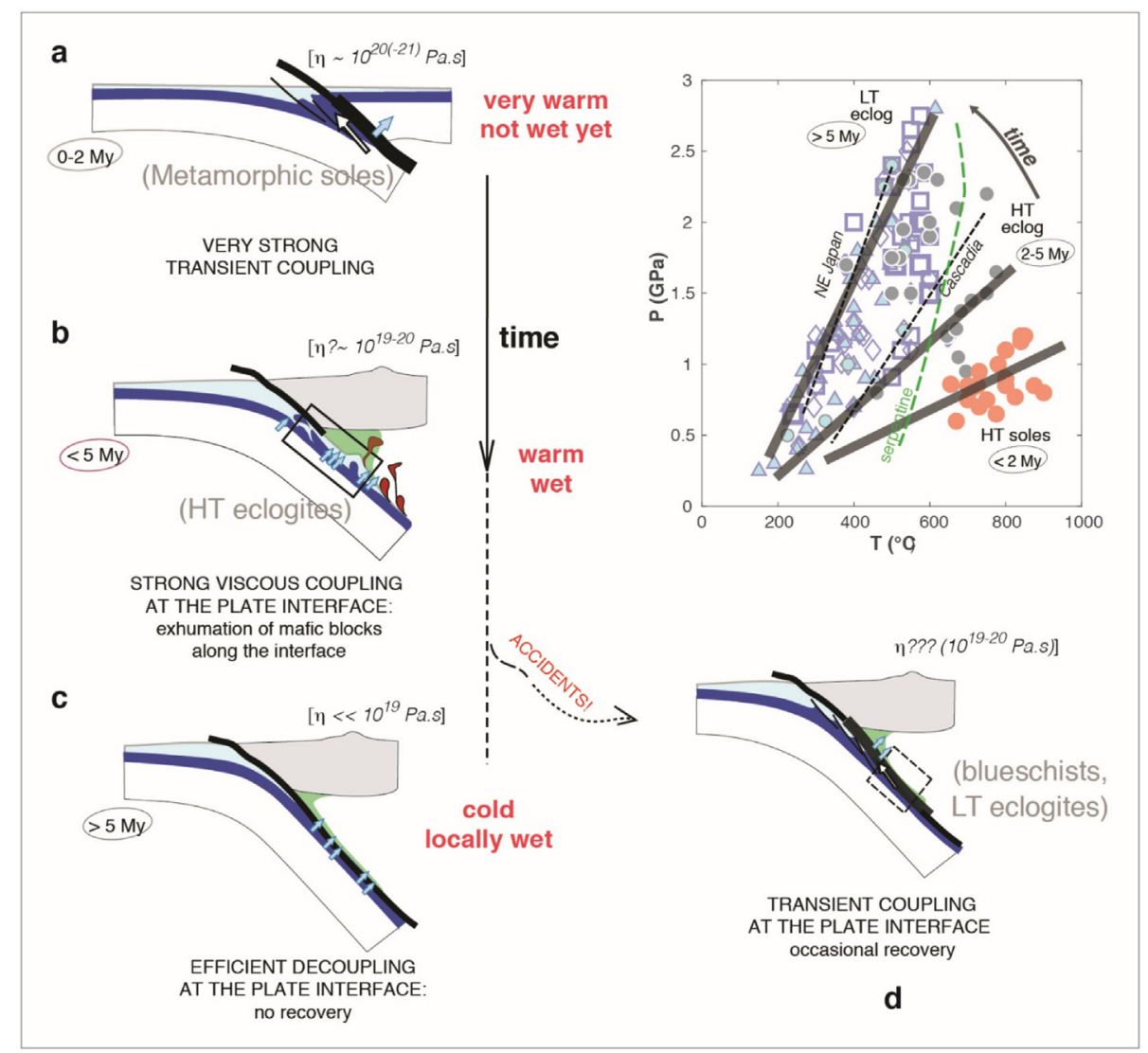

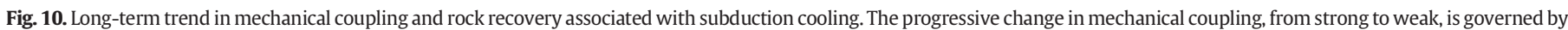

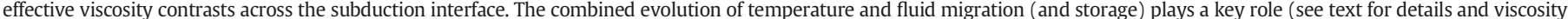

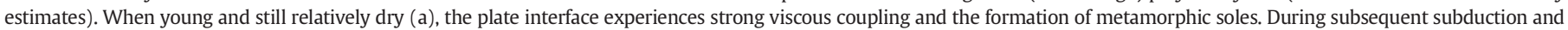

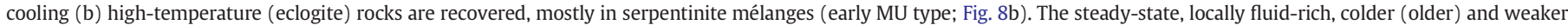
interface leads to a decoupled plate interface (c), similar to most subduction zones today, except during occasional 'accidents' (d).

- cold settings (Fig. 11b): because the downdip limit of serpentinization is almost never reached before $\sim 80 \mathrm{~km}$, transient changes in mechanical coupling will have an impact only if discontinuities preexist, with wavelength $>\sim \mathrm{km}$ scale as seen from fossil fragments (or numerical models: Fig. 6) and/or if the rheologically weak serpentinite horizon predicted to exist along the mantle wedge (Scambelluri and Tonarini, 2012; Reynard, 2013; Fig. 11b) gets rubbed away. Rheological contrasts across specific sedimentary horizons (lithologies) could modulate/control strain localization (Ikari, 2015; Vannucchi et al., 2017), explaining the distinct lithostratigraphic content of successive tectonic slices (e.g., Schistes
Lustrés: Lagabrielle et al., 2015; Deville et al., 1992; Plunder et al., 2012). In addition, in contexts where background mechanical 'coupling' is strong, changes in mantle wedge geometry and thermal structure of the cold corner, such as lithospheric thinning and/or mantle upwelling, can be expected to modulate the decoupling depth (e.g., Agard et al., 2016; Aygül and Oberhansli, 2018) and affect maximum recovery depth (in any case $<\sim 2.8 \mathrm{GPa}$ ).
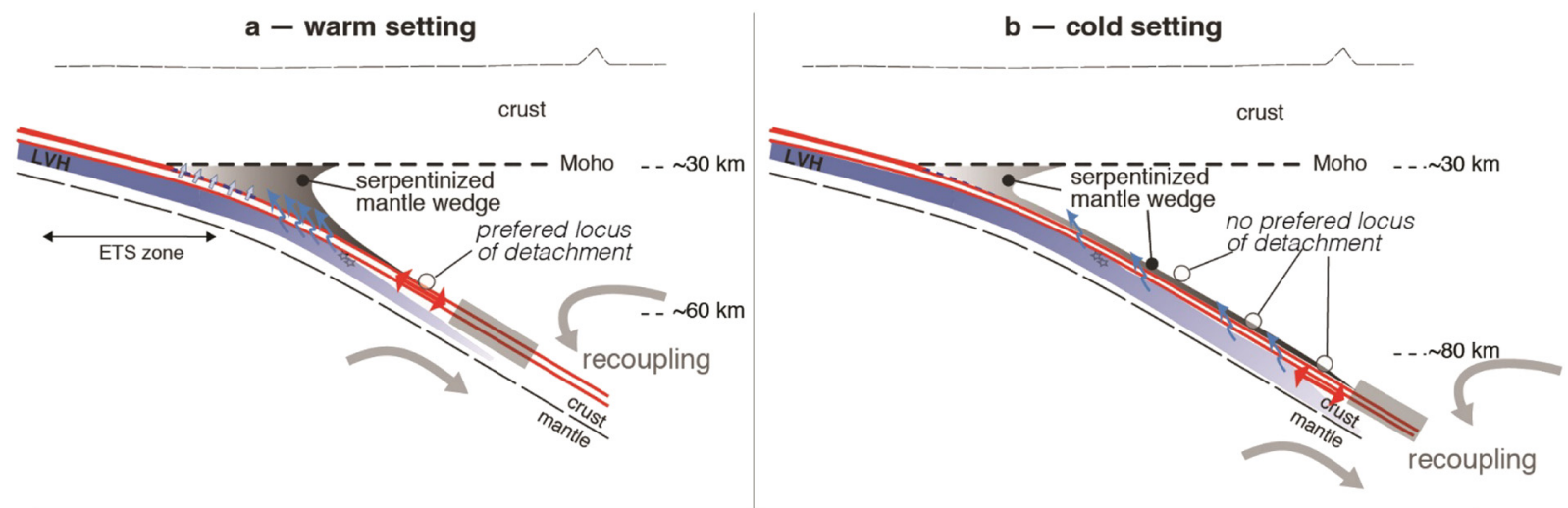

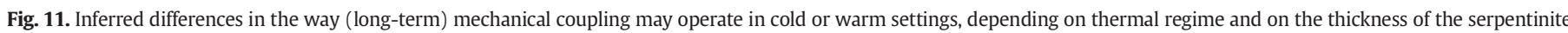
horizon above the plate interface. See text for details. 


\subsection{Subduction interface thickness}

The subduction rock record can be used to constrain interplate thickness or geometries, to determine whether the plate interface has a constant width, may decrease to almost zero or varies with time at a given depth (Shreve and Cloos, 1986; Raimbourg et al., 2007), and whether deformation is rather localized on one or multiple active faults and/or shear zones (e.g., Meneghini and Moore, 2007; Rowe et al., 2013) or distributed on sheared 'channel material'.

\subsubsection{Plate interface thickness}

Our compilation outlines that most units are thin slices $<\sim 300$ $500 \mathrm{~m}$ (Fig. 8a; Fig. 9e-h), similar yet somewhat thicker than those reported by Kimura and Ludden ( $200 \mathrm{~m}$; 1995). The thickest natural examples $(\sim 2-4 \mathrm{~km})$ are thinner than present-day examples inferred by geophysics ( $\sim-10 \mathrm{~km}$; Section 5.3). The contrast with Kimura and Ludden (1995) may come from the greater diversity of examples considered here and/or from the fact that packages more strongly metamorphosed may be more difficult to subdivide, each tectonic slice being potentially composed of many smaller, unrecognized imbricate structures developed during burial, such as those disrupting the ocean plate stratigraphy (Franciscan complex: Wakabayashi, 2015, 2017).

This average thickness thus scales with that of typical OPS sedimentary sequences (e.g., $0.5-1 \mathrm{~km}$ for sediments; Cliff et al., 2004) and places a lower bound (since some tectonic thinning may be involved) on the average volume 'capacity' of the plate interface. No particular depth-time-volume recovery systematics is apparent however, apart from one associated with cooling (Fig. 9g: warm fragments are commonly thin; metamorphic soles, however, have probably been thinned by a factor of $~ 5$; Soret et al., 2017a,b).

Fig. 12a provides a tentative picture of what the plate interface might look like. Irrespective of its 'average' value, plate interface thickness must vary at least during episodes of down-stepping and partial migration of rocks/units (Fig. 12a), to allow for the existence and accumulation of km-thick slices (deep examples: Tianshan: Bayet et al., 2018; W. Alps: Angiboust et al., 2009).

Since the width of active plate interface deformation is unlikely to be larger than the average thickness of the units stripped from the slab (Fig. $12 \mathrm{a}$; i.e., distributed deformation on $\mathrm{a} \geq \mathrm{km}$-scale shear zone would make additional strain localization across the hm-scale, in the slab, unlikely), we suggest that the regular plate interface thickness (i.e., when there is no detachment) is less than $\sim 300 \mathrm{~m}$.

This upper bound is consistent with estimates obtained for shallow depths (from $\sim 2$ to $15 \mathrm{~km}$, i.e. down to $\sim 250^{\circ}-300{ }^{\circ} \mathrm{C}$; Rowe et al., 2013 ) by studying strain localization at the $\mathrm{m}$ - to hm-scale. These authors suggested cumulative displacement on a 100-350-m-thick multistrand fault system (Fig. 12b; for shallow portions: e.g., Contreras-Reyes et al., 2017) sufficiently weak that gradual growth (at the expense of the oceanic plate) is 'discouraged'. Whether only some or all of the studied planes were active coevally is unclear, however, so that the extent of localization at a given time is uncertain.

\subsubsection{Coupled thickness}

The concept of 'coupled thickness' of the subduction zone, taken as the width across which strain is effectively distributed (Table1; Fig. $12 \mathrm{a}$ ), is probably more relevant here. During periods (and in areas) of strong mechanical coupling, this coupled thickness (always $\geq$ plate interface thickness) will comprise part of the upper plate (mantle wedge), the plate interface (i.e., potentially the roof and basal décollement and channel material) and any décollement horizon within the slab (e.g., at the contact between basalts and sheeted dykes; Fig. 12a).

Widening of the strain zone will result in more faults/shear bands with lower strain rates, which in turn may control which deformation mechanism is preferentially activated (e.g., diffusion versus dislocation creep; see Section 6.4). Strain rates are thus likely to drop below $\sim 10^{-11} \mathrm{~s}^{-1}$ (i.e., accomodation of $3 \mathrm{~cm} / \mathrm{yr}$ of slip on a $100 \mathrm{~m}$ wide plate interface, as in the downdip end of Fig. 12a), perhaps down to exhumation values, which are 1-2 orders of magnitude lower $\left(\sim 10^{-13} \mathrm{~s}^{-1}\right.$, for $\mathrm{mm} / \mathrm{yr}$ displacements on the hm-km scale). Whether or not exhumation will ensue will depend on density and viscosity ratios on both sides of the tectonic slice/mélange (Fig. 12a; exhumation number of Raimbourg et al., 2007) and deformation mechanisms once within the plate interface (Fig. 2b; e.g., Platt, 1993; Jolivet et al., 2003; Laurent et al., 2016; Soldner et al., 2017). Intuitively, once detachment is effective, specific boundary conditions need to be maintained long enough to allow for the exhumation of this transiently "channel material', which otherwise will get underplated or dragged down.

The concept of coupled thickness allows depicting the evolution of mechanical coupling through time (Fig. 12c) in a way that complements the evolution shown in Fig. 10. During subduction initiation and formation of HT soles the coupling thickness is maximum ( several km) across a wide depth interval ( $10 \mathrm{~km}$; Fig. 12c; see also Fig. 5a,b). Upon cooling, the coupled thickness decreases and changes location, moving both deeper for HT eclogites and shallower for LT soles (both form in first approximation coevally; Fig. 12c). From then on, coupled thickness is equivalent to plate interface thickness for most of the subduction history except during 'accidents' (Fig. 12c). It is thinner when shallow portions of the slab are recovered (e.g., S or SB types) than when crustal/lithospheric-scale fragments are (SBU type).

This evolution can be compared to effective short-term (only?) mechanical coupling along an active subduction zone (Fig. 12d). Owing to the scarcity of rocks recovered, effective coupling must generally be below the coupling threshold leading to detachment (vertical dashed line in Fig. 12d). The rock record (Fig. 8; Table2) indicates that chances of overcoming this critical threshold are greater at $\sim 30 \mathrm{~km}, 50 \mathrm{~km}$ and $70-80 \mathrm{~km}$ (dotted line and histogram in Fig. 12d), which points to the role of depth variations of coupled/decoupled transitions for the first and third cases.

\subsection{Mechanical coupling and strain (de)localization processes}

Increased mechanical coupling leading to effective rock detachment and recovery could in principle result from subduction of geometric obstacles (e.g., seamounts, asperities, rugosities; Wang and Bilek, 2011; Shillington et al., 2015; Bassett and Watts, 2015; Ruh et al., 2016; van Rijsingen et al., 2018), changes in regional slab dynamics/kinematics, or fluctuations in mineral reactions and fluid liberation (i.e., major changes in incoming rock types/lithologies). Seafloor obstacles, however, represent $\sim 17 \%$ of the total length of modern subduction systems (Vannucchi et al., 2016), much more than the fraction of rocks recovered in any fossil subduction system (see above), and are thus far from being systematically effective. Peaks of recovery may be controlled by regional-scale rearrangements of slab dynamics (e.g., slab convergence: Monié and Agard, 2009; Fig. 4a; slab roll-back: Brun and Faccenna, 2008; slab windows: McCrory et al., 2009; slab interference: Uchida et al., 2009), global changes in subduction flux and crustal accretion (Crameri et al., 2018, their Fig. 8c; Hounslow et al., 2018), or the Wilson cycle and/or mantle plumes (Vaughan and Scarrow, 2003; Dumitru et al., 2010; Kusky et al., 2013; van Hinsbergen et al., 2011), but quantification is yet to come.

Whatever the exact trigger, the possibility of detaching slab fragments (Fig. 3d) will depend on (i)how bulk/effective rheologies control mechanical coupling and (ii) which deformation mechanisms are activated during strain localization in weaker horizons and subsequent slicing.

Lubrication of the plate interface (particularly of the roof décollement), whether through weak hydrous phyllosilicates or pore fluids, is certainly essential. Progressive changes along the plate interface (Kitamura and Kimura, 2012) are indeed thought to be dominantly governed by dissolution-precipitation creep processes requiring only low effective stresses (Stöckhert, 2002; Wakabayashi, 2015; 

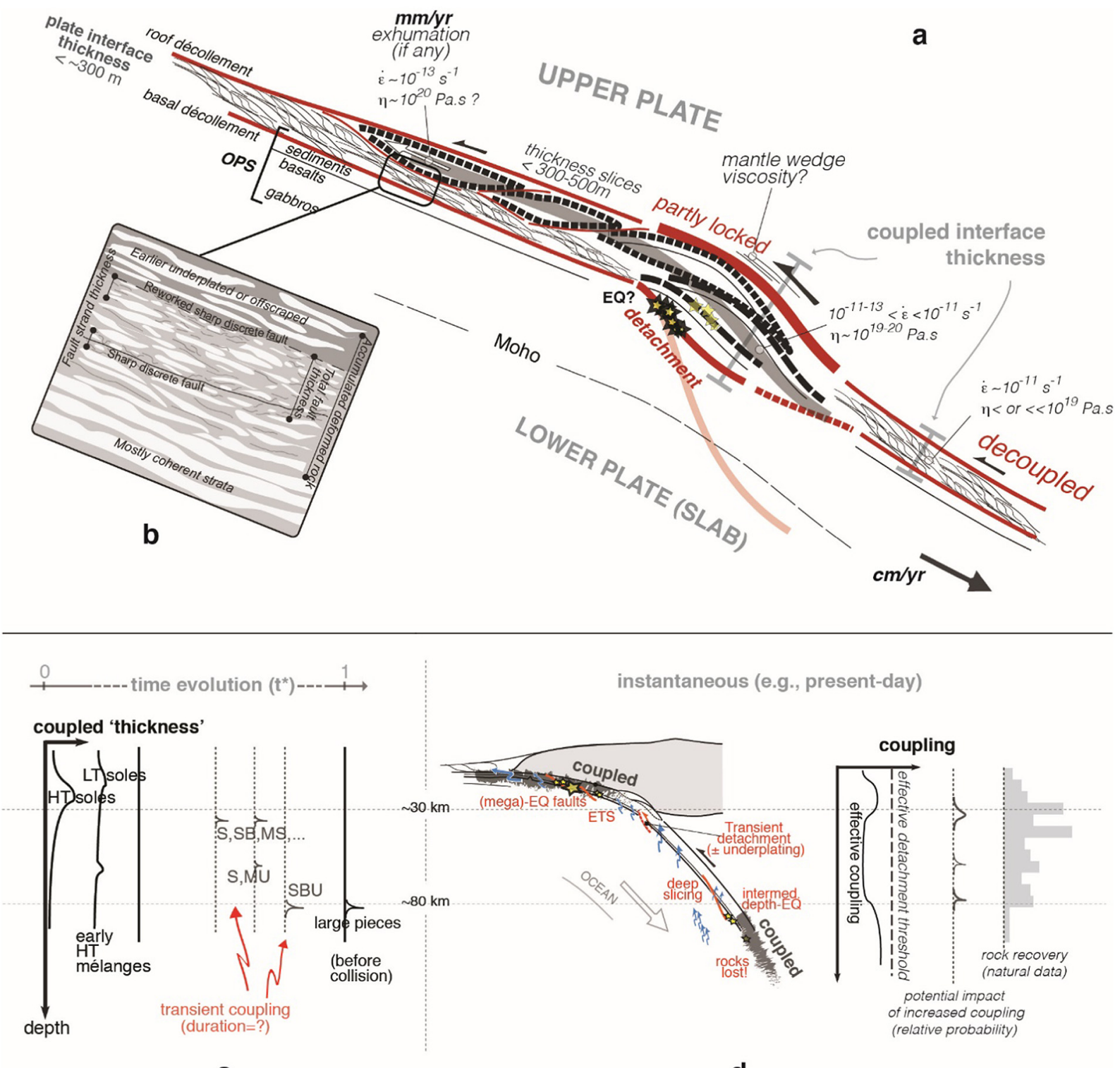

instantaneous (e.g., present-day)

C

d

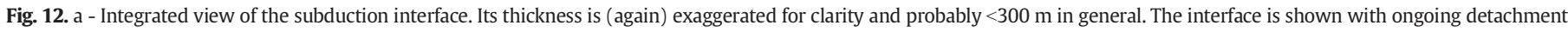

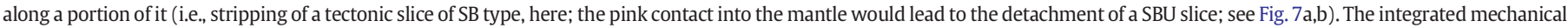

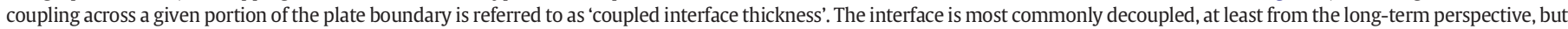

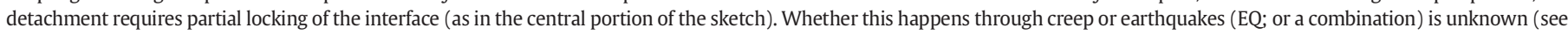

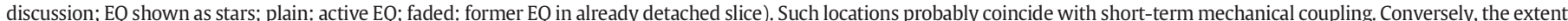

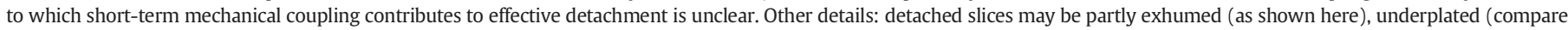

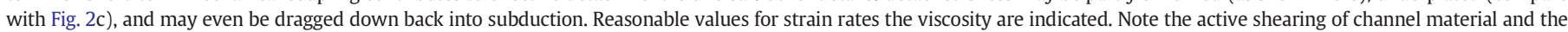

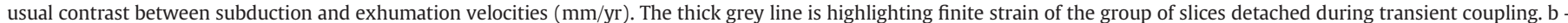

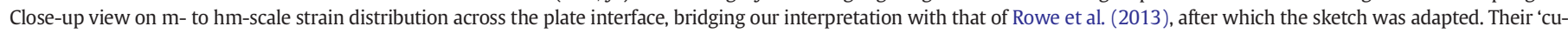

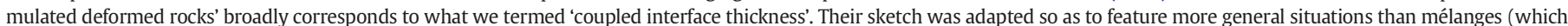

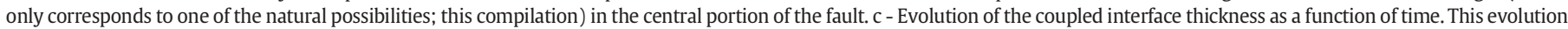

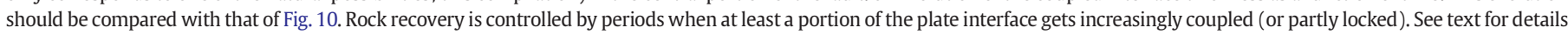

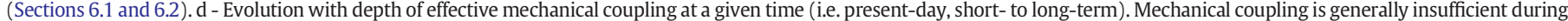

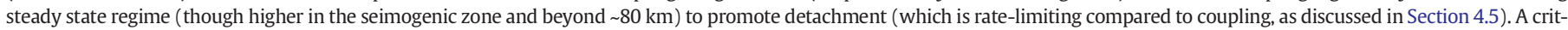

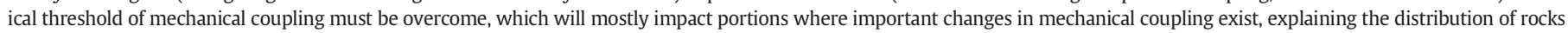
recovered (grey column to the right).

Wassmann and Stoeckhert, 2013). Kimura and Ludden (1995) argued that sealing by the 'precipitation of pore-filling and vesicle filling minerals, such as smectites and carbonates' creates a 100-150 m thick upper crust cap and controls the thickness of recovered tectonic slices. Similar permeability changes have been invoked in the context of ETS, e.g., sealing by the positive volume change of serpentinization, upward fluid transfer and down temperature silica deposition (Fig. 2c; Fisher and Brantley, 2014; Audet and Bürgmann, 2014; Gao and Wang,
2017) or deeper down (Bebout and Penniston-Dorland, 2016; Faccenda, 2014). The mechanical behavior of matrix mineral or mineral mixtures (Faulkner et al., 2010; Penniston-Dorland et al., 2018; Rowe et al., 2013), particularly in mélanges (Grigull et al., 2012), or the rheological evolution of sediments (which may control accretion/underplating: e.g. Kitamura and Kimura, 2012; Raimbourg et al., 2014; Vannucchi et al., 2017), may also contribute to strain hardening/weakening. Flow laws incorporating dissolution-precipitation and dislocation creep 
a

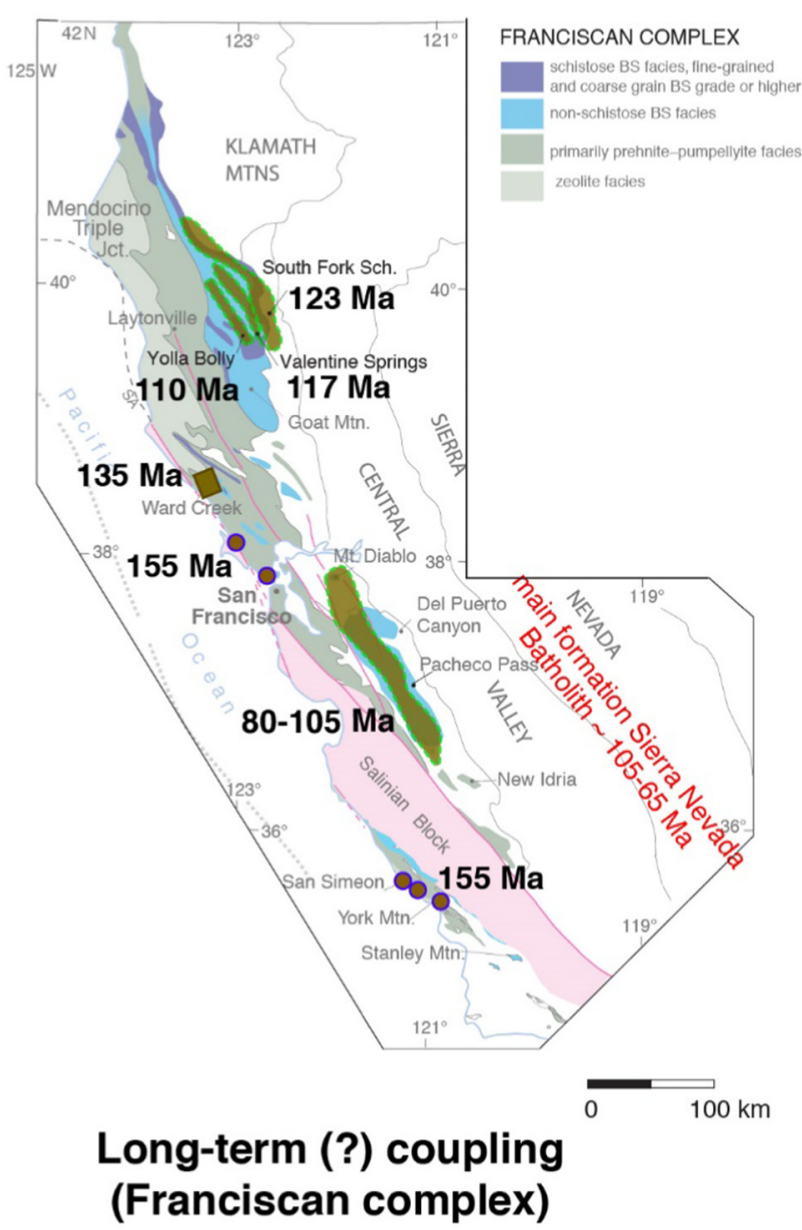

b

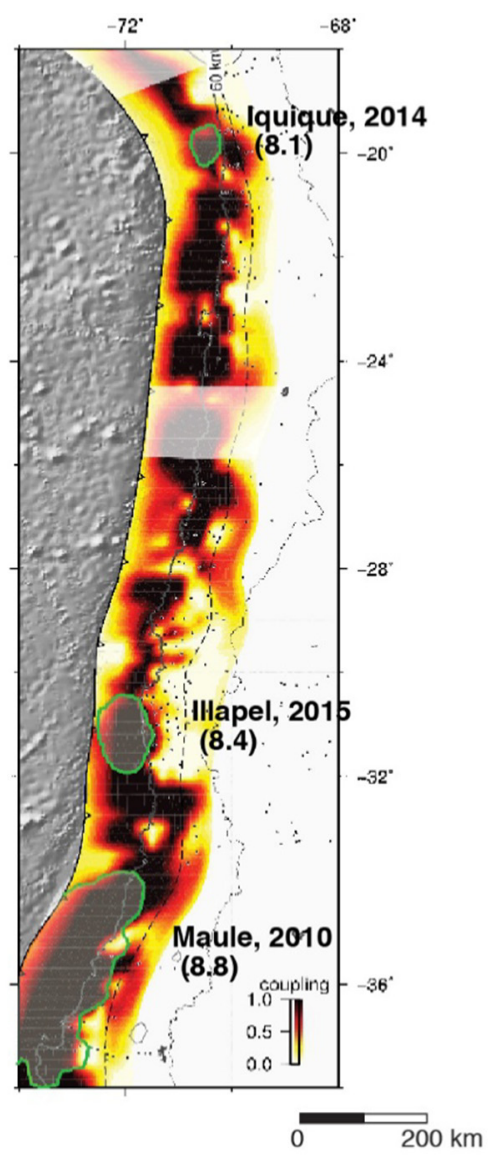

Short-term (?) coupling (Chilean subduction)

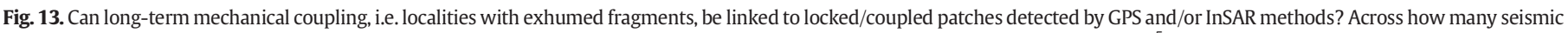

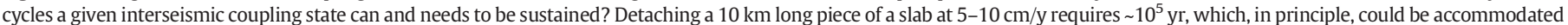

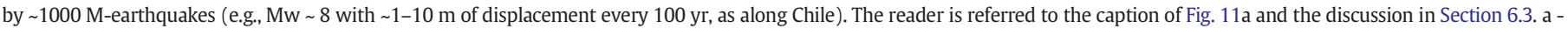

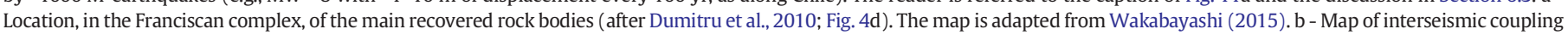
in the central part of Chile (Métois et al., 2016).

(Gratier et al., 2013; Wheeler, 1992) and mixing laws for polymineralic assemblages (i.e., rocks; Huet et al., 2014) are therefore required but yet unknown.

We propose that changes in mechanical coupling impact the depth and/or strength contrast of the coupled/decoupled transitions (Figs.3c and $12 \mathrm{~d}$ ), thereby explaining preferential exhumation around $30 \mathrm{~km}$ and $80 \mathrm{~km}$ :

- Near $30 \mathrm{~km}$ depth (i.e., the downdip limit of the seismogenic zone), mechanical coupling impacts deformation mechanisms fluctuating from frictional (potentially velocity weakening) to viscous flow (velocity strengthening), e.g., from plastic yielding on phyllosilicates to pressure-solution controlled deformation (Stöckhert, 2002; Fagereng et al., 2011; Vannucchi et al., 2009, 2012; Fagereng and den Hartog, 2017). Such switches in the brittle-ductile regime are commonly envisioned (Bachmann et al., 2009; Behr et al., 2018; Hayman and Lavier, 2014; Webber et al., 2018) as a result of fluctuations in near-lithostatic fluid pressure (Angiboust et al., 2015; Gao and Wang, 2017; Wallace et al., 2012 and references therein).

- Near $80 \mathrm{~km}$ depth, where serpentine may destabilize. Its distribution and mechanical behavior near the plate interface (i.e., within the first $\mathrm{km}$ ) are unknown (e.g., Bloch et al., 2014), with only estimates of bulk mantle wedge serpentinization (e.g., Abers et al., 2017: $<20$ $30 \%$ for most subduction zones, and only significant in warm ones where ETS are reported). A layered mantle wedge is in fact suspected down to $\sim 100 \mathrm{~km}$ from numerical modelling to best explain postseismic data (e.g., Freed et al., 2017). Any increase in strain rate, via increased shear heating and/or mechanical abrasion of the serpentinite horizon (Fig. 6a,c; Section 4.3), will tend to restrict serpentinization, leading to hardening of the roof décollement. This could tentatively explain rock recovery associated with an increase in convergence velocities (e.g., for the Neotethys at $95 \mathrm{Ma}$ Section 4.1; Monié and Agard, 2009).

The origin of a third peak of recovery, near 55-60 km (1.7-1.8 GPa, Fig. 8d; Groppo et al., 2016; and/or the gap until 2.3 GPa) is more enigmatic. These examples might represent cases for which recoupling depths are shallower than $80 \mathrm{~km}$ depth (i.e., warm gradients; Fig. $11 \mathrm{~b}$ ). Dehydration reactions (particularly those with $\Delta \mathrm{V}>0$, which may be velocity-weakening) may provide an alternative explanation, since fluids released by the breakdown of chlorite (to garnet, liberating $\sim 12$ wt\% $\mathrm{H}_{2} \mathrm{O}$ : Angiboust and Agard, 2010), lawsonite (to epidote: 6.5 wt\% $\mathrm{H}_{2} \mathrm{O}$ : Schmidt and Poli, 1998, 2014; Vitale-Brovarone and Agard, 2013) or carpholite (to chloritoid: $4.5 \mathrm{wt} \% \mathrm{H}_{2} \mathrm{O}$; Agard et al., 2001) will impact strain localization in this specific depth range in metabasites (first two reactions) and metasediments (last two reactions). 


\subsection{Bridging long and short time scales}

Mechanical coupling being rate-limiting for rock recovery (Section 4.5), the question arises as to how long an increased interseismic coupling state needs to be sustained (see Kaneko et al., 2010; Kinoshita and Tobin, 2013; Wakabayashi and Rowe, 2015) to detach slab fragments, and whether this will happen mostly through creep (i.e., macroscopically ductile formation, whether mylonitic or cataclastic; Wassmann and Stoeckhert, 2013; Fagereng and Sibson, 2010) or earthquakes (whether regular or slow-slip; Ide et al., 2007; Peng and Gomberg, 2010). Detaching a $10 \mathrm{~km}$ long slab fragment (e.g., a small seamount; Singh et al., 2012; Toda et al., 2008) at 5-10 cm/yr requires $\sim 10^{5} \mathrm{yr}$, which could be accommodated by $\sim 1000$ mega-earthquakes (considering one Mw 8 with $\sim 1-10 \mathrm{~m}$ of displacement every $100 \mathrm{yr}$, as along Chile). One can therefore tentatively link long-term mechanical coupling inferred from areas where rocks are recovered (Fig. 13a) to locking/coupling patches inferred from GPS images (Fig. 13b; e.g., for Chile; Metois et al., 2012, 2016; Moreno et al., 2011; Ecuador: Nocquet et al., 2017). Song and Simons (2003) have indeed suggested, based on trench-parallel gravity variations, that the seismogenic behavior within a given subduction zone is stationary and linked to geological structures over time scales up to at least 1 Myr (see also Uchida et al., 2009).

\subsubsection{Stability of mechanical coupling through time}

High-resolution geophysical imaging recently revealed the existence of several high-Vp patches along the plate interface, advocating for a strong upper plate and/or a relatively dry subduction channel and a locked and potentially loaded megathrust fault (Paulatto et al., 2017; stars on Fig. 8d). The discovery of aftershocks in the deep wake of megathrust planes, down to 50-60 km (Frank et al., 2015) may indicate that seismic fault planes extend downdip into major tectonic structures (as featured by stars on Fig. 12a). At shallower depths, slow-slip events were taken as evidence for active underplating (Kimura et al., 2010; see also Tsuji et al., 2017). Active underplating is inferred from large EQ and uplift near the Yakutat plateau subduction in the area of the 1964 Great Alaskan rupture (Haeussler et al., 2015).

Whether or not these features are stable through time is yet unknown (e.g., Melnick et al., 2017). Geological information bridging the seismic cycle with a fraction of $\mathrm{Myr}$ (e.g., $10^{2}$ to $10^{5} \mathrm{yr}$ ) may come from systematic investigation of terrace uplift (e.g., SAmerica: Bookhagen et al., 2006; Saillard et al., 2009) and long-term trends in mechanical coupling (e.g., across the Andes: Oncken et al., 2006). Geodynamic modelling (e.g., impact of plateau and fore-arc uplift: Vogt and Gerya, 2014a; Sobolev and Muldashev, 2017; Govers et al., 2018) may test which conditions and rheologies, in the context of steady-statelong-term coupling with recurrent seismicity, trigger detachment instabilities on the $10^{5}$ to $10^{6} \mathrm{yr}$ scale.

\subsubsection{Creeping or seismic?}

Reports of EQ are still relatively rare in metamorphic rocks due to overprinting, particularly on detachment shear zones reworked multiple times (Fig. 12a; e.g., basal versus lower shear zone in Angiboust et al., 2011). Some intermediate-depthEQ were nevertheless documented (Zambia: John and Schenk, 2006; Corsica: Andersen and Austrheim, 2006; Magott et al., 2016) and can be assigned to portions of the slab (W. Alps: Angiboust et al., 2012a,b; Scambelluri et al., 2017). Strain localization has also been shown to involve significant fluid migration (e.g. Angiboust et al., 2014a,b), which is in turn suspected to operate on seismic cycle timescales: vein filling (John et al., 2012; Taetz et al., 2018), garnet growth $\leq 10^{4-5} \mathrm{yr}$ (Dragovic et al., 2012) and even flash garnet or clinopyroxene growth ( $<1$ yr; Deseta et al., 2014; Menant et al., 2018) indeed match fluid migration on seismic cycle time-scales (Audet et al., 2009; Frank et al., 2015).
Some correlation between the depths of intra-slabEQ and the distribution of rock remnants (Fig. 8d) hints to the possibility of linking nests of EQ to detachment in active subduction zones. This could be further tested by scrutinizing present-day subduction zones with dense seismic networks in the most favorable areas (e.g., Puysegur; Hayes et al., 2009; Choi et al., 2017). However, if displacement is controlled by features such as the numerous $10 \mathrm{~cm}$ long veins found in rocks, which have been argued to accommodate plate interface movements (Fagereng et al., 2011) or invoked in some fracture and viscous flow models (Hayman and Lavier, 2014), their formation would require negative magnitude EQ lasting a fraction of seconds, thus pointing to creep rather than detectable $\mathrm{EQ}$.

\section{Conclusions}

Based on critical observations and an exhaustive compilation of worldwide subducted oceanic rocks, the present study demonstrates how long-term mechanical coupling exerts a key control on detachment from the slab and potential rock recovery from subduction zones. This calls for changing the current paradigm in subduction zone tectonics, from wondering how (deep) rocks are exhumed to how they get detached and what this tells us about active processes:

- The critical assessment of rock T/P characteristics indicates that these fragments track subduction interface dynamics down to $\sim 2.8 \mathrm{GPa}$ and can be used as reliable natural probes.

- Rock clusters can be identified at depths of $30 \mathrm{~km}$ and $80 \mathrm{~km}$, and possibly 55-60 km, with some differences between rock types. Outstanding features are the broad cluster at $25-35 \mathrm{~km}$ and the sharp drop in recovery beyond $80 \mathrm{~km}$.

- There is a first-order impact of subduction cooling on rock recovery, which is interpreted as reflecting a systematic trend from strong to weak mechanical coupling - after which ( $>$ 5 Myr) subduction is lubricated and mostly inhibits rock recovery.

- Mechanical coupling, rather than tectonic slicing, is likely rate-limiting and controls the occasional detachment from the slab. Later exhumation (providing favorable density and viscosity conditions) likely shortly ensues after detachment.

- Mechanical coupling depends on mantle wedge rheology, viscosity contrasts and initial structure (e.g., existence of décollement horizons, heterogeneous lithosphere, extent of hydration, asperities, etc.) but also on boundary conditions (convergence rates, kinematics). Strain localization processes involve creep (notably grain size sensitive deformation mechanisms such as dissolution-precipitation) and possibly brittle fractures and EQ, even at intermediate depths.

- We provide estimates for regular plate interface thickness (<300 m; i. e. where/when there is no detachment) and effective viscosity required for rock recovery (i.e., $\sim 10^{19-20} \mathrm{~Pa} \cdot \mathrm{s}$, inferred from the evolution from $10^{20-21}$ to $\sim 10^{19-20} \mathrm{~Pa} \cdot \mathrm{s}$ during early subduction).

- Plate interface geometry will change during episodes of strong mechanical coupling: we herein use the concept of 'coupled thickness' to capture subduction interface dynamics and link long-term mechanical coupling with present-day, short-term mechanical coupling inferred from geophysical data.

- Although most present-day subduction zone segments (both along strike and downdip) are likely below the detachment threshold, we propose that transitional zones between coupled and decoupled areas, notably at $30 \mathrm{~km}$ and $80 \mathrm{~km}$ depth, are most favorable for detachment and predict differences between warm and cold subduction settings.

Our study suggests that bridging long- to short-term processes (and vice versa) should be possible. Future progress in our understanding of subduction zones will require better relocation (both for rocks and EQ), 
radiochronometers able to track short-lived processes on the order of $10^{2}-10^{5} \mathrm{yr}$ and dedicated thermomechanical modelling with adequate rheologies/viscosities.

\section{Acknowledgements}

This work was partly funded by the ZIP project (REA grant agreement no. 604713 (ZIP "Zooming In between Plates") from the People Programme (Marie Curie Actions) of the European Union's Seventh Framework ProgrammeFP7/2007-2013), and benefited from discussions with the many ZIP scientists involved. Special thanks are due to Michael Bostock, Onno Oncken, John Wakabayashi, Gray Bebout and Stéphane Guillot. The manuscript benefited from the useful suggestions of Antonio Garcia-Casco, Federico Rossetti and the Editor, Marco Scambelluri. P.A. acknowledges the support of a grant from Institut Universitaire de France.

\section{References}

Abbott, R.N., Draper, G., 2010. Comments on "Corundum-bearing garnet peridotite from northern Dominican Republic: a metamorphic product of an arc cumulate in the Caribbean subduction zone," by Hattori et al. [Lithos 114 (2010) 437-450]. Lithos 117, 322-326. https://doi.org/10.1016/j.lithos.2010.03.011.

Abd El-Naby, H., Frisch, W., Hegner, E., 2000. Evolution of the Pan-African Wadi Haimur metamorphic sole, Eastern Desert, Egypt. J. Metamorph. Geol. 18, 639-651. https:/ doi.org/10.1046/j.1525-1314.2000.00286.x.

Abers, G.A., 2005. Seismic low-velocity layer at the top of subducting slabs: observations, predictions, and systematics. Phys. Earth Planet. Interiors 149, 7-29. https://doi.org/ 10.1016/j.pepi.2004.10.002.

Abers, G.A., van Keken, P.E., Hacker, B.R., 2017. The cold and relatively dry nature of mantle forearcs in subduction zones. Nat. Geosci. 10, 333-337. https://doi.org/10.1038/ ngeo2922.

Abers, G.A., MacKenzie, L.S., Rondenay, S., Zhang, Z., Wech, A.G., Creager, K.C., 2009. Imaging the source region of Cascadia tremor and intermediate-depth earthquakes. Geology 37, 1119-1122. https://doi.org/10.1130/G30143A.1.

Abers, G.A., Nakajima, J., van Keken, P.E., Kita, S., Hacker, B.R., 2013. Thermal-petrological controls on the location of earthquakes within subducting plates. Earth Planet. Sci. Lett. 369, 178-187. https://doi.org/10.1016/j.epsl.2013.03.022.

Abers, G.A., van Keken, P.E., Kneller, E.A., Ferris, A., Stachnik, J.C., 2006. The thermal structure of subduction zones constrained by seismic imaging: implications for slab dehydration and wedge flow. Earth Planet. Sci. Lett. 241, 387-397. https://doi.org/ 10.1016/j.epsl.2005.11.055.

Agard, P., Jolivet, L., Goffe, B., 2001. Tectonometamorphic evolution of the Schistes Lustre's complex: implications for the exhumation of HP and UHP rocks in the western Alps. Bull. Soc. Geol. Fr. 172, 617-636. https://doi.org/10.2113/172.5.617.

Agard, P., Jolivet, L., Vrielynck, B., Burov, E., Monié, P., 2007. Plate acceleration: the obduction trigger? Earth Planet. Sci. Lett. 258, 428-441. https://doi.org/10.1016/j. epsl.2007.04.002.

Agard, P., Monié, P., Gerber, W., Omrani, J., Molinaro, M., Meyer, B., Labrousse, L., Vrielynck, B., Jolivet, L., Yamato, P., 2006. Transient, synobduction exhumation of Zagros blueschists inferred from P-T, deformation, time, and kinematic constraints: Implications for Neotethyan wedge dynamics. J. Geophys. Res.-Solid Earth 111, B11401. https://doi.org/10.1029/2005JB004103.

Agard, P., Monié, P., Jolivet, L., Goffe, B., 2002. Exhumation of the Schistes Lustres complex: in situ laser probe $\mathrm{Ar}-40 / \mathrm{Ar}-39$ constraints and implications for the Western Alps. J. Metamorph. Geol. 20, 599-618. https://doi.org/10.1046/j.1525-1314.2002.00391.x.

Agard, P., Omrani, J., Jolivet, L., Mouthereau, F., 2005. Convergence history across Zagros (Iran): constraints from collisional and earlier deformation. Int. J. Earth Sci. (Geol. Rundsch.) 94, 401-419. https://doi.org/10.1007/s00531-005-0481-4

Agard, P., Omrani, J., Jolivet, L., Whitechurch, H., Vrielynck, B., Spakman, W., Monié, P. Meyer, B., Wortel, R., 2011. Zagros orogeny: a subduction-dominated process. Geol. Mag. 148, 692-725. https://doi.org/10.1017/S001675681100046X.

Agard, P., Yamato, P., Jolivet, L., Burov, E., 2009. Exhumation of oceanic blueschists and eclogites in subduction zones: timing and mechanisms. Earth Sci. Rev. 92, 53-79. https://doi.org/10.1016/j.earscirev.2008.11.002.

Agard, P., Yamato, P., Soret, M., Prigent, C., Guillot, S., Plunder, A., Dubacq, B., Chauvet, A. Monié, P., 2016. Plate interface rheological switches during subduction infancy: control on slab penetration and metamorphic sole formation. Earth Planet. Sci. Lett. 451, 208-220. https://doi.org/10.1016/j.epsl.2016.06.054.

Ague, J.J., 2017. Element mobility during regional metamorphism in crustal and subduction zone environments with a focus on the rare earth elements (REE). Am. Mineral. 102, 1796-1821. https://doi.org/10.2138/am-2017-6130.

Anczkiewicz, R., Burg, J.P., Villa, I.M., Meier, M., 2000. Late Cretaceous blueschist metamorphism in the Indus Suture Zone, Shangla region, Pakistan Himalaya. Tectonophysics 324, 111-134. https://doi.org/10.1016/S0040-1951(00)00110-4

Anczkiewicz, R., Platt, J.P., Thirlwall, M.F., Wakabayashi, J., 2004. Franciscan subduction off to a slow start: evidence from high-precisionLu-Hf garnet ages on high grade-blocks. Earth Planet. Sci. Lett. 225, 147-161. https://doi.org/10.1016/j.espl.2004.06.003.

Andersen, T.B., Austrheim, H., 2006. Fossil earthquakes recorded by pseudotachylytes in mantle peridotite from the Alpine subduction complex of Corsica. Earth Planet. Sci. Lett. 242, 58-72. https://doi.org/10.1016/j.epsl.2005.11.058.
Angiboust, S., Agard, P., 2010. Initial water budget the key to detaching large volumes of eclogitized oceanic crust along the subduction channel? Lithos 120, 453-474. https:// doi.org/10.1016/j.lithos.2010.09.007.

Angiboust, S., Agard, P., De Hoog, J.C.M., Omrani, J., Plunder, A., 2013. Insights on deep, accretionary subduction processes from the Sistan ophiolitic "melange" (Eastern Iran). Lithos 156, 139-158. https://doi.org/10.1016/j.lithos.2012.11.007.

Angiboust, S., Agard, P., Glodny, J., Omrani, J., Oncken, O., 2016. Zagros blueschists: episodic underplating and long-lived cooling of a subduction zone. Earth Planet. Sci. Lett. 443, 48-58. https://doi.org/10.1016/j.epsl.2016.03.017.

Angiboust, S., Agard, P., Jolivet, L., Beyssac, O., 2009. The Zermatt-Saas ophiolite: the largest (60-km wide) and deepest (c. 70-80 km) continuous slice of oceanic lithosphere detached from a subduction zone? Terr. Nova 21, 171-180. https://doi.org/10.1111/ j.1365-3121.2009.00870.x.

Angiboust, S., Agard, P., Raimbourg, H., Yamato, P., Huet, B., 2011. Subduction interface processes recorded by eclogite-facies shear zones (Monviso, W. Alps). Lithos 127, 222-238. https://doi.org/10.1016/j.lithos.2011.09.004.

Angiboust, S., Agard, P., Yamato, P., Raimbourg, H., 2012a. Eclogite breccias in a subducted ophiolite: a record of intermediate-depth earthquakes? Geology 40, 707-710. https://doi.org/10.1130/G32925.1.

Angiboust, S., Glodny, J., Oncken, O., Chopin, C., 2014a. In search of transient subduction interfaces in the Dent Blanche-Sesia Tectonic System (W. Alps). Lithos 205, 298-321. https://doi.org/10.1016/j.lithos.2014.07.001.

Angiboust, S., Hyppolito, T., Glodny, J., Cambeses, A., Garcia-Casco, A., Calderon, M., Juliani, C., 2017. Hot subduction in the middle Jurassic and partial melting of oceanic crust in Chilean Patagonia. Gondwana Res. 42, 104-125. https://doi.org/10.1016/j. gr.2016.10.007.

Angiboust, S., Cambeses, A., Hyppolito, T., Glodny, J., Monié, P., Calderon, M., Juliani, C., 2018. A 100-m.y.-long window onto mass-flow processes in the Patagonian Mesozoic subduction zone (Diego de Almagro Island, Chile). Geol. Soc. Am. Bull. https://doi.org/ 10.1130/B31891.

Angiboust, S., Kirsch, J., Oncken, O., Glodny, J., Monié, P., Rybacki, E., 2015. Probing the transition between seismically coupled and decoupled segments along an ancient subduction interface. Geochem. Geophys. Geosyst. 16, 1905-1922. https://doi.org/ 10.1002/2015GC005776

Angiboust, S., Langdon, R., Agard, P., Waters, D., Chopin, C., 2012b. Eclogitization of theMonviso ophiolite (W. Alps) and implications on subduction dynamics. J. Metamorph. Geol. 30, 37-61. https://doi.org/10.1111/j.1525-1314.2011. 00951.x.

Angiboust, S., Pettke, T., De Hoog, J.C.M., Caron, B., Oncken, O., 2014b. Channelized fluid flow and eclogite-facies Metasomatism along the Subduction Shear Zone. J. Petrol. 55, 883-916. https://doi.org/10.1093/petrology/egu010.

Angiboust, S., Wolf, S., Burov, E., Agard, P., Yamato, P., 2012c. Effect of fluid circulation on subduction interface tectonic processes: insights from thermo-mechanical numerical modelling. Earth Planet. Sci. Lett. 357, 238-248. https://doi.org/10.1016/j. epsl.2012.09.012

Ao, A., Bhowmik, S.K., 2014. Cold subduction of the Neotethys: the metamorphic record from finely banded lawsonite and epidote blueschists and associated metabasalts of the Nagaland Ophiolite complex, India. J. Metamorph. Geol. 32, 829-860. https:// doi.org/10.1111/jmg.12096.

Aoki, K., Itaya, T., Shibuya, T., Masago, H., Kon, Y., Terabayashi, M., Kaneko, Y., Kawai, T., Maruyama, S., 2008. The youngest blueschist belt in SWJapan: implication for the exhumation of the cretaceous Sambagawa high-P/T metamorphic belt. J. Metamorph. Geol. 26, 583-602. https://doi.org/10.1111/j.1525-1314.2008.00777.x.

Aoki, K., Kitajima, K., Masago, H., Nishizawa, M., Terabayashi, M., Omori, S., Yokoyama, T., Takahata, N., Sano, Y., Maruyama, S., 2009. Metamorphic P-T-time history of the Sambagawa belt in Central Shikoku, Japan and implications for retrograde metamorphism during exhumation. Lithos 113, 393-407. https://doi.org/10.1016/j. lithos.2009.04.033.

Aoya, M., 2002. Structural position of the Seba eclogite unit in the Sambagawa Belt: supporting evidence for an eclogite nappe. Island Arc 11, 91-110. https://doi.org/ 10.1046/j.1440-1738.2002.00359.x.

Aoya, M., Endo, S., Mizukami, T., Wallis, S.R., 2013. Paleo-mantle wedge preserved in the Sambagawa high-pressure metamorphic belt and the thickness of forearc continental crust. Geology 41, 451-454. https://doi.org/10.1130/G33834.1.

Aoya, M., Mizukami, T., Uehara, S., Wallis, S.R., 2009. High-P metamorphism, pattern of induced flow in the mantle wedge, and the link with plutonism in paired metamorphic belts. Terra Nova 21, 67-73. https://doi.org/10.1111/j.1365-3121.2008.00860.x.

Aoya, M., Tsuboi, M., Wallis, S.R., 2006. Origin of eclogitic metagabbro mass in the Sambagawa belt: Geological and geochemical constraints. Lithos 89, 107-134. https://doi.org/10.1016/j.lithos.2005.10.001.

Aoya, M., Uehara, S., Matsumoto, M., Wallis, S.R., Enami, M., 2003. Subductionstagepressure-temperature path of eclogite from the Sambagawa belt: Prophetic record for oceanic-ridge subduction. Geology 31, 1045-1048. https://doi.org/10.1130/ G19927.1.

Audet, P., Bostock, M.G., Christensen, N.I., Peacock, S.M., 2009. Seismic evidence for overpressured subducted oceanic crust and megathrust fault sealing. Nature 457, 76.

Audet, P., Bürgmann, R., 2014. Possible control of subduction zone slow-earthquake periodicity by silica enrichment. Nature 510,389 .

Audet, P., Kim, Y., 2016. Teleseismic constraints on the geological environment of deep episodic slow earthquakes in subduction zone forearcs: a review. Tectonophysics $670,1-15$.

Aygul, M., Oberhaensli, R., 2017. Tectonic stacking of HP/LT metamorphic rocks in accretionary wedges and the role of shallowing slab-mantle decoupling. Tectonics 36 (36), 2332-2346. https://doi.org/10.1002/2017TC004689.

Bachmann, R., Oncken, O., Glodny, J., Seifert, W., Georgieva, V., Sudo, M., 2009. Exposed plate interface in the European Alps reveals fabric styles and gradients related to an 
ancient seismogenic coupling zone. J. Geophys. Res. Solid Earth, 114 https://doi.org/ 10.1029/2008JB005927.

Banno, S., Shibakusa, H., Enami, M., Wang, C.L., Ernst, W.G., 2000. Chemical fine structure of Franciscan jadeitic pyroxene from Ward Creek, Cazadero area, California. Am. Mineral. 85, 1795-1798.

Bassett, D., Watts, A.B., 2015. Gravity anomalies, crustal structure, and seismicity at subduction zones: 1 . Seafloor roughness and subducting relief. Geochem. Geophys. Geosyst. 16, 1508-1540. https://doi.org/10.1002/2014GC005684.

Bayet, L., John, T., Agard, P., Gao, J., Li, J.-L., 2018. Massive sediment accretion at $\sim 80 \mathrm{~km}$ depth along the subduction interface: evidence from the southern Chinese Tianshan. Geology 46, 495-498. https://doi.org/10.1130/G40201.1.

Bebout, G.E., 2007. Metamorphic chemical geodynamics of subduction zones. Earth Planet. Sci. Lett. 260, 373-393. https://doi.org/10.1016/j.epsl.2007.05.050.

Bebout, G.E., Penniston-Dorland, S.C., 2016. Fluid and mass transfer at subduction interfaces-the field metamorphic record. Lithos 240-243, 228-258. https://doi.org/ 10.1016/j.lithos.2015.10.007.

Behn, M.D., Kelemen, P.B., Hirth, G., Hacker, B.R., Massonne, H.-J., 2011. Diapirs as the source of the sediment signature in arc lavas. Nat. Geosci. 4, 641-646. https://doi. org/10.1038/ngeo1214.

Behr, W.M., Kotowski, A.J., Ashley, K.T., 2018. Dehydration-induced rheological heterogeneity and the deep tremor source in warm subduction zones. Geology https://doi.org 10.1130/G40105.1.

Behr, W.M., Becker, T.W., 2018. Sediment control on subduction plate speeds. Earth Planet. Sci. Lett. 502, 166-173.

Blanco-Quintero, I., Garcia-Casco, A., Rojas-Agramonte, Y., Rodriguez-Vega, A., Lazaro, C. Iturralde-Vinent, M.A., 2010a. Metamorphic evolution of subducted hot oceanic crust (la Corea Melange, Cuba). Am. J. Sci. 310, 889-915. https://doi.org/10.2475/ 11.2010 .01 .

Blanco-Quintero, I.F., Gerya, T.V., Garcia-Casco, A., Castro, A., 2011. Subduction of young oceanic plates: A numerical study with application to aborted thermal-chemical plumes. Geochem. Geophys. Geosyst. 12 (10).

Blanco-Quintero, I.F., Rojas-Agramonte, Y., Garcia-Casco, A., Kroener, A., Mertz, D.F. Lazaro, C., Blanco-Moreno, J., Renne, P.R., 2011. Timing of subduction and exhumation in a subduction channel: melts from La Corea Melange (eastern Cuba). Lithos 127, 86-100. https://doi.org/10.1016/j.lithos.2011.08.009.

Bloch, W., Kummerow, J., Salazar, P., Wigger, P., Shapiro, S.A., 2014. High-resolution image of the North Chilean subduction zone: seismicity, reflectivity and fluids. Geophys. J. Int. 197, 1744-1749. https://doi.org/10.1093/gji/ggu084.

Bonnet, G., Agard, P., Angiboust, S., Monié, P., Jentzer, M., Omrani, J., Whitechurch, H. Fournier, M., 2018. Tectonic slicing and mixing processes along the subduction interface: the Sistan example (Eastern Iran). Lithos 310-311, 269-287. https://doi.org/ 10.1016/j.lithos.2018.04.016.

Bookhagen, B., Echtler, H.P., Melnick, D., Strecker, M.R., Spencer, J.Q.G., 2006. Using uplifted Holocene beach berms for paleoseismic analysis on the Santa Maria Island, south-Central Chile. Geophys. Res. Lett. 33, L15302. https://doi.org/10.1029/ 2006GL026734.

Bosch, D., Gabriele, P., Lapierre, H., Malfere, J.L., Jaillard, E., 2002. Geodynamic significance of the Raspas Metamorphic complex (SW Ecuador): geochemical and isotopic constraints. Tectonophysics 345, 83-102. https://doi.org/10.1016/S0040-1951(01) 00207-4.

Bostock, M.G., 2013. The Moho in subduction zones. Tectonophysics 609, 547-557. https://doi.org/10.1016/j.tecto.2012.07.007.

Bostock, M.G., Hyndman, R.D., Rondenay, S., Peacock, S.M., 2002. An inverted continental Moho and serpentinization of the forearc mantle. Nature 417, 536-538. https://doi. org/10.1038/417536a.

Bousquet, R., Goffe, B., Vidal, O., Oberhansli, R., Patriat, M., 2002. The tectono-metamorphic history of the Valaisan domain from the Western to the Central Alps: new constraints on the evolution of the Alps. Geol. Soc. Am. Bull. 114, 207-225. https://doi. org/10.1130/0016-7606(2002)114<0207:TTMHOT>2.0.CO;2.

Bousquet, R., Oberhansli, R., Goffe, B., Jolivet, L., Vidal, O., 1998. High-pressure-low-temperature metamorphism and deformation in the Bundnerschiefer of the Engadine window: implications for the regional evolution of the eastern Central Alps. J. Metamorph. Geol. 16, 657-674. https://doi.org/10.1111/j.1525-1314.1998. 00161.x.

Brandon, M., Calderwood, A., 1990. High-pressure metamorphism and uplift of the olympic subduction complex. Geology 18, 1252-1255. https://doi.org/10.1130/0091-7613 (1990)018<1252:HPMAUO >2.3.CO;2.

Broecker, M., Rad, G.F., Burgess, R., Theunissen, S., Paderin, I., Rodionov, N., Salimi, Z., 2013. New age constraints for the geodynamic evolution of the Sistan Suture Zone, eastern Iran. Lithos 170, 17-34. https://doi.org/10.1016/j.lithos.2013.02.012.

Brown, M., Johnson, T., 2018. Secular change in metamorphism and the onset of global plate tectonics. Am. Mineral. 103, 181-196. https://doi.org/10.2138/am-2018-6166.

Brun, J.-P., Faccenna, C., 2008. Exhumation of high-pressure rocks driven by slab rollback. Earth Planet. Sci. Lett. 272, 1-7. https://doi.org/10.1016/j.epsl.2008.02.038.

Bucher, K., Fazis, Y., De Capitani, C., Grapes, R., 2005. Blueschists, eclogites, and decompression assemblages of the Zermatt-Saas ophiolite: High-pressure metamorphism of subducted Tethys lithosphere. Am. Mineral. 90, 821-835. https://doi.org/ 10.2138/am.2005.1718.

Calahorrano, A., Sallarès, V., Collot, J.-Y., Sage, F., Ranero, C.R., 2008. Nonlinear variations of the physical properties along the southern Ecuador subduction channel: results from depth-migrated seismic data. Earth Planet. Sci. Lett. 267, 453-467.

Calvert, A.J., 2004. Seismic reflection imaging of two megathrust shear zones in the northern Cascadia subduction zone. Nature 428, 163-167. https://doi.org/10.1038 nature02372.

Candan, O., Cetinkaplan, M., Oberhansli, R., Rimmele, G., Akal, C., 2005. Alpine high-P/lowT metamorphism of the Afyon Zone and implications for the metamorphic evolution of Western Anatolia, Turkey. Lithos 84, 102-124. https://doi.org/10.1016/j. lithos.2005.02.005

Cannao, E., Scambelluri, M., Agostini, S., Tonarini, S., Godard, M., 2016. Linking serpentinite geochemistry with tectonic evolution at the subduction plate-interface: the Voltri Massif case study (Ligurian Western Alps, Italy). Geochim. Cosmochim. Acta 190, 115-133. https://doi.org/10.1016/j.gca.2016.06.034.

Carson, C.J., Powell, R., Clarke, G.L., 1999. Calculated mineral equilibria for eclogites in $\mathrm{CaO}-\mathrm{Na} 2 \mathrm{O}-\mathrm{FeO}-\mathrm{MgO}-\mathrm{Al} 2 \mathrm{O} 3-\mathrm{SiO} 2-\mathrm{H} 2 \mathrm{O}$ : application to the Pouebo Terrane, Pam Peninsula, New Caledonia. J. Metamorph. Geol. 17, 9-24.

Casey, J.F., Dewey, J.F., 1984. Initiation of subduction zones along transform and accreting plate boundaries, triple-junction evolution, and forearc spreading centres-implications for ophiolitic geology and obduction. Geol. Soc. Lond., Spec. Publ. 13, 269-290. https://doi.org/10.1144/GSL.SP.1984.013.01.22.

Castelli, D., Rostagno, C., Lombardo, B., 2002. JD-QTZ-bearing metaplagiogranite from the Monviso meta-ophiolite (Western Alps). Ofioliti 27, 81-90.

Choi, H., Kim, S.-S., Dyment, J., Granot, R., Park, S.-H., Hong, J.K., 2017. The kinematic evolution of the Macquarie Plate: a case study for the fragmentation of oceanic lithosphere. Earth Planet. Sci. Lett. 478, 132-142. https://doi.org/10.1016/j. epsl.2017.08.035.

Chuang, L., Bostock, M., Wech, A., Plourde, A., 2017. Plateau subduction, intraslab seismic ity, and the Denali (Alaska) volcanic gap. Geology 45, 647-650. https://doi.org/ 10.1130/G38867.1.

Clague, D., Rubin, J., Brackett, R., 1981. The Age and Origin of the Garnet Amphibolite underlying the Thetford Mines Ophiolite, Quebec. Can. J. Earth Sci. 18, 469-486. https:// doi.org/10.1139/e81-041.

Cliff, R.A., Barnicoat, A.C., Inger, S., 2004. Early Tertiary eclogite facies metamorphism in the Monviso Ophiolite: early tertiary eclogite facies metamorphism. J. Metamorph. Geol. 16, 447-455. https://doi.org/10.1111/j.1525-1314.1998.00147.x.

Clift, P., Vannucchi, P., 2004. Controls on tectonic accretion versus erosion in subduction zones: implications for the origin and recycling of the continental crust. Rev. Geophys. 42. https://doi.org/10.1029/2003RG000127.

Cloos, Mark, 1992. Thrust-type subduction-zone earthquakes and seamount asperities - a physical model for seismic rupture. Geology 20 (7), 601-604. https://doi.org/ 10.1130/0091-7613.

Cloos, M., 1985. Thermal evolution of convergent plate margins - thermal modeling and reevaluation of isotopic Ar-ages for blueschists in the Franciscan complex of California. Tectonics 4, 421-433. https://doi.org/10.1029/TC004i005p00421.

Cloos, M., 1982. Flow melanges - numerical modeling and geologic constraints on their origin in the Franciscan subduction complex, California. Geol. Soc. Am. Bull. 93, 330-345. https://doi.org/10.1130/0016-7606(1982)93<330:FMNMAG>2.0.CO;2.

Cloos, M., Shreve, R., 1988a. Subduction-channel model of prism accretion, melange formation, sediment subduction, and subduction erosion at convergent plate margins .1. Background and description. Pure Appl. Geophys. 128, 455-500. https://doi.org/ 10.1007/BF00874548.

Cloos, M., Shreve, R., 1988b. Subduction-channel model of prism accretion, melange formation, sediment subduction, and subduction erosion at convergent plate margins 2. Implications and discussion. Pure Appl. Geophys. 128, 501-545. https://doi.org/ 10.1007/BF00874549.

Cluzel, D., Aitchison, J.C., Picard, C., 2001. Tectonic accretion and underplating of mafic terranes in the Late Eocene intraoceanic fore-arc of New Caledonia (Southwest Pacific): geodynamic implications. Tectonophysics 340, 23-59. https://doi.org/10.1016/ S0040-1951(01)00148-2

Codillo, E.A., Le Roux, V., Marschall, H.R., 2018. Arc-like magmas generated by melangeperidotite interaction in the mantle wedge. Nat. Commun. 9, 2864. https://doi.org/ 10.1038/s41467-018-05313-2.

Collett, S., Stipska, P., Kusbach, V., Schulmann, K., Marciniak, G., 2017. Dynamics of Saxothuringian subduction channel/wedge constrained by phase-equilibria modelling and micro-fabric analysis. J. Metamorph. Geol. 35, 253-280. https://doi.org/ 10.1111/jmg.12226.

Collins, N.C., Bebout, G.E., Angiboust, S., Agard, P., Scambelluri, M., Crispini, L., John, T. 2015. Subduction zone metamorphic pathway for deep carbon cycling: II. Evidence from HP/UHP metabasaltic rocks and ophicarbonates. Chem. Geol. 412, 132-150. https://doi.org/10.1016/j.chemgeo.2015.06.012.

Contreras-Reyes, E., Maksymowicz, A., Lange, D., Grevemeyer, I., Muñoz-Linford, P., Moscoso, E., 2017. On the relationship between structure, morphology and large coseismic slip: a case study of the M w 8.8 Maule, Chile 2010 earthquake. Earth Planet. Sci. Lett. 478, 27-39.

Cook-Kollars, J., Bebout, G.E., Collins, N.C., Angiboust, S., Agard, P., 2014. Subduction zone metamorphic pathway for deep carbon cycling: I. Evidence from HP/UHP metasedimentary rocks, Italian Alps. Chem. Geol. 386, 31-48. https://doi.org/ 10.1016/j.chemgeo.2014.07.013.

Corbi, F., Funiciello, F., Moroni, M., van Dinther, Y., Mai, P.M., Dalguer, L.A., Faccenna, C., 2013. The seismic cycle at subduction thrusts: 1 . Insights from laboratory models J. Geophys. Res.-Solid Earth 118, 1483-1501. https://doi.org/10.1029/2012JB009481.

Cowan, D.S., 1978. Origin of blueschist-bearing chaotic rocks in the Franciscan complex San Simeon, California. GSA Bull. 89, 1415-1423. https://doi.org/10.1130/00167606(1978)89<1415:OOBCRI>2.0.CO;2.

Cowan, R.J., Searle, M.P., Waters, D.J., 2014. Structure of the metamorphic sole to the Oman Ophiolite, Sumeini Window and Wadi Tayyin: implications for ophiolite obduction processes. In: Rollinson, H.R., Searle, M.P., Abbasi, I.A., AlLazki, A.I. AlKindi, M.H. (Eds.), Tectonic Evolution of the Oman Mountains. Geological Soc Publishing House, Bath, pp. 155-175.

Crameri, F., Conrad, C.P., Montési, L., Lithgow-Bertelloni, C.R., 2018. The dynamic life of an oceanic plate. Tectonophysics 
Deville, E., Fudral, S., Lagabrielle, Y., Marthaler, M., Sartori, M., 1992. From oceanic closure to continental collision: A synthesis of the" Schistes lustrés" metamorphic complex of the Western Alps. Geol. Soc. Am. Bull. 104 (2), 127-139.

Deseta, N., Ashwal, L.D., Andersen, T.B., 2014. Initiating intermediate-depth earthquakes: insights from a HP-LT ophiolite from Corsica. Lithos 206, 127-146. https://doi.org/ 10.1016/j.lithos.2014.07.022

Despaigne-Díaz, A.I., García Casco, A., Cáceres Govea, D., Wilde, S.A., Millán Trujillo, G., 2017. Structure and tectonic evolution of the southwestern Trinidad dome, Escambray complex, Central Cuba: insights into deformation in an accretionary wedge. Tectonophysics 717, 139-161. https://doi.org/10.1016/j. tecto.2017.07.024.

Despaigne-Diaz, A.I., Garcia-Casco, A., Caceres Govea, D., Jourdan, F., Wilde, S.A., Millan Trujillo, G., 2016. Twenty-five million years of subduction-accretion-exhumation during the late cretaceous-tertiary in the Northwestern Caribbean: the Trinidad Dome Escambray complex, Central Cuba. Am. J. Sci. 316, 203-240. https://doi.org/10.2475/ 03.2016.01.

Dewey, J.F., Casey, J.F., 2013. The sole of an ophiolite: the Ordovician Bay of Islands Complex, Newfoundland. J. Geol. Soc. 170 (5), 715-722.

Dragovic, B., Samanta, L.M., Baxter, E.F., Selverstone, J., 2012. Using garnet to constrain the duration and rate of water-releasing metamorphic reactions during subduction: an example from Sifnos, Greece. Chem. Geol. 314, 9-22. https://doi.org/10.1016/j. chemgeo.2012.04.016.

Droop, G.T.R., Karakaya, M.Q., Eren, Y., Karakaya, N., 2005. Metamorphic evolution of blueschists of the Altinekin complex, Konya area, south Central Turkey. Geol. J. 40 127-153. https://doi.org/10.1002/gj.1000.

Duesterhoeft, E., Quinteros, J., Oberhänsli, R., Bousquet, R., de Capitani, C., 2014. Relative impact of mantle densification and eclogitization of slabs on subduction dynamics: a numerical thermodynamic/thermokinematic investigation of metamorphic density evolution. Tectonophysics 637, 20-29. https://doi.org/10.1016/j.tecto.2014.09.009.

Dumitru, T.A., Wakabayashi, J., Wright, J.E., Wooden, J.L., 2010. Early cretaceous transition from nonaccretionary behavior to strongly accretionary behavior within the Franciscan subduction complex. Tectonics 29, TC5001. https://doi.org/10.1029/ 2009TC002542.

Ellis, S., Fagereng, A., Barker, D., Henrys, S., Saffer, D., Wallace, L., Williams, C., Harris, R. 2015. Fluid budgets along the northern Hikurangi subduction margin, New Zealand: the effect of a subducting seamount on fluid pressure. Geophys. J. Int. 202, 277-297. https://doi.org/10.1093/gji/ggv127.

Emry, E.L., Wiens, D.A., 2015. Incoming plate faulting in the Northern and Western Pacific and implications for subduction zone water budgets. Earth Planet. Sci. Lett. 414, 176-186. https://doi.org/10.1016/j.epsl.2014.12.042.

Enami, M., 1983. Petrology of Pelitic Schists in the Oligoclase-Biotite Zone of the Sambagawa Metamorphic Terrain, Japan-Phase-Equilibria in the highest grade zone of a high-pressure intermediate type of metamorphic belt. J. Metamorph. Geol. 1 , 141-161. https://doi.org/10.1111/j.1525-1314.1983.tb00269.x.

Enami, M., Wallis, S., Banno, Y., 1994. Paragenesis of sodic pyroxene-bearing quartz schists - implications for the P-T history of the Sambagawa Belt. Contrib. Mineral. Petrol. 116, 182-198. https://doi.org/10.1007/BF00310699.

Encarnacion, J.P., Essene, E.J., Mukasa, S.B., Hall, C.H., 1995. High pressure and temperature subophiolitic kyanite-garnet amphibolites generated during initiation of mid tertiary subduction, Palawan, Philippines. J. Petrol. 36, 1481-1503.

England, P., Holland, T., 1979. Archimedes and the Tauern Eclogites - role of Buoyancy in the preservation of exotic eclogite blocks. Earth Planet. Sci. Lett. 44, 287-294. https:// doi.org/10.1016/0012-821X(79)90177-8.

Ernst, W.G., 1984. Californian blueschists, subduction, and the significance of tectonostratigraphic terranes. Geology 12, 436-440. https://doi.org/10.1130/00917613.

Escuder-Viruete, J., Perez-Estaun, A., 2006. Subduction-relatedP-T path for eclogites and garnet glaucophanites from the Samana Peninsula basement complex, northern Hispaniola. Int. J. Earth Sci. 95, 995-1017. https://doi.org/10.1007/s00531-006-0079-5.

Escuder-Viruete, J., Perez-Estaun, A., Gabites, J., Suarez-Rodriguez, A., 2011. Structural development of a high-pressure collisional accretionary wedge: the Samana complex Northern Hispaniola. J. Struct. Geol. 33, 928-950. https://doi.org/10.1016/j. jsg.2011.02.006

Escuder-Viruete, J., Valverde-Vaquero, P., Rojas-Agramonte, Y., Jabites, J., Perez-Estaun, A. 2013. From intra-oceanic subduction to arc accretion and arc-continent collision: Insights from the structural evolution of the Rio San Juan metamorphic complex, northern Hispaniola. J. Struct. Geol. 46, 34-56. https://doi.org/10.1016/j.jsg.2012.10.008.

Faccenda, M., 2014. Water in the slab: a trilogy. Tectonophysics 614,1-30. https://doi.org/ 10.1016/j.tecto.2013.12.020.

Fagereng, A., 2013. On stress and strain in a continuous-discontinuous shear zone undergoing simple shear and volume loss. J. Struct. Geol. 50, 44-53. https://doi.org/ 10.1016/j.jsg.2012.02.016.

Fagereng, A., 2011a. Geology of the seismogenic subduction thrust interface. In: Fagereng, A., Toy, V.G., Rowland, J.V. (Eds.), Geology of the Earthquake Source: A Volume in Honour of Rick Sibson. Geological Soc Publishing House, Bath, pp. 55-76.

Fagereng, A., 2011b. Fractal vein distributions within a fault-fracture mesh in an exhumed accretionary melange, Chrystalls Beach complex, New Zealand. J. Struct. Geol. 33, 918-927. https://doi.org/10.1016/j.jsg.2011.02.009.

Fagereng, A., Cooper, A.F., 2010a. The metamorphic history of rocks buried, accreted and exhumed in an accretionary prism: an example from the Otago Schist, New Zealand. J. Metamorph. Geol. 28, 935-954. https://doi.org/10.1111/j.1525-1314.2010.00900.x

Fagereng, A., Cooper, A.F., 2010b. Petrology of metabasalts from the Chrystalls Beach accretionary melange - implications for tectonic setting and terrane origin. N. Z. J. Geol. Geophys. 53, 57-70. https://doi.org/10.1080/00288301003631806.

Fagereng, A.., den Hartog, S.A., 2017. Subduction megathrust creep governed by pressure solution and frictional-viscous flow. Nat. Geosci. 10, 51-57.
Fagereng, A., Diener, J.F.A., 2011. Non-volcanic tremor and discontinuous slab dehydration. Geophys. Res. Lett. 38, L15302. https://doi.org/10.1029/2011GL048214.

Fagereng, A., Ellis, S., 2009. On factors controlling the depth of interseismic coupling on the Hikurangi subduction interface, New Zealand. Earth Planet. Sci. Lett. 278, 120-130. https://doi.org/10.1016/j.epsl.2008.11.033.

Fagereng, A., Harris, C., 2014. Interplay between fluid flow and fault-fracture mesh generation within underthrust sediments: geochemical evidence from the Chrystalls Beach complex, New Zealand. Tectonophysics 612, 147-157. https://doi.org/10.1016/j. tecto.2013.12.002.

Fagereng, A., Hillary, G.W.B., Diener, J.F.A., 2014. Brittle-viscous deformation, slow slip, and tremor. Geophys. Res. Lett. 41, 4159-4167. https://doi.org/10.1002/ 2014 GL060433.

Fagereng, A., Remitti, F., Sibson, R.H., 2011. Incrementally developed slickenfibers - geological record of repeating low stress-drop seismic events? Tectonophysics 510 , 381-386. https://doi.org/10.1016/j.tecto.2011.08.015.

Fagereng, A., Sibson, R.H., 2010. Melange rheology and seismic style. Geology 38, 751-754. https://doi.org/10.1130/G30868.1.

Fagereng, A., Toy, V.G., 2011. Geology of the earthquake source: an introduction, In: Fagereng, A., Toy, V. G., Rowland, J.V. (Eds.), Geology of the Earthquake Source: A Volume in Honour of Rick Sibson. Geological Soc Publishing House, Bath, pp. 1-16.

Farahat, E.S., 2011. Geotectonic significance of Neoproterozoic amphibolites from the Central Eastern Desert of Egypt: a possible dismembered sub-ophiolitic metamorphic sole. Lithos 125, 781-794. https://doi.org/10.1016/j.lithos.2011.04.009.

Faulkner, D.R., Jackson, C.A.L., Lunn, R.J., Schlische, R.W., Shipton, Z.K., Wibberley, C.A.J., Withjack, M.O., 2010. A review of recent developments concerning the structure, mechanics and fluid flow properties of fault zones. J. Struct. Geol. 32, 1557-1575. https:// doi.org/10.1016/j.jsg.2010.06.009.

Federico, L., Capponi, G., Crispini, L., Scambelluri, M., 2004. Exhumation of alpine highpressure rocks: insights from petrology of eclogite clasts in the Tertiary Piedmontese basin (Ligurian Alps, Italy). Lithos 74, 21-40. https://doi.org/10.1016/j. lithos.2003.12.001.

Feenstra, A., Petrakakis, K., Rhede, D., 2007. Variscan relicts in Alpine high-P pelitic rocks from Samos (Greece): evidence from multi-stage garnet and its included minerals. J. Metamorph. Geol. 25, 1011-1033. https://doi.org/10.1111/j.15251314.2007.00741.x.

Feininger, T., 1980. Eclogite and related high-pressure regional metamorphic rocks from the Andes of Ecuador. J. Petrol. 21, 107. https://doi.org/10.1093/petrology/21.1.107.

Festa, A., Dilek, Y., Pini, G.A., Codegone, G., Ogata, K., 2012. Mechanisms and processes of stratal disruption and mixing in the development of mélanges and broken formations: redefining and classifying mélanges. Tectonophys. Chaos Geodyn. 568-569, 7-24. https://doi.org/10.1016/j.tecto.2012.05.021.

Fisher, D.M., Brantley, S.L., 2014. The role of silica redistribution in the evolution of slip instabilities along subduction interfaces: constraints from the Kodiak accretionary complex, Alaska. J. Struct. Geol. 69, 395-414. https://doi.org/10.1016/j.jsg.2014.03.010.

Fitzherbert, J.A., Clarke, G.L., Powell, R., 2003. Lawsonite-omphacite-bearing metabasites of the Pam Peninsula, NE New Caledonia: evidence for disrupted blueschist- to eclogite-facies conditions. J. Petrol. 44, 1805-1831. https://doi.org/10.1093/petrology/egg060.

Frank, W.B., Shapiro, N.M., Husker, A.L., Kostoglodov, V., Bhat, H.S., Carnpillo, M., 2015. Along-faultpore-pressure evolution during a slow-slip event in Guerrero, Mexico. Earth Planet. Sci. Lett. 413, 135-143. https://doi.org/10.1016/j.epsl.2014.12.051.

Freed, A.M., Hashima, A., Becker, T.W., Okaya, D.A., Sato, H., Hatanaka, Y., 2017. Resolving depth-dependent subduction zone viscosity and afterslip from postseismic displacements following the 2011 Tohoku-oki, Japan earthquake. Earth Planet. Sci. Lett. 459, 279-290. https://doi.org/10.1016/j.epsl.2016.11.040.

Frezzotti, M.L., Selverstone, J., Sharp, Z.D., Compagnoni, R., 2011. Carbonate dissolution during subduction revealed by diamond-bearing rocks from the Alps. Nat. Geosci. 4, 703-706. https://doi.org/10.1038/NGEO1246.

Friederich, W., Lambrecht, L., Stoeckhert, B., Wassmann, S., Moos, C., 2014. Seismic visibility of a deep subduction channel - insights from numerical simulation of high-frequency seismic waves emitted from intermediate depth earthquakes. Solid Earth 5, 141-159. https://doi.org/10.5194/se-5-141-2014.

Fujiwara, T., Kodaira, S., No, T., Kaiho, Y., Takahashi, N., Kaneda, Y., 2011. The 2011 Tohoku-Oki Earthquake: displacement reaching the Trench Axis. Science 334, 1240. https://doi.org/10.1126/science.1211554.

Gabriele, P., Ballevre, M., Jaillard, E., Hernandez, J., 2003. Garnet-chloritoid-kyanite metapelites from the Raspas complex (SW Ecuador): a key eclogite-facies assemblage. Eur. J. Mineral. 15, 977-989. https://doi.org/10.1127/0935-1221/2003/00150977.

Gaggero, L., Marroni, M., Pandolfi, L., Buzzi, L., 2009. Modeling the oceanic lithosphere obduction: constraints from the metamorphic sole of mirdita ophiolites (northern Albania). Ofioliti 34, 17-42.

Gao, X., Wang, K., 2017. Rheological separation of the megathrust seismogenic zone and episodic tremor and slip. Nature 543, 416.

Gao, X., Wang, K., 2014. Strength of stick-slip and creeping subduction megathrusts from heat flow observations. Science 345, 1038-1041.

Garcia-Casco, A., Iturralde-Vincent, M.A., Pindell, J., 2008a. Latest cretaceous collision/accretion between the Caribbean plate and caribeana: origin of metamorphic terranes in the greater Antilles. Int. Geol. Rev. 50, 781-809. https://doi.org/10.2747/00206814.50.9.781.

Garcia-Casco, A., Lazaro, C., Rojas-Agramonte, Y., Kroener, A., Torres-Roldan, R.L., Nunez, K. Neubauer, F., Millan, G., Blanco-Quintero, I., 2008b. Partial melting and counterclockwise P-T path of subducted oceanic crust (Sierra del Convento Melange, Cuba). J. Petrol. 49, 129-161. https://doi.org/10.1093/petrology/egm074. 
Garcia-Casco, A., Torres-Roldan, R.L., Iturralde-Vinent, M.A., Millan, G., Nunez Cambra, K, Lazaro, C., Rodriguez Vega, A., 2006. High pressure metamorphism of ophiolites in Cuba. Geol. Acta 4, 63-88.

Garcia-Casco, A., Torres-Roldan, R.L., Millan, G., Monié, P., Schneider, J., 2002. Oscillatory zoning in eclogitic garnet and amphibole, Northern Serpentinite Melange, Cuba: a record of tectonic instability during subduction? J. Metamorph. Geol. 20, 581-598. https://doi.org/10.1046/j.1525-1314.2002.00390.x.

Geersen, J., Ranero, C.R., Barckhausen, U., Reichert, C., 2015. Subducting seamounts control interplate coupling and seismic rupture in the 2014 Iquique earthquake area. Nat. Commun. 6, 8267.

Gerya, T.V., Perchuk, L.L., Burg, J.-P., 2008. Transient hot channels: perpetrating and regurgitating ultrahigh-pressure, high-temperaturecrust-mantle associations in collision belts. Lithos 103, 236-256. https://doi.org/10.1016/j.lithos.2007.09.017.

Gerya, T.V., Stöckhert, B., Perchuk, A.L., 2002. Exhumation of high-pressure metamorphic rocks in a subduction channel: a numerical simulation. Tectonics 21. https://doi.org/ 10.1029/2002TC001406 6-1-6-19.

Glodny, J., Lohrmann, J., Echtler, H., Grafe, K., Seifert, W., Collao, S., Figueroa, O., 2005. Internal dynamics of a paleoaccretionary wedge: insights from combined isotope tectonochronology and sandbox modelling of the South-CentralChilean forearc. Earth Planet. Sci. Lett. 231, 23-39. https://doi.org/10.1016/j.epsl.2004.12.014.

Gnos, E., 1998. Peak metamorphic conditions of garnet amphibolites beneath the Semail Ophiolite: implications for an inverted pressure gradient. Int. Geol. Rev. 40, 281-304. https://doi.org/10.1080/00206819809465210.

Gnos, E., Kurz, D., 1994. Sapphirine-Quartz and Sapphirine-Corundum assemblages in metamorphic rocks associated with the Semail Ophiolite (united-Arab-Emirates). Contrib. Mineral. Petrol. 116, 398-410. https://doi.org/10.1007/BF00310907.

Gorczyk, W., Guillot, S., Gerya, T.V., Hattori, K., 2007. Asthenospheric upwelling, oceanic slab retreat, and exhumation of UHP mantle rocks: insights from Greater Antilles. Geophys. Res. Lett. 34 (21), L21309. https://doi.org/10.1029/2007GL031059.

Govers, R., Furlong, K.P., van de Wiel, L., Herman, M.W., Broerse, T., 2018. The geodetic signature of the earthquake cycle at subduction zones: model constraints on the deep processes. Rev. Geophys. 56, 6-49. https://doi.org/10.1002/2017RG000586.

Gratier, J.-P., Dysthe, D.K., Renard, F., 2013. Chapter2 - the role of pressure solution creep in the ductility of the Earth's Upper Crust. In: Dmowska, R. (Ed.), Advances in Geophysics, Advances in Geophysics. Elsevier, pp. 47-179 https://doi.org/10.1016/ B978-0-12-380940-7.00002-0.

Grigull, S., Krohe, A., Moos, C., Wassmann, S., Stoeckhert, B., 2012. "Order from chaos": a field-based estimate on bulk rheology of tectonic melanges formed in subduction zones. Tectonophysics 568, 86-101. https://doi.org/10.1016/j.tecto.2011.11.004.

Groppo, C., Castelli, D., 2010. Prograde P-T Evolution of a Lawsonite Eclogite from the Monviso Meta-ophiolite (Western Alps): Dehydration and Redox Reactions during Subduction of Oceanic FeTi-oxide Gabbro. J. Petrol. 51, 2489-2514. https://doi.org/ 10.1093/petrology/egq065.

Groppo, C., Rolfo, F., Sachan, H.K., Rai, S.K., 2016. Petrology of blueschist from the Western Himalaya (Ladakh, NWIndia): exploring the complex behavior of a lawsonite-bearing system in a paleo-accretionary setting. Lithos 252-253, 41-56. https://doi.org/ 10.1016/j.lithos.2016.02.014.

Groppo, C., Beltrando, M., Compagnoni, R., 2009. The P-T path of the ultra-high pressure Lago Di Cignana and adjoining high-pressuremeta-ophiolitic units: insights into the evolution of the subducting Tethyan slab. J. Metamorph. Geol. 27, 207-231. https:// doi.org/10.1111/j.1525-1314.2009.00814.x.

Grove, M., Bebout, G.E., 1995. Cretaceous tectonic evolution of coastal southern California: Insights from the Catalina Schist. Tectonics 14, 1290-1308. https://doi.org/10.1029/ 95TC01931.

Grove, M., Bebout, G.E., Jacobson, C.E., Barth, A.P., Kimbrough, D.L., King, R.L., Zou, H., Lovera, O.M., Mahoney, B.J., Gehrels, G.E., 2008. The Catalina Schist: evidence for middle Cretaceous subduction erosion of southwestern North America. In: Draut, A.E., Clift, P.D., Scholl, D.W. (Eds.), Formation and Applications of the Sedimentary Record in Arc Collision Zones. Geological Soc Amer Inc, Boulder, pp. 335-361.

Guillot, S., Hattori, K., Agard, P., Schwartz, S., Vidal, O., 2009. Exhumation processes in oceanic and continental subduction contexts: a review. In: Lallemand, S., Funiciello, F. (Eds.), Subduction Zone Geodynamics. Springer-Verlag Berlin, Berlin (pp.175-+).

Guillot, S., Schwartz, S., Reynard, B., Agard, P., Prigent, C., 2015. Tectonic significance of serpentinites. Tectonophysics 646, 1-19. https://doi.org/10.1016/j.tecto.2015.01.020.

Guilmette, C., Hebert, R., Dostal, J., Indares, A., Ullrich, T., Bedard, E., Wang, C., 2012. Discovery of a dismembered metamorphic sole in the Saga ophiolitic melange, South Tibet: Assessing an Early Cretaceous disruption of the Neo-Tethyansupra-subduction zone and consequences on basin closing. Gondwana Res. 22, 398-414. https://doi. org/10.1016/j.gr.2011.10.012.

Hacker, B.R., Gerya, T.V., 2013. Paradigms, new and old, for ultrahigh-pressure tectonism. Tectonophysics 603, 79-88. https://doi.org/10.1016/j.tecto.2013.05.026.

Hacker, B.R., Kelemen, P.B., Behn, M.D., 2011. Differentiation of the continental crust by relamination. Earth Planet. Sci. Lett. 307, 501-516. https://doi.org/10.1016/j. epsl.2011.05.024.

Hacker, B.R., Peacock, S.M., Abers, G.A., Holloway, S.D., 2003. Subduction factory 2. Are intermediate-depth earthquakes in subducting slabs linked to metamorphic dehydration reactions? J. Geophys. Res. Solid Earth 108

Haeussler, P.J., Armstrong, P.A., Liberty, L.M., Ferguson, K.M., Finn, S.P., Arkle, J.C., Pratt, T.L., 2015. Focused exhumation along megathrust splay faults in Prince William Sound, Alaska. Quat. Sci. Rev. 113, 8-22. https://doi.org/10.1016/j.quascirev.2014.10.013.

Hansen, R.T., Bostock, M.G., Christensen, N.I., 2012. Nature of the low velocity zone in Cascadia from receiver function waveform inversion. Earth Planet. Sci. Lett. 337, 25-38.

Hayes, G.P., Furlong, K.P., Ammon, C.J., 2009. Intraplate deformation adjacent to the Macquarie Ridge south of New Zealand-the tectonic evolution of a complex plate boundary. Tectonophysics 463, 1-14. https://doi.org/10.1016/j.tecto.2008.09.024.
Hayman, N.W., Lavier, L.L., 2014. The geologic record of deep episodic tremor and slip. Geology 42, 195-198. https://doi.org/10.1130/G34990.1.

Hilairet, N., Reynard, B., 2008. Stability and dynamics of serpentinite layer in subduction zone. Tectonophysics https://doi.org/10.1016/j.tecto.2008.10.005.

Hilairet, N., Reynard, B., Wang, Y., Daniel, I., Merkel, S., Nishiyama, N., Petitgirard, S., 2007. High-pressure Creep of Serpentine, Interseismic Deformation, and Initiation of Subduction. Science 318, 1910-1913. https://doi.org/10.1126/science.1148494.

Hirsch, D.M., Babcock, R.S., 2009. Spatially heterogeneous burial and high-P/T metamorphism in the Crescent Formation, Olympic Peninsula,Washington. Am. Miner. 94 1103-1110. https://doi.org/10.2138/am.2009.3187.

Hounslow, M.W., Domeier, M., Biggin, A.J., 2018. Subduction flux modulates the geomagnetic polarity reversal rate. Tectonophysics $742,34-49$

Huet, B., Yamato, P., Grasemann, B., 2014. The Minimized Power Geometric model: an analytical mixing model for calculating polyphase rock viscosities consistent with experimental data. J. Geophys. Res.-Solid Earth 119, 3897-3924. https://doi.org/ 10.1002/2013JB010453.

Hunziker, D., Burg, J.-P., Moulas, E., Reusser, E., Omrani, J., 2017. Formation and preservation of fresh lawsonite: Geothermobarometry of the North Makran Blueschists, Southeast Iran. J. Metamorph. Geol. 35, 871-895. https://doi.org/10.1111/jmg.12259.

Hyndman, R., Yorath, C., Clowes, R., Davis, E., 1990. The Northern Cascadia subduction zone at Vancouver Island - seismic structure and tectonic history. Can. J. Earth Sci. 27, 313-329. https://doi.org/10.1139/e90-030.

Hyndman, R.D., Peacock, S.M., 2003. Serpentinization of the forearc mantle. Earth Planet Sci. Lett. 212, 417-432. https://doi.org/10.1016/S0012-821X(03)00263-2.

Hyppolito, T., Angiboust, S., Juliani, C., Glodny, J., Garcia-Casco, A., Calderon, M., Chopin, C. 2016b. Eclogite-, amphibolite- and blueschist-facies rocks from Diego de Almagro Island (Patagonia): episodic accretion and thermal evolution of the Chilean subduction interface during the Cretaceous. Lithos 264, 422-440. https://doi.org/10.1016/j. lithos.2016.09.001.

Hyppolito, T., Garcia-Casco, A., Juliani, C., Meira, V.T., Hall, C., 2014. Late Paleozoic onset of subduction and exhumation at the western margin of Gondwana (Chilenia Terrane): Counterclockwise P-T paths and timing of metamorphism of deep-seatedgarnet-mica schist and amphibolite of Punta Sirena, Coastal Accretionary Complex, central Chile (34 degrees S). Lithos 206, 409-434. https://doi.org/10.1016/j.lithos.2014.07.023.

Ide, S., Beroza, G.C., Shelly, D.R., Uchide, T., 2007. A scaling law for slow earthquakes. Nature $447,76$.

Ikari, M.J., 2015. Principal slip zones: precursors but not recorders of earthquake slip. Geology 43, 955-958. https://doi.org/10.1130/G37028.1.

Jamieson, R., 1986. P-T paths from high-temperature shear zones beneath Ophiolites J. Metamorph. Geol. 4, 3-22. https://doi.org/10.1111/j.1525-1314.1986.tb00335.x.

Jamieson, R., 1981. Metamorphism during ophiolite emplacement - the petrology of the St-Anthony complex. J. Petrol. 22, 397-449. https://doi.org/10.1093/petrology/ 22.3.397.

John, T., Gussone, N., Podladchikov, Y.Y., Bebout, G.E., Dohmen, R., Halama, R., Klemd, R. Magna, T., Seitz, H.-M., 2012. Volcanic arcs fed by rapid pulsed fluid flow through subducting slabs. Nat. Geosci. 5, 489-492. https://doi.org/10.1038/ngeo1482.

John, T., Schenk, V., 2006. Interrelations between intermediate-depth earthquakes and fluid flow within subducting oceanic plates: constraints from eclogite facies pseudotachylytes. Geology 34, 557-560. https://doi.org/10.1130/G22411.1.

John, T., Scherer, E.E., Schenk, V., Herms, P., Halama, R., Garbe-Schoenberg, D., 2010 Subducted seamounts in an eclogite-facies ophiolite sequence: the Andean Raspas complex, SWEcuador. Contrib. Mineral. Petrol. 159, 265-284. https://doi.org/ 10.1007/s00410-009-0427-0.

Jolivet, L., Faccenna, C., Agard, P., de Lamotte, D.F., Menant, A., Sternai, P., Guillocheau, F., 2016. Neo-Tethys geodynamics and mantle convection: from extension to compression in Africa and a conceptual model for obduction1. Can. J. Earth Sci. 53, 1190-1204 https://doi.org/10.1139/cjes-2015-0118.

Jolivet, L., Faccenna, C., Goffe, B., Burov, E., Agard, P., 2003. Subduction tectonics and exhumation of high-pressure metamorphic rocks in the Mediterranean orogens. Am. J. Sci. 303, 353-409. https://doi.org/10.2475/ajs.303.5.353.

Kaneko, Y., Avouac, J.-P., Lapusta, N., 2010. Towards inferring earthquake patterns from geodetic observations of interseismic coupling. Nat. Geosci. 3, 363.

Kimura, G., Hamahashi, M., Okamoto, S., Yamaguchi, A., Kameda, J., Raimbourg, H. Hamada, Y., Yamaguchi, H., Shibata, T., 2013. Hanging wall deformation of a seismogenic megasplay fault in an accretionary prism: the Nobeoka Thrust in southwestern Japan. J. Struct. Geol. 52, 136-147. https://doi.org/10.1016/j.jsg.2013.03.015.

Kimura, G., Kitamura, Y., Hashimoto, Y., Yamaguchi, A., Shibata, T., Ujiie, K., Okamoto, S. 2007. Transition of accretionary wedge structures around the up-dip limit of the seismogenic subduction zone. Earth Planet. Sci. Lett. 255, 471-484. https://doi.org/ 10.1016/j.epsl.2007.01.005.

Kimura, G., Ludden, J., 1995. Peeling oceanic crust in subduction zones. Geology 23 217-220. https://doi.org/10.1130/0091-7613(1995)023<0217:POCISZ>2.3.CO;2.

Kimura, G., Yamaguchi, A., Hojo, M., Kitamura, Y., Kameda, J., Ujiie, K., Hamada, Y., Hamahashi, M., Hina, S., 2012. Tectonic mélange as fault rock of subduction plate boundary. Tectonophys. Chaos Geodyn. 568-569, 25-38. https://doi.org/10.1016/j. tecto.2011.08.025.

Kimura, H., Kasahara, K., Takeda, T., 2009. Subduction process of the Philippine Sea Plate off the Kanto district, Central Japan, as revealed by plate structure and repeating earthquakes. Tectonophysics 472, 18-27. https://doi.org/10.1016/j.tecto.2008.05.012.

Kimura, H., Takeda, T., Obara, K., Kasahara, K., 2010. Seismic evidence for active underplating below the megathrust earthquake zone in Japan. Science 329, 210-212. https://doi.org/10.1126/science.1187115.

Kinoshita, M., Tobin, H.J., 2013. Interseismic stress accumulation at the locked zone of Nankai Trough seismogenic fault off Kii Peninsula. Tectonophysics 600, 153-164. https://doi.org/10.1016/j.tecto.2013.03.015. 
Kita, S., Okada, T., Nakajima, J., Matsuzawa, T., Hasegawa, A., 2006. Existence of a seismic belt in the upper plane of the double seismic zone extending in the along-arc direction at depths of 70-100 km beneath. Geophys. Res. Lett. 33, L24310. https://doi.org/ 10.1029/2006GL028239.

Kitamura, Y., Sato, K., Ikesawa, E., Ikehara-Ohmori, K., Kimura, G., Kondo, H., ... Mukoyoshi, H., 2005. Mélange and its seismogenic roof décollement: A plate boundary fault rock in the subduction zone-An example from the Shimanto Belt, Japan. Tectonics 24 (5).

Kitamura, Y., Kimura, G., 2012. Dynamic role of tectonic melange during interseismic process of plate boundary mega earthquakes. Tectonophysics 568, 39-52. https://doi. org/10.1016/j.tecto.2011.07.008.

Ko, Z.W., Enami, M., Aoya, M., 2005. Chloritoid and barroisite-bearing pelitic schists from the eclogite unit in the Besshi district, Sambagawa metamorphic belt. Lithos 81 79-100. https://doi.org/10.1016/j.lithos.2004.09.018.

Kodaira, S., Noguchi, N., Takahashi, N., Ishizuka, O., Kaneda, Y., 2010. Evolution from forearc oceanic crust to island arc crust: A seismic study along the Izu-Bonin fore arc. J. Geophys. Res.-Solid Earth 115, B09102. https://doi.org/10.1029/2009JB006968.

Konrad-Schmolke, M., O'Brien, P.J., Zack, T., 2011. Fluid migration above a subducted slab -constraints on amount, pathways and major element mobility from partially overprinted eclogite-facies rocks (Sesia Zone, Western Alps). J. Petrol. 52, 457-486. https://doi.org/10.1093/petrology/egq087.

Krebs, M., Maresch, W.V., Schertl, H.-P., Muenker, C., Baumann, A., Draper, G., Idleman, B. Trapp, E., 2008. The dynamics of intra-oceanic subduction zones: a direct comparison between fossil petrological evidence (Rio San Juan complex, Dominican Republic) and numerical simulation. Lithos 103, 106-137. https://doi.org/10.1016/j. lithos.2007.09.003.

Krebs, M., Schertl, H.-P., Maresch, W.V., Draper, G., 2011. Mass flow in serpentinite-hosted subduction channels: P-T-t path patterns of metamorphic blocks in the Rio San Juan melange (Dominican Republic). J. Asian Earth Sci. 42, 569-595. https://doi.org/ 10.1016/j.jseaes.2011.01.011.

Krogh, E., Oh, C., Liou, J., 1994. Polyphase and anticlockwise P-T evolution for franciscan eclogites and blueschists from Jenner, California, USA. J. Metamorph. Geol. 12 121-134. https://doi.org/10.1111/j.1525-1314.1994.tb00008.x.

Krohe, A., 2017. The Franciscan complex (California, USA) - the model case for returnflow in a subduction channel put to the test. Gondwana Res. 45, 282-307. https:// doi.org/10.1016/j.gr.2017.02.003.

Kukowski, N., Lallemand, S.E., Malavieille, J., Gutscher, M.A., Reston, T.J., 2002. Mechanica decoupling and basal duplex formation observed in sandbox experiments with application to the Western Mediterranean Ridge accretionary complex. Mar. Geol. 186 29-42. https://doi.org/10.1016/S0025-3227(02)00171-8.

Kusky, T.M., Windley, B.F., Safonova, I., Wakita, K., Wakabayashi, J., Polat, A., Santosh, M. 2013. Recognition of ocean plate stratigraphy in accretionary orogens through Earth history: a record of 3.8billion years of sea floor spreading, subduction, and accretion. Gondwana Res. 24, 501-547. https://doi.org/10.1016/j.gr.2013.01.004.

Lagabrielle, Y., Brovarone, A.V., Ildefonse, B., 2015. Fossil oceanic core complexes recognized in the blueschist metaophiolites of Western Alps and Corsica. Earth-Sci. Rev. $141,1-26$.

Laurent, V., Jolivet, L., Roche, V., Augier, R., Scaillet, S., Cardello, G.L., 2016. Strain localization in a fossilized subduction channel: insights from the Cycladic Blueschist Unit (Syros, Greece). Tectonophysics 672, 150-169. https://doi.org/10.1016/j. tecto.2016.01.036

Lay, T., Kanamori, H., Ammon, C.J., Koper, K.D., Hutko, A.R., Ye, L., Yue, H., Rushing, T.M., 2012. Depth-varying rupture properties of subduction zone megathrust faults J. Geophys. Res. Solid Earth 117. https://doi.org/10.1029/2011JB009133.

Lazaro, C., Blanco-Quintero, I.F., Rojas-Agramonte, Y., Proenza, J.A., Nunez-Cambra, K. Garcia-Casco, A., 2013. First description of a metamorphic sole related to ophiolite obduction in the northern Caribbean: geochemistry and petrology of the Guira de Jauco Amphibolite complex (eastern Cuba) and tectonic implications. Lithos 179 193-210. https://doi.org/10.1016/j.lithos.2013.08.019.

Lazaro, C., Garcia-Casco, A., Rojas-Agramonte, Y., Kroener, A., Neubauer, F., IturraldeVinent, M., 2009. Fifty-five-million-year history of oceanic subduction and exhumation at the northern edge of the Caribbean plate (Sierra del Convento mElange, Cuba). J. Metamorph. Geol. 27, 19-40. https://doi.org/10.1111/j.15251314.2008.00800.x.

Lewis, J.C., Byrne, T.B., Kanagawa, K., 2013. Evidence for mechanical decoupling of the upper plate at the Nankai subduction zone: Constraints from core-scale faults at NantroSEIZE Sites C0001 and C0002. Geochem. Geophys. Geosyst. 14, 620-633. https://doi.org/10.1029/2012GC004406.

Luoni, P., Rebay, G., Spalla, M.I., Zanoni, D., 2018. UHP Ti-chondrodite in the Zermatt-Saas serpentinite: constraints on a new tectonic scenario. Am. Mineral. 103, 1002-1005. https://doi.org/10.2138/am-2018-6460.

Maekawa, H., Shozul, M., Ishii, T., Fryer, P., Pearce, J., 1993. Blueschist metamorphism in an active subduction zone. Nature 364, 520-523. https://doi.org/10.1038/ 364520a0.

Magott, R., Fabbri, O., Fournier, M., 2016. Subduction zone intermediate-depth seismicity: Insights from the structural analysis of Alpine high-pressureophiolite-hosted pseudotachylyte (Corsica, France). J. Struct. Geol. 87, 95-114. https://doi.org/ 10.1016/j.jsg.2016.04.002.

Marcaillou, B., Collot, J.-Y., 2008. Chronostratigraphy and tectonic deformation of the North Ecuadorian-SouthColombian offshore Manglares forearc basin. Mar. Geol. 255, 30-44. https://doi.org/10.1016/j.margeo.2008.07.003.

Marcaillou, B., Spence, G., Wang, K., Collot, J.-Y., Ribodetti, A., 2008. Thermal segmentation along the $\mathrm{N}$. Ecuador-S, Colombia margin (1-4 degrees $\mathrm{N}$ ): prominent influence of sedimentation rate in the trench. Earth Planet. Sci. Lett. 272, 296-308. https://doi. org/10.1016/j.epsl.2008.04.049.

Marone, C., Richardson, E., 2010. Learning to read fault-slip behavior from fault-zone structure. Geology 38, 767-768. https://doi.org/10.1130/focus082010.1.
Marschall, H.R., Schumacher, J.C., 2012. Arc magmas sourced from melange diapirs in subduction zones. Nat. Geosci. 5, 862-867. https://doi.org/10.1038/NGEO1634.

Marsellos, A.E., Kidd, W.S.F., Garver, J.I., 2010. Extension and exhumation of the Hp/Lt rocks in the hellenic forearc ridge. Am. J. Sci. 310, 1-36. https://doi.org/10.2475/ 01.2010 .01

Maruyama, S., Liou, J.G., Terabayashi, M., 1996. Blueschists and Eclogites of the World and Their Exhumation. Int. Geol. Rev. 38 (6), 485-594. https://doi.org/10.1080/ 00206819709465347

McCaig, A., 1983. P-T conditions during emplacement of the Bay-of-Islands Ophiolite complex. Earth Planet. Sci. Lett. 63, 459-473. https://doi.org/10.1016/0012-821X (83)90118-8.

McCrory, P.A., Wilson, D.S., 2013. A kinematic model for the formation of the Siletz-Crescent forearc terrane by capture of coherent fragments of the Farallon and Resurrection plates. Tectonics 32, 718-736. https://doi.org/10.1002/tect.20045.

McCrory, P.A., Wilson, D.S., Stanley, R.G., 2009. Continuing evolution of the Pacific-Juan de Fuca-NorthAmerica slab window system-a trench-ridge-transform example from the Pacific Rim. Tectonophysics 464, 30-42. https://doi.org/10.1016/j.tecto.2008.01.018.

Meffre, S., Falloon, T.J. Crawford, TJ. Hoernle, K. Hauff, F, Duncan, R.A., Bloomer, S.H. Wright, D.J., 2012. Basalts erupted along the Tongan fore arc during subduction initiation: evidence from geochronology of dredged rocks from the Tonga fore arc and trench. Geochem. Geophys. Geosyst. 13, Q12003. https://doi.org/10.1029/ 2012GC004335.

Melnick, D., Moreno, M., Quinteros, J., Carlos Baez, J., Deng, Z., Li, S., Oncken, O., 2017. The super-interseismic phase of the megathrust earthquake cycle in Chile. Geophys. Res. Lett. 44, 784-791. https://doi.org/10.1002/2016GL071845.

Menant, A., Angiboust, S., Monié, P., Oncken, O., Guigner, J.-M., 2018. Brittle deformation during Alpine basal accretion and the origin of seismicity nests above the subduction interface. Earth Planet. Sci. Lett. 487, 84-93. https://doi.org/10.1016/j. epsl.2018.01.029.

Meneghini, F., Moore, J.C., 2007. Deformation and hydrofracture in a subduction thrust at seismogenic depths: the Rodeo Cove thrust zone, Marin Headlands, California. Geol. Soc. Am. Bull. 119, 174-183. https://doi.org/10.1130/B25807.1.

Messiga, B., Scambelluri, M., Piccardo, G., 1995. Chloritoid-bearing assemblages in Mafic Systems and Eclogite-Facies Hydration of Alpine Mg-Al Metagabbros (Erro-Tobbio Unit, Ligurian Western Alps). Eur. J. Mineral. 7, 1149-1167.

Metois, M., Socquet, A., Vigny, C., 2012. Interseismic coupling, segmentation and mechanical behavior of the central Chile subduction zone. J. Geophys. Res.-Solid Earth 117, B03406. https://doi.org/10.1029/2011JB008736.

Métois, M., Vigny, C., Socquet, A., 2016. Interseismic coupling, megathrust earthquakes and seismic swarms along the Chilean subduction zone (38-18 S). Pure Appl. Geophys. 173, 1431-1449.

Mochizuki, K., Yamada, T., Shinohara, M., Yamanaka, Y., Kanazawa, T., 2008. Weak interplate coupling by seamounts and repeating $\mathrm{M} \sim 7$ earthquakes. Science 321, 1194-1197.

Monié, P., Agard, P., 2009. Coeval blueschist exhumation along thousands of kilometers: Implications for subduction channel processes. Geochem. Geophys. Geosyst. 10 Q07002. https://doi.org/10.1029/2009GC002428.

Moreno, M., Melnick, D., Rosenau, M., Bolte, J., Klotz, J., Echtler, H., Baez, J., Bataille, K., Chen, J., Bevis, M., Hase, H., Oncken, O., 2011. Heterogeneous plate locking in the South-CentralChile subduction zone: Building up the next great earthquake. Earth Planet. Sci. Lett. 305, 413-424. https://doi.org/10.1016/j.epsl.2011.03.025.

Mulcahy, S.R., Starnes, J.K., Day, H.W., Coble, M.A., Vervoort, J.D., 2018. Early onset of Franciscan subduction. Tectonics 37, 1194-1209. https://doi.org/10.1029/2017TC004753.

Nakajima, J., Uchida, N., 2018. Repeated drainage from megathrusts during episodic slow slip. Nat. Geosci. 11, 351-356. https://doi.org/10.1038/s41561-018-0090-z.

Nielsen, S.G., Marschall, H.R., 2017. Geochemical evidence for melange melting in global arcs. Sci. Adv. 3 (4). https://doi.org/10.1126/sciadv.1602402 UNSP e1602402.

Nocquet, J.-M., Jarrin, P., Vallee, M., Mothes, P.A., Grandin, R., Rolandone, F., Delouis, B., Yepes, H., Font, Y., Fuentes, D., Regnier, M., Laurendeau, A., Cisneros, D., Hernandez, S., Sladen, A., Singaucho, J.-C., Mora, H., Gomez, J., Montes, L., Charvis, P., 2017. Supercycle at the Ecuadorian subduction zone revealed after the 2016 Pedernales earthquake. Nat. Geosci. 10, 145. https://doi.org/10.1038/NGEO2864.

Oberhansli, R., Bousquet, R., Moinzadeh, H., Moazzen, M., Arvin, M., 2007. The field of stability of blue jadeite: a new occurrence of jadeitite at Sorkhan, Iran, as a case study. Can. Mineral. 45, 1501-1509. https://doi.org/10.3749/canmin.45.6.1501.

O'Brien, P., 2006. Exhumation of UHP rocks: deciphering the petrologic and geochronologic evidence in Himalayan examples. Vienna (pp. A-10573, EGU06).

Okay, A.I., Harris, N.B.W., Kelley, S.P., 1998. Exhumation of blueschists along a Tethyan suture in Northwest Turkey. Tectonophysics 285, 275-299. https://doi.org/10.1016/ S0040-1951(97)00275-8.

Oleskevich, D.A., Hyndman, R.D., Wang, K., 1999. The updip and downdip limits to great subduction earthquakes: thermal and structural models of Cascadia, South Alaska, SWJapan, and Chile. J. Geophys. Res. Solid Earth 104, 14965-14991.

Omrani, H., Moazzen, M., Oberhaensli, R., Moslempour, M.E., 2017. Iranshahr blueschist: subduction of the inner Makran oceanic crust. J. Metamorph. Geol. 35, 373-392. https://doi.org/10.1111/jmg.12236.

Oncken, O., Asch, G., Haberland, C., Metchie, J., Sobolev, S., Stiller, M., Yuan, X., Brasse, H., Buske, S., Giese, P., Görze, H.-J., Lueth, S., Scheuber, E., Shapiro, S., Wigger, P., Yoon, M.K., Bravo, P., Vieytes, H., Chong, G., Gonzales, G., Wilke, H.-G., Lüschen, E., Martinez, E., Rössling, R., Ricaldi, E., Rietbrock, A., 2003. Seismic imaging of a convergent continental margin and plateau in the Central Andes (Andean Continental Research Project 1996 (ANCORP’96)). J. Geophys. Res. Solid Earth 108. https://doi.org/10.1029/ 2002JB001771.

Oncken, O., Hindle, D., Kley, J., Elger, K., Victor, P., Schemmann, K., 2006. Deformation of the Central Andean upper plate system - facts, fiction, and constraints for plateau models. In: Oncken, O., Chong, G., Franz, G., Giese, P., Gotze, H.J., Ramos, V.A., 
Strecker, M.R., Wigger, P. (Eds.), Andes: Active Subduction Orogeny. Springer, New York, pp. 3-27.

Ota, T., Kaneko, Y., 2010. Blueschists, eclogites, and subduction zone tectonics: insights from a review of Late Miocene blueschists and eclogites, and related young highpressure metamorphic rocks. Gondwana Res. 18, 167-188. https://doi.org/10.1016/ j.gr.2010.02.013

Pabst, S., Zack, T., Savoy, I.P., Ludwig, T., Rost, D., Tonarini, S., Vicenzi, E.P., 2012. The fate of subducted oceanic slabs in the shallow mantle: insights from boron isotopes and light element composition of metasomatized blueschists from the Mariana forearc. Lithos 132, 162-179. https://doi.org/10.1016/j.lithos.2011.11.010.

Pamic, J., Tomljenovic, B., Balen, D., 2002. Geodynamic and petrogenetic evolution of Alpine ophiolites from the central and NW Dinarides: an overview. Lithos 65, 113-142. https://doi.org/10.1016/S0024-4937(02)00162-7.

Paulatto, M., Laigle, M., Galve, A., Charvis, P., Sapin, M., Bayrakci, G., Evain, M., Kopp, H., 2017. Dehydration of subducting slow-spread oceanic lithosphere in the Lesser Antilles. Nat. Commun. 8, 15980. https://doi.org/10.1038/ncomms15980.

Peacock, S.M., Hyndman, R.D., 1999. Hydrous minerals in the mantle wedge and the maximum depth of subduction thrust earthquakes. Geophys. Res. Lett. 26, 2517-2520. https://doi.org/10.1029/1999GL900558.

Peng, Z., Gomberg, J., 2010. An integrated perspective of the continuum between earthquakes and slow-slip phenomena. Nat. Geosci. 3, 599.

Penniston-Dorland, S.C., Kohn, M.J., Manning, C.E., 2015. The global range of subduction zone thermal structures from exhumed blueschists and eclogites: Rocks are hotter than models. Earth Planet. Sci. Lett. 428, 243-254. https://doi.org/10.1016/j. epsl.2015.07.031.

Penniston-Dorland, S.C., Kohn, M.J., Piccoli, P.M., 2018. A melange of subduction temperatures: evidence from $\mathrm{Zr}$-in-rutile thermometry for strengthening of the subduction interface. Earth Planet. Sci. Lett. 482, 525-535. https://doi.org/10.1016/j. epsl.2017.11.005.

Penniston-Dorland, S.C., Sorensen, S.S., Ash, R.D., Khadke, S.V., 2010. Lithium isotopes as a tracer of fluids in a subduction zone mélange: Franciscan complex, CA. Earth Planet. Sci. Lett. 292, 181-190. https://doi.org/10.1016/j.epsl.2010.01.034.

Platt, J., 1993. Exhumation of high-pressure rocks - a review of concepts and processes. Terra Nova 5, 119-133. https://doi.org/10.1111/j.1365-3121.1993.tb00237.x.

Platt, J., 1986. Dynamics of orogenic wedges and the uplift of high-pressure metamorphic rocks. Geol. Soc. Am. Bull. 97, 1037-1053. https://doi.org/10.1130/0016-7606(1986) 97<1037:DOOWAT>2.0.CO;2

Platt, J., 1975. Metamorphic and deformational processes in Franciscan-complex, California - some insights from Catalina Schist Terrane. Geol. Soc. Am. Bull. 86, 1337-1347. https://doi.org/10.1130/0016-7606(1975)86<1337:MADPIT>2.0.CO;2.

Platt, J.P., 2015. Origin of Franciscan blueschist-bearing melange at San Simeon, Central California coast. Int. Geol. Rev. 57, 843-853. https://doi.org/10.1080/ 00206814.2014 .902756

Plunder, A., Agard, P., Chopin, C., Okay, A.I., 2013. Geodynamics of the Tavsanli zone, western Turkey: insights into subduction/obduction processes. Tectonophysics 608 , 884-903. https://doi.org/10.1016/j.tecto.2013.07.028.

Plunder, A., Agard, P., Chopin, C., Pourteau, A., Okay, A.I., 2015. Accretion, underplating and exhumation along a subduction interface: from subduction initiation to continental subduction (Tavşanlı zone, W. Turkey). Lithos 226, 233-254

Plunder, A., Agard, P., Chopin, C., Soret, M., Okay, A.I., Whitechurch, H., 2016. Metamorphic sole formation, emplacement and blueschist facies overprint: early subduction dynamics witnessed by western Turkey ophiolites. Terra Nova 28, 329-339. https:// doi.org/10.1111/ter.12225.

Plunder, A., Agard, P., Dubacq, B., Chopin, C., Bellanger, M., 2012. How continuous and precise is the record of P-T paths? Insights from combined thermobarometry and thermodynamic modelling into subduction dynamics (Schistes Lustres, W. Alps). J. Metamorph. Geol. 30, 323-346. https://doi.org/10.1111/j.15251314.2011.00969.x.

Pourteau, A., Bousquet, R., Vidal, O., Plunder, A., Duesterhoeft, E., Candan, O., Oberhansli, R., 2014. Multistage growth of Fe-Mg-carpholite and Fe-Mg-chloritoid, from field evidence to thermodynamic modelling. Contrib. Mineral. Petrol. 168, 1090. https://doi. org/10.1007/s00410-014-1090-7.

Pourteau, A., Sudo, M., Candan, O., Lanari, P., Vidal, O., Oberhaensli, R., 2013. Neotethys closure history of Anatolia: insights from Ar-40-Ar-39 geochronology and P-T estimation in high-pressure metasedimentary rocks. J. Metamorph. Geol. 31, 585-606. https://doi.org/10.1111/jmg.12034.

Prigent, C., Guillot, S., Agard, P., Lemarchand, D., Soret, M., Ulrich, M., 2018. Transfer of subduction fluids into the deforming mantle wedge during nascent subduction: evidence from trace elements and boron isotopes (Semail ophiolite, Oman). Earth Planet. Sci. Lett. 484, 213-228. https://doi.org/10.1016/j.epsl.2017.12.008.

Raimbourg, H., Augier, R., Famin, V., Gadenne, L., Palazzin, G., Yamaguchi, A., Kimura, G. 2014. Long-term evolution of an accretionary prism: the case study of the Shimanto Belt, Kyushu, Japan. Tectonics 33, 936-959. https://doi.org/10.1002/2013TC003412.

Raimbourg, H., Famin, V., Palazzin, G., Mayoux, M., Jolivet, L., Ramboz, C., Yamaguchi, A., 2018. Fluid properties and dynamics along the seismogenic plate interface. Geosphere 14, 469-491. https://doi.org/10.1130/GES01504.1.

Raimbourg, H., Jolivet, L., Leroy, Y., 2007. Consequences of progressive eclogitization on crustal exhumation, a mechanical study. Geophys. J. Int. 168, 379-401. https://doi. org/10.1111/j.1365-246X.2006.03130.x.

Ranero, C.R., Morgan, J.P., McIntosh, K., Reichert, C., 2003. Bending-related faulting and mantle serpentinization at the Middle America trench. Nature 425, 367-373. https://doi.org/10.1038/nature01961.

Reinecke, T., 1998. Prograde high- to ultrahigh-pressure metamorphism and exhumation of oceanic sediments at Lago di Cignana, Zermatt-Saas Zone, western Alps. Lithos 42 , 147-189. https://doi.org/10.1016/S0024-4937(97)00041-8.
Reynard, B., 2013. Serpentine in active subduction zones. Lithos 178, 171-185. https://doi. org/10.1016/j.lithos.2012.10.012.

Riel, N., Capitanio, F.A., Velic, M., 2017. Numerical modeling of stress and topography coupling during subduction: Inferences on global vs. regional observables interpretation. Tectonophysics.

Rietbrock, A., Waldhauser, F., 2004. A narrowly spaced double-seismic zone in the subducting Nazca plate. Geophys. Res. Lett. 31, L10608. https://doi.org/10.1029/ 2004GL019610.

Rioux, M., Garber, J., Bauer, A., Bowring, S., Searle, M., Kelemen, P., Hacker, B., 2016. Synchronous formation of the metamorphic sole and igneous crust of the Semail ophiolite: New constraints on the tectonic evolution during ophiolite formation from high-precisionU-Pb zircon geochronology. Earth Planet. Sci. Lett. 451, 185-195. https://doi.org/10.1016/j.epsl.2016.06.051.

Rogers, G., Dragert, H., 2003. Episodic tremor and slip on the Cascadia subduction zone: the chatter of silent slip. Science 300, 1942-1943.

Rondenay, S., Abers, G.A., Van Keken, P.E., 2008. Seismic imaging of subduction zone metamorphism. Geology 36, 275-278. https://doi.org/10.1130/G24112A.1.

Rowe, C.D., Moore, J.C., Remitti, F., 2013. The thickness of subduction plate boundary faults from the seafloor into the seismogenic zone. Geology 41, 991-994. https:// doi.org/10.1130/G34556.1.

Ruh, J.B., Le Pourhiet, L., Agard, P., Burov, E., Gerya, T., 2015. Tectonic slicing of subducting oceanic crust along plate interfaces: Numerical modeling. Geochem. Geophys. Geosyst. 16, 3505-3531.

Ruh, J.B., Sallarès, V., Ranero, C.R., Gerya, T., 2016. Crustal deformation dynamics and stress evolution during seamount subduction: high-resolution3-D numerical modeling. J. Geophys. Res. Solid Earth 121, 6880-6902.

Saffer, D.M., Tobin, H.J., 2011. Hydrogeology and mechanics of subduction zone forearcs: fluid flow and pore pressure. Annu. Rev. Earth Planet. Sci. 39, 157-186. https://doi org/10.1146/annurev-earth-040610-133408.

Saffer, D.M., Wallace, L.M., 2015. The frictional, hydrologic, metamorphic and thermal habitat of shallow slow earthquakes. Nat. Geosci. 8, 594-600. https://doi.org/ 10.1038/ngeo2490.

Sage, F., Collot, J.-Y., Ranero, C.R., 2006. Interplate patchiness and subduction-erosion mechanisms: evidence from depth-migrated seismic images at the Central Ecuador convergent margin. Geology 34, 997-1000. https://doi.org/10.1130/G22790A.1.

Saillard, M., Hall, S.R., Audin, L., Farber, D.L., Herail, G., Martinod, J., Regard, V., Finkel, R.C. Bondoux, F., 2009. Non-steadylong-term uplift rates and Pleistocene marine terrace development along the Andean margin of Chile (31 degrees S)inferred from Be-10 dating. Earth Planet. Sci. Lett. 277, 50-63. https://doi.org/10.1016/j.epsl.2008.09.039.

Sallares, V., Ranero, C.R., 2005. Structure and tectonics of the erosional convergent margin off Antofagasta, North Chile (23 degrees 30' S). J. Geophys. Res.-Solid Earth 110, B06101. https://doi.org/10.1029/2004JB003418.

Scambelluri, M., Tonarini, S., 2012. Boron isotope evidence for shallow fluid transfer across subduction zones by serpentinized mantle. Geology 40, 907-910. https://doi. org/10.1130/G33233.1.

Scambelluri, M., Pennacchioni, G., Gilio, M., Bestmann, M., Plumper, O., Nestola, F., 2017. Fossil intermediate-depth earthquakes in subducting slabs linked to differential stress release. Nat. Geosci. 10, 960. https://doi.org/10.1038/s41561-017-0010-7.

Scarsi, M., Malatesta, C., Fornasaro, S., 2018. Lawsonite-bearing eclogite from a tectonic melange in the Ligurian Alps: new constraints for the subduction plate-interface evolution. Geol. Mag. 155, 280-297. https://doi.org/10.1017/S0016756817000395.

Schmalholz, S.M., Podladchikov, Y., 2014. Metamorphism under stress: the problem of relating minerals to depth. Geology 42, 733-734. https://doi.org/10.1130/ focus0822014.1.

Schmalholz, S.M., Podladchikov, Y.Y., 2013. Tectonic overpressure in weak crustal-scale shear zones and implications for the exhumation of high-pressure rocks. Geophys. Res. Lett. 40, 1984-1988. https://doi.org/10.1002/grl.50417.

Schmidt, M.W., Poli, S., 1998. Experimentally based water budgets for dehydrating slabs and consequences for arc magma generation. Earth Planet. Sci. Lett. 163 (1-4), 361-379.

Schmidt, M.W., Poli, S., 2014. Devolatilization during subduction. In: Rudnick, R.L., Holland, H.D., Turekian, K.K. (Eds.), The Crust, Treatise on Geochemistry, Second Edition Elsevier-Pergamon, Oxford, pp. 669-701.

Schneider, J., Bosch, D., Monié, P., Guillot, S., Garcia-Casco, A., Lardeaux, J.M., TorresRoldan, R.L., Trujillo, G.M., 2004. Origin and evolution of the Escambray Massif (Central Cuba): an example of HP/LT rocks exhumed during intraoceanic subduction. J. Metamorph. Geol. 22, 227-247. https://doi.org/10.1111/j.1525-1314.2004.00510.x.

Scholz, C.H., 1998. Earthquakes and friction laws. Nature 391, 37.

Schwartz, S.Y., Rokosky, J.M., 2007. Slow slip events and seismic tremor at circum-Pacific subduction zones. Rev. Geophys. 45.

Searle, M.P., Cox, J., 2002. Subduction zone metamorphism during formation and emplacement of the Semail ophiolite in the Oman Mountains. Geol. Mag. 139, 241-255. https://doi.org/10.1017/S0016756802006532.

Shibakusa, H., Maekawa, H., 1997. Lawsonite-bearing eclogitic metabasites in the Cazadero area, northern California. Mineral. Petrol. 61, 163-180. https://doi.org/ 10.1007/BF01172482.

Shillington, D.J., Becel, A., Nedimovic, M.R., Kuehn, H., Webb, S.C., Abers, G.A., Keranen, K. M., Li, J., Delescluse, M., Mattei-Salicrup, G.A., 2015. Link between plate fabric, hydration and subduction zone seismicity in Alaska. Nat. Geosci. 8. https://doi.org/10.1038/ NGEO2586 961-U98.

Shreve, R.L., Cloos, M., 1986. Dynamics of sediment subduction, melange formation, and prism accretion. J. Geophys. Res. Solid Earth 91 (B10), 10229-10245.

Sibson, R.H., 2013. Stress switching in subduction forearcs: implications for overpressure containment and strength cycling on megathrusts. Tectonophysics 600, 142-152. https://doi.org/10.1016/j.tecto.2013.02.035. 
Singh, S.C., Carton, H., Tapponnier, P., Hananto, N.D., Chauhan, A.P.S., Hartoyo, D., Bayly, M., Moeljopranoto, S., Bunting, T., Christie, P., Lubis, H., Martin, J., 2008. Seismic evidence for broken oceanic crust in the 2004 Sumatra earthquake epicentral region. Nat. Geosci. 1, 777-781. https://doi.org/10.1038/ngeo336.

Singh, S.C., Chauhan, A.P.S., Calvert, A.J., Hananto, N.D., Ghosal, D., Rai, A., Carton, H., 2012 Seismic evidence of bending and unbending of subducting oceanic crust and the presence of mantle megathrust in the 2004 Great Sumatra earthquake rupture zone. Earth Planet. Sci. Lett. 321, 166-176. https://doi.org/10.1016/j.epsl.2012.01.012.

Sobolev, S.V., Muldashev, I.A., 2017. Modeling seismic cycles of great megathrust earthquakes across the scales with focus at postseismic phase. Geochem. Geophys Geosyst. 18 (12), 4387-4408.

Soldner, J., Oliot, E., Schulmann, K., Stipska, P., Kusbach, V., Anczkiewicz, R., 2017. Metamorphic P-T-t-d evolution of (U)HP metabasites from the South Tianshan accretionary complex (NW China) - implications for rock deformation during exhumation in a subduction channel. Gondwana Res. 47, 161-187. https://doi.org/10.1016/j. gr.2016.07.007.

Song, S., Niu, Y., Zhang, L., Wei, C., Liou, J.G., Su, L., 2009. Tectonic evolution of early Paleozoic HP metamorphic rocks in the North Qilian Mountains, NWChina: new perspectives. J. Asian Earth Sci. 35, 334-353. https://doi.org/10.1016/j.jseaes.2008.11.005.

Song, S.G., Zhang, L.F., Niu, Y., Wie, C.J., Liou, J.G., Shu, G.M., 2007. Eclogite and carpholitebearing metasedimentary rocks in the North Qilian suture zone, NWChina: implications for early palaeozoic cold oceanic subduction and water transport into mantle. J. Metamorph. Geol. 25, 547-563. https://doi.org/10.1111/j.1525-1314.2007.00713.x.

Song, T.-R.A., Simons, M., 2003. Large trench-parallel gravity variations predict seismogenic behavior in subduction zones. Science 301, 630-633. https://doi.org/ 10.1126/science.1085557.

Soret, M., Agard, P., Dubacq, B., Plunder, A., Yamato, P., 2017a. Petrological evidence for stepwise accretion of metamorphic soles during subduction infancy (Semail ophiolite, Oman and UAE). J. Metamorph. Geol. 35, 1051-1080. https://doi.org/ $10.1111 /$ jmg.12267.

Soret, M., Agard, P., Dubacq, B., Plunder, A., Yamato, P., 2017b. Petrological evidence for stepwise accretion of metamorphic soles during subduction infancy (Semail ophiolite, Oman and UAE). J. Metamorph. Geol. 35, 1051-1080. https://doi.org/ $10.1111 /$ jmg.12267.

Spandler, C., Pirard, C., 2013. Element recycling from subducting slabs to arc crust: a review. Lithos 170, 208-223. https://doi.org/10.1016/j.lithos.2013.02.016.

Spinelli, G.A., 2014. Long-distance fluid and heat transport in the oceanic crust entering the Nankai subduction zone, NanTroSEIZE transect. Earth Planet. Sci. Lett. 389, 86-94.

St Clair, J., Holbrook, W.S., Van Avendonk, H.J.A., Lizarralde, D., 2016. Along-strike structure of the Costa Rican convergent margin from seismic a refraction/reflection survey: evidence for underplating beneath the inner forearc. Geochem. Geophys. Geosyst. 17, 501-520. https://doi.org/10.1002/2015GC006029.

Stöckhert, B., 2002. Stress and deformation in subduction zones: insight from the record of exhumed metamorphic rocks. Geol. Soc. Lond., Spec. Publ. 200, 255-274.

Author, 2011. Studying the seismogenic coupling zone with a passive seismic array. EOS Trans. Am. Geophys. Union 86, 293-297. https://doi.org/10.1029/2005E0320001.

Syracuse, E.M., van Keken, P.E., Abers, G.A., 2010. The global range of subduction zone thermal models. Phys. Earth Planet. Interiors 183, 73-90. https://doi.org/10.1016/j. pepi.2010.02.004

Taetz, S., John, T., Bröcker, M., Spandler, C., Stracke, A., 2018. Fast intraslab fluid-flow events linked to pulses of high pore fluid pressure at the subducted plate interface. Earth Planet. Sci. Lett. 482, 33-43. https://doi.org/10.1016/j.epsl.2017.10.044.

Tamblyn, R., Hand, M., Zack, T., Kelsey, D., Morrissey, L., Pabst, S., Savov, I., 2018. Metamorphic Conditions of Blueschist Erupted From Serpentinite Mud Volcanism in the Mariana Forearc (EGU2018-5816, Vienna)

Tan, Z., Agard, P., Gao, J., John, T., Li, J., Jiang, T., Bayet, L., Wang, X., Zhang, X., 2017. P-Ttime-isotopic evolution of coesite-bearing eclogites: implications for exhumation processes in SW Tianshan. Lithos 278, 1-25. https://doi.org/10.1016/j. lithos.2017.01.010

Terabayashi, M., Maruyama, S., Liou, J.G., 1996. Thermobaric structure of the Franciscan complex in the Pacheco Pass region, Diablo Range, California. J. Geol. 104, 617-636.

Tichelaar, B., Ruff, L., 1993. Depth of seismic coupling along subduction zones. J. Geophys. Res.-Solid Earth 98, 2017-2037. https://doi.org/10.1029/92JB02045.

Toda, S., Stein, R.S., Kirby, S.H., Bozkurt, S.B., 2008. A slab fragment wedged under Tokyo and its tectonic and seismic implications. Nat. Geosci. 1, 771-776. https://doi.org/ 10.1038 /ngeo318

Tortorici, L., Catalano, S., Cirrincione, R., Tortorici, G., 2012. The Cretan ophiolite-bearing melange (Greece): a remnant of Alpine accretionary wedge. Tectonophysics 568 , 320-334. https://doi.org/10.1016/j.tecto.2011.08.022.

Trotet, F., Jolivet, L., Vidal, O., 2001a. Tectono-metamorphic evolution of Syros and Sifnos islands (Cyclades, Greece). Tectonophysics 338, 179-206. https://doi.org/10.1016/ S0040-1951(01)00138-X.

Trotet, F., Vidal, O., Jolivet, L., 2001b. Exhumation of Syros and Sifnos metamorphic rocks (Cyclades, Greece). New constraints on the P-T paths. Eur. J. Mineral. 13, 901-920. https://doi.org/10.1127/0935-1221/2001/0013/0901.

Trzcienski, W., 1988. Retrograde Eclogite from Mont-Albert, Gaspe, Quebec. Can. J. Earth Sci. 25, 30-37. https://doi.org/10.1139/e88-003.

Tsuji, T., Minato, S., Kamei, R., Tsuru, T., Kimura, G., 2017. 3D geometry of a plate boundary fault related to the 2016 Off-Mie earthquake in the Nankai subduction zone Japan. Earth Planet. Sci. Lett. 478, 234-244. https://doi.org/10.1016/j. epsl.2017.08.041.

Tsujimori, T., Ernst, W.G., 2014. Lawsonite blueschists and lawsonite eclogites as proxies for palaeo-subduction zone processes: a review. J. Metamorph. Geol. 32, 437-454. https://doi.org/10.1111/jmg.12057.

Tsujimori, T., Matsumoto, K., Wakabayashi, J., Liou, J.G., 2006a. Franciscan eclogite revisited: Reevaluation of the P-T evolution of tectonic blocks from Tiburon
Peninsula, California, USA. Mineral. Petrol. 88, 243-267. https://doi.org/10.1007/ s00710-006-0157-1.

Tsujimori, Tatsuki, Sisson, V.B., Liou, J.G., Harlow, G.E., Sorensen, S.S., 2006b. Very-lowtemperature record of the subduction process: a review of worldwide lawsonite eclogites. Lithos 92, 609-624. https://doi.org/10.1016/j.lithos.2006.03.054.

Uchida, N., Nakajima, J., Hasegawa, A., Matsuzawa, T., 2009. What controls interplate coupling? Evidence for abrupt change in coupling across a border between two overlying plates in the NEJapan subduction zone. Earth Planet. Sci. Lett. 283, 111-121. https:// doi.org/10.1016/j.epsl.2009.04.003.

Ulmer, P., Trommsdorff, V., 1995a. Serpentine stability to mantle depths and subductionrelated magmatism. Science 268, 858-861. https://doi.org/10.1126/ science.268.5212.858.

Ukar, E., Cloos, M., 2014. Low-temperatureblueschist-facies mafic blocks in the Franciscan melange, San Simeon, California: field relations, petrology, and counterclockwise P-T paths. Geol. Soc. Am. Bull. 126, 831-856. https://doi.org/10.1130/B30876.1.

Ukar, E., Cloos, M., Vasconcelos, P., 2012. First Ar-40-Ar-39 Ages from Low-T Mafic Blueschist Blocks in a Franciscan Melange near San Simeon: implications for Initiation of Subduction. J. Geol. 120, 543-556. https://doi.org/10.1086/666745.

Ulmer, P., Trommsdorff, V., 1995b. Serpentine stability to mantle depths and subductionrelated magmatism. Science 268, 858-861. https://doi.org/10.1126/ science.268.5212.858.

van Dinther, Y., Gerya, T.V., Dalguer, L.A., Mai, P.M., Morra, G., Giardini, D., 2013. The seismic cycle at subduction thrusts: Insights from seismo-thermo-mechanical models. J. Geophys. Res. Solid Earth 118, 6183-6202.

van Hinsbergen, D.J., Steinberger, B., Doubrovine, P.V., Gassmöller, R., 2011. Acceleration and deceleration of India-Asia convergence since the Cretaceous: Roles of mantle plumes and continental collision. Journal of Geophysical Research: Solid Earth 116 (B6)

van Hinsbergen, D.J.., Peters, K., Maffione, M., Spakman, W., Guilmette, C., Thieulot, C., Plumper, O., Gurer, D., Brouwer, F.M., Aldanmaz, E., Kaymakci, N., 2015. Dynamics of intraoceanic subduction initiation: 2. Suprasubduction zone ophiolite formation and metamorphic sole exhumation in context of absolute plate motions. Geochem. Geophys. Geosyst. 16, 1771-1785. https://doi.org/10.1002/2015GC005745.

van Keken, P.E., Hacker, B.R., Syracuse, E.M., Abers, G.A., 2011. Subduction factory: 4. Depth-dependent flux of H2O from subducting slabs worldwide. J. Geophys. Res. Solid Earth 116. https://doi.org/10.1029/2010JB007922.

van Keken, P.E., Kita, S., Nakajima, J., 2012. Thermal structure and intermediate-depth seismicity in the Tohoku-Hokkaido subduction zones. Solid Earth 3, 355-364. https://doi.org/10.5194/se-3-355-2012.

van Keken, P.E., Wada, I., Abers, G.A., Hacker, B.R., Wang, K., 2018. Mafic high-pressure rocks are preferentially exhumed from warm subduction settings. Geochem. Geophys. Geosyst. https://doi.org/10.1029/2018GC007624.

van Rijsingen, E., Lallemand, S., Peyret, M., Arcay, D., Heuret, A., Funiciello, F., Corbi, F., 2018. How subduction interface roughness influences the occurrence of large interplate earthquakes. Geochem. Geophys. Geosyst. 19 (8), 2342-2370.

Vannucchi, P., Morgan, J.P., Silver, E.A., Kluesner, J.W., 2016. Origin and dynamics of depositionary subduction margins. Geochem. Geophys. Geosyst. 17, 1966-1974. https://doi.org/10.1002/2016GC006259.

Vannucchi, P., Remitti, F., Bettelli, G., 2008. Geological record of fluid flow and seismogenesis along an erosive subducting plate boundary. Nature 451, 699-703.

Vannucchi, P., Remitti, F., Phipps-Morgan, J., Bettelli, G., 2009. Aseismic-Seismic transition and fluid regime along subduction plate boundaries and a fossil example from the Northern Apennines of Italy. Fault-Zone Properties and Earthquake Rupture Dynamics. Elsevier Academic Press Inc, San Diego, pp. 37-68.

Vannucchi, P., Sage, F., Phipps Morgan, J., Remitti, F., Collot, J.-Y., 2012. Toward a dynamic concept of the subduction channel at erosive convergent margins with implications for interplate material transfer. Geochem. Geophys. Geosyst. 13, Q02003. https:// doi.org/10.1029/2011GC003846.

Vannucchi, P., Spagnuolo, E., Aretusini, S., Di Toro, G., Ujiie, K., Tsutsumi, A., Nielsen, S., 2017. Past seismic slip-to-the-trench recorded in Central America megathrust. Nat. Geosci. 10, 935-940. https://doi.org/10.1038/s41561-017-0013-4.

Vaughan, A.P., Scarrow, J.H., 2003. Ophiolite obduction pulses as a proxy indicator of superplume events? Earth Planet. Sci. Lett. 213 (3-4), 407-416.

Vitale-Brovarone, A.V., Agard, P., 2013. True metamorphic isograds or tectonically sliced metamorphic sequence? New high-spatial resolution petrological data for the New Caledonia case study. Contrib. Mineral. Petrol. 166, 451-469. https://doi.org/ 10.1007/s00410-013-0885-2.

Vitale-Brovarone, A.V., Agard, P., Monié, P., Chauvet, A., Rabaute, A., 2018. Tectonic and metamorphic architecture of the HP belt of New Caledonia. Earth-Sci. Rev. 178, 48-67. https://doi.org/10.1016/j.earscirev.2018.01.006.

Vitale-Brovarone, A.V., Beyssac, O., Malavieille, J., Molli, G., Beltrando, M., Compagnoni, R., 2013. Stacking and metamorphism of continuous segments of subducted lithosphere in a high-pressure wedge: the example of Alpine Corsica (France). Earth-Sci. Rev. 116, 35-56. https://doi.org/10.1016/j.earscirev.2012.10.003.

Vitale-Brovarone, A.V., Picatto, M., Beyssac, O., Lagabrielle, Y. Castelli, D., 2014. The blueschist-eclogite transition in the Alpine chain: P-T paths and the role of slowspreading extensional structures in the evolution of HP-LT mountain belts. Tectonophysics 615, 96-121. https://doi.org/10.1016/j.tecto.2014.01.001.

Vogt, K., Gerya, T.V., 2014a. From oceanic plateaus to allochthonous terranes: Numerical modelling. Gondwana Res. 25, 494-508. https://doi.org/10.1016/j.gr.2012.11.002.

Vogt, K., Gerya, T., 2014b. Deep plate serpentinization triggers skinning of subducting slabs. Geology 42, 723-726. https://doi.org/10.1130/G35565.1.

von Huene, R., Scholl, D., 1991. Observations at convergent margins concerning sediment subduction, subduction erosion, and the growth of continental-crust. Rev. Geophys. 29, 279-316. https://doi.org/10.1029/91RG00969. 
Wada, I., Wang, K., 2009. Comwmon depth of slab-mantle decoupling: reconciling diversity and uniformity of subduction zones. Geochem. Geophys. Geosyst. 10. https://doi. org/10.1029/2009GC002570.

Wakabayashi, J., 2017. Structural context and variation of ocean plate stratigraphy, Franciscan complex, California: insight into mélange origins and subduction-accretion processes. Prog. Earth Planet. Sci. 4, 18. https://doi.org/10.1186/s40645-017-0132-y.

Wakabayashi, J., 2015. Anatomy of a subduction complex: architecture of the Franciscan complex, California, at multiple length and time scales. Int. Geol. Rev. 57, 669-746. https://doi.org/10.1080/00206814.2014.998728.

Wakabayashi, J., 2012. Subducted sedimentary serpentinite mélanges: record of multiple burial-exhumation cycles and subduction erosion. Tectonophys. Chaos Geodyn. 568569, 230-247. https://doi.org/10.1016/j.tecto.2011.11.006.

Wakabayashi, J., 1990. Counterclockwise P-T-T paths from amphibolites, Franciscan complex, California - relics from the early stages of Subduction Zone Metamorphism. J. Geol. 98, 657-680. https://doi.org/10.1086/629432.

Wakabayashi, J., Dilek, Y., 2000. Spatial and temporal relationships between ophiolites and their metamorphic soles: a test of models of forearc ophiolite genesis. In: Dilek, Y., Moores, E.M., Elthon, D., Nicolas, A. (Eds.), Ophiolites and Oceanic Crust: New Insights from Field Studies and Ocean Drilling Program. Geological Soc Amer Inc, Boulder, pp. 53-64

Wakabayashi, J., 2011. Mélanges of the Franciscan Complex, California: Diverse structural settings, evidence for sedimentary mixing, and their connection to subduction processes. In: Wakabayashi, Y., Dilek, Y. (Eds.), Mélanges: Processes of Formation and Societal Signifi cance. Geological Society of America Special, Paper 480, pp. 117-141 https://doi.org/10.1130/2011.2480(05).

Wakabayashi, J., Rowe, C.D., 2015. Whither the megathrust? Localization of large-scale subduction slip along the contact of a mélange. Int. Geol. Rev. 57, 854-870. https:// doi.org/10.1080/00206814.2015.1020453.

Wakabayashi, J., Tsujimori, T., Ogawa, Y., Shervais, J., 2015. Convergent plate margin processes and their rock record. Int. Geol. Rev. 57. https://doi.org/10.1080/ 00206814.2015.1026415 (v-ix)

Wakita, K., 2012. Mappable features of mélanges derived from Ocean Plate Stratigraphy in the Jurassic accretionary complexes of Mino and Chichibu terranes in Southwest Japan. Tectonophys. Chaos Geodyn. 568-569, 74-85. https://doi.org/10.1016/j. tecto.2011.10.019.

Wallace, L.M., Fagereng, Å., Ellis, S., 2012. Upper plate tectonic stress state may influence interseismic coupling on subduction megathrusts. Geology 40, 895-898. https://doi. org/10.1130/G33373.1.

Wallace, L.M., Reyners, M., Cochran, U., Bannister, S., Barnes, P.M., Berryman, K., Downes, G., Eberhart-Phillips, D., Fagereng, A., Ellis, S., Nicol, A., McCaffrey, R., Beavan, R.J. Henrys, S., Sutherland, R., Barker, D.H.N., Litchfield, N., Townend, J., Robinson, R., Bell, R., Wilson, K., Power, W., 2009. Characterizing the seismogenic zone of a major plate boundary subduction thrust: Hikurangi margin, New Zealand. Geochem. Geophys. Geosyst. 10, Q10006. https://doi.org/10.1029/2009GC002610.

Wallis, S., 1998. Exhuming the Sambagawa metamorphic belt: the importance of tectonic discontinuities. J. Metamorph. Geol. 16, 83-95. https://doi.org/10.1111/j.15251314.1998.00072.x

Wallis, S.R., Anczkiewicz, R., Endo, S., Aoya, M., Platt, J.P., Thirlwall, M., Hirata, T., 2009. Plate movements, ductile deformation and geochronology of the Sambagawa belt, SWJapan: tectonic significance of 89-88 Ma Lu-Hf eclogite ages. J. Metamorph. Geol. 27, 93-105. https://doi.org/10.1111/j.1525-1314.2008.00806.x.

Wang, K., Bilek, S.L., 2011. Do subducting seamounts generate or stop large earthquakes? Geology 39, 819-822.

Warren, C.J., 2013. Exhumation of (ultra-)high-pressure terranes: concepts and mechanisms. Solid Earth 4, 75-92. https://doi.org/10.5194/se-4-75-2013.

Wassmann, S., Stoeckhert, B., 2013. Rheology of the plate interface - Dissolution precipitation creep in high pressure metamorphic rocks. Tectonophysics 608, 1-29. https:// doi.org/10.1016/j.tecto.2013.09.030.

Wassmann, S., Stoeckhert, B., 2012. Matrix deformation mechanisms in HP-LT tectonic melanges - microstructural record of jadeite blueschist from the Franciscan complex, California. Tectonophysics 568, 135-153. https://doi.org/10.1016/j.tecto.2012.01.009.

Wassmann, S., Stoeckhert, B., Trepmann, C.A., 2011. Dissolution precipitation creep versus crystalline plasticity in high-pressure metamorphic serpentinites. In: Prior, D.J.,
Rutter, E.H., Tatham, D.J. (Eds.), Deformation Mechanisms, Rheology and Tectonics: Microstructures, Mechanics and Anisotropy. Geological Soc Publishing House, Bath, pp. 129-149.

Webber, S., Ellis, S., Fagereng, A., 2018. "Virtual shear box" experiments of stress and slip cycling within a subduction interface melange. Earth Planet. Sci. Lett. 488, 27-35. https://doi.org/10.1016/j.epsl.2018.01.035.

Wheeler, J., 1992. Importance of pressure solution and coble creep in the deformation of polymineralic rocks. J. Geophys. Res.-Solid Earth 97, 4579-4586. https://doi.org/ 10.1029/91JB02476.

Whitney, D.L., Teyssier, C., Seaton, N.C.A., Fornash, K.F., 2014. Petrofabrics of high-pressure rocks exhumed at the slab-mantle interface from the "point of no return" in a subduction zone (Sivrihisar, Turkey). Tectonics 33, 2315-2341. https://doi.org/10.1002/ 2014 TC003677.

Will, T., Okrusch, M., Schmadicke, E., Chen, G.L., 1998. Phase relations in the greenschistblueschist-amphibolite-eclogite facies in the system Na2O-CaO-FeO-MgO-Al2O3SiO2-H2O (INCFMASH), with application to metamorphic ROcks from Samos, Greece. Contrib. Mineral. Petrol. 132, 85-102. https://doi.org/10.1007/s004100050406.

Willner, A.P., 2005. Pressure-temperature evolution of a late Palaeozoic paired metamorphic belt in north-Central Chile (34 degrees-35 degrees 30'S). J. Petrol. 46, 1805-1833. https://doi.org/10.1093/petrology/egi035.

Willner, A.P., Glodny, J., Gerya, T.V., Godoy, E., Massonne, H., 2004. A counterclockwise PTt path of high-pressure/low-temperature rocks from the Coastal Cordillera accretionary complex of south-Central Chile: constraints for the earliest stage of subduction mass flow. Lithos 75, 283-310. https://doi.org/10.1016/j.lithos.2004.03.002.

Willner, A.P., Thomson, S.N., Kroner, A., Wartho, J.A., Wijbrans, J.R., Herve, F., 2005. Time markers for the evolution and exhumation history of a Late Palaeozoic paired metamorphic belt in north-Central Chile (34 degrees-35 degrees 30' S). J. Petrol. 46, 1835-1858. https://doi.org/10.1093/petrology/egi036.

Yamaguchi, A., Ujiie, K., Nakai, S., Kimura, G., 2012. Sources and physicochemical characteristics of fluids along a subduction-zone megathrust: a geochemical approach using syn-tectonic mineral veins in the Mugi mélange, Shimanto accretionary complex. Geochem. Geophys. Geosyst. 13. https://doi.org/10.1029/2012GC004137.

Yamato, P., Agard, P., Burov, E., Le Pourhiet, L., Jolivet, L., Tiberi, C., 2007. Burial and exhumation in a subduction wedge: Mutual constraints from thermomechanical modeling and natural P-T-t data (Schistes Lustres, western Alps). J. Geophys. Res.-Solid Earth 112, B07410. https://doi.org/10.1029/2006JB004441.

Yamato, P., Brun, J.P., 2017. Metamorphic record of catastrophic pressure drops in subduction zones. Nat. Geosci. 10, 46-50. https://doi.org/10.1038/NGEO2852.

Yamato, P., Burov, E., Agard, P., Le Pourhiet, L., Jolivet, L., 2008. HP-UHP exhumation during slow continental subduction: Self-consistent thermodynamically and thermomechanically coupled model with application to the Western Alps. Earth Planet. Sci. Lett. 271, 63-74. https://doi.org/10.1016/j.epsl.2008.03.049.

Zhang, J.X., Meng, F.C., Wan, Y.S., 2007. A cold early Palaeozoic subduction zone in the North Qilian Mountains. J. Metamorph. Geol. 25, 285-304. https://doi.org/10.1111/ j.1525-1314.2006.00689.X.

Zhang, X.-Z., Dong, Y.-S., Wang, Q., Dan, W., Zhang, C., Xu, W., Huang, M.-L., 2017. Metamorphic records for subduction erosion and subsequent underplating processes revealed by garnet-staurolite-muscovite schists in central Qiangtang, Tibet. Geochem. Geophys. Geosyst. 18, 266-279. https://doi.org/10.1002/2016GC006576.

Zhao, D., Wang, Z., Umino, N., Hasegawa, A., 2009. Mapping the mantle wedge and interplate thrust zone of the Northeast Japan arc. Tectonophysics 467, 89-106. https://doi.org/10.1016/j.tecto.2008.12.017.

Zheng, L., May, D., Gerya, T., Bostock, M., 2016. Fluid-assisted deformation of the subduction interface: coupled and decoupled regimes from 2-D hydromechanical modeling. J. Geophys. Res.-Solid Earth 121, 6132-6149. https://doi.org/10.1002/2016JB013102.

Zhou, J.-B., Wilde, S.A., Zhang, X.-Z., Zhao, G.-C., Zheng, C.-Q., Wang, Y.-J., Zhang, X.-H., 2009. The onset of Pacific margin accretion in NEChina: evidence from the Heilong jiang high-pressure metamorphic belt. Tectonophysics 478, 230-246. https://doi org/10.1016/j.tecto.2009.08.009. 